\title{
Tournaisian (Early Carboniferous/Mississippian) ammonoids from the Ma'der Basin (Anti-Atlas, Morocco)
}

\author{
Volker Ebbighausen ${ }^{*, 1}$ and Jürgen Bockwinkel ${ }^{* *, 2}$ \\ 1 Engstenberger Höhe 12, D-51519 Odenthal, Germany \\ 2 Dechant-Feinstraße 22, D-51375 Leverkusen, Germany
}

Received 17 December, 2006, accepted 8 February 2007

Published 1 August 2007

With 50 figures

Keywords: Ammonoids, biostratigraphy, Early Carboniferous, Anti-Atlas, Morocco.

\begin{abstract}
Three succeeding assemblages of Early Tournaisian (Mississippian) ammonoids are described from Fezzou (Ma'der) in the Anti-Atlas of Morocco; they are, in ascending order, composed of the following genera: (1) Gattendorfia-Eocanites Assemblage: Acutimitoceras, Costimitoceras, Imitoceras, Kornia, Gattendorfia, Kazakhstania, and Eocanites; (2) Gattendorfia-Kahlacanites Assemblage: Acutimitoceras, Hasselbachia, Gattendorfia, Becanites, and Kahlacanites; and (3) Goniocyclus-Protocanites Assemblage: Globimitoceras, Imitoceras, Gattendorfia, Goniocyclus, Eocanites, and Protocanites. The following taxa are newly described: Globimitoceras rharrhizense n. sp., Acutimitoceras sarahae n. sp., A. endoserpens n. sp., A. pentaconstrictum n. sp., Costimitoceras aitouamar n. sp., Hasselbachia arca n. sp., Kornia citrus n. gen. n. sp., Gattendorfia lhceni n. sp., and G. gisae n. sp.
\end{abstract}

Schlïsselwörter: Ammonoidea, Biostratigraphie, Unter-Karbon, Anti-Atlas, Marokko.

\section{Zusammenfassung}

Drei aufeinander folgende Vergesellschaftungen von Ammonoideen aus dem Tournaisium (Mississippium) werden von Fezzou (Ma'der) im Anti-Atlas von Marokko beschrieben; diese werden, in aufsteigender Reihenfolge, durch die folgenden Gattungen zusammen gesetzt: (1) Gattendorfia-Eocanites Assemblage: Acutimitoceras, Costimitoceras, Imitoceras, Kornia, Gattendorfia, Kazakhstania und Eocanites; (2) Gattendorfia-Kahlacanites Assemblage: Acutimitoceras, Hasselbachia, Gattendorfia, Becanites und Kahlacanites; und (3) Goniocyclus-Protocanites Assemblage: Globimitoceras, Imitoceras, Gattendorfia, Goniocyclus, Eocanites und Protocanites. Die folgenden Taxa werden neu beschrieben: Globimitoceras rharrhizense n. sp., Acutimitoceras sarahae n. sp., A. endoserpens n. sp., A. pentaconstrictum n. sp., Costimitoceras aitouamar n. sp., Hasselbachia arca n. sp., Kornia citrus n. gen. n. sp., Gattendorfia lhceni n. sp. und G. gisae n. sp.

\section{Introduction}

The area around Fezzou in the Ma'der region of the eastern Anti-Atlas in Morocco is well known for its rich Late Devonian ammonoid assemblages in limonitic preservation (e.g. Petter 1959, 1960), with specimens contained in numerous collections worldwide. These faunas were the subjects of sev- eral research projects, and their succession is now rather precisely known (Korn 1999; Becker et al. 2002; Ebbighausen \& Korn 2007).

The occurrence of Carboniferous ammonoids in the Ma'der, particularly at the Aguelmous ridge immediately north-east of Fezzou has been known since the 1930's, when Clariond (1935) mentioned "Muensteroceras sp." and "Aganides sp." from a

\footnotetext{
* Corresponding author: e-mail: volker@vxr.de

** E-mail: jbockwinkel@t-ontline.de
} 
locality a few kilometres east of Fezzou and proclaimed a Tournaisian age for this record. This view was adopted in the Carte Géologique du Maroc 1:200,000 (mapsheet Todhra-Ma'der), published by the Service Géologique du Maroc (Destombes \& Hollard 1988), in which Tournaisian sedimentary rocks are shown as exposed in the Aguelmous Syncline. Though it has long been known that "Gattendorfia" and "Prionoceras subbilobatum" can be found in this area (Hollard 1958), there has been no extensive collection of ammonoid faunas. During several field excursions in the years 2003 to 2006, the Carboniferous ammonoids of the Aguelmous Syncline were extensively collected, and now more than 1,300 specimens from four horizons are available for study.

\section{The ammonoid-bearing section at Aguelmous}

The Aguelmous is located northeast of Fezzou in the eastern Anti-Atlas of Morocco (Fig. 1). In the literature and on local maps, the name Aguelmous is used for two slightly different topographic structures, i.e., (1) the entire area north-east of Fezzou, and (2) the ridge beginning directly behind the houses north-east of Fezzou and extending for approximately $16 \mathrm{~km}$ towards the north-east. This ridge forms the north-western flank of the Aguelmous Syncline and has a SW-NE axis, extending $18 \mathrm{~km}$, with an average width of $6 \mathrm{~km}$. Late Devonian and Early Carboniferous strata have an inclination of $10-15^{\circ}$ on both flanks of the syncline and show only little additional deformation. The section begins with fossil-rich Famennian claystones, followed by latest Devonian sandstones of the Aoufital Formation that form a striking topographic ridge (Aguelmous on the north-western flank, Rharrhiz and Rich el Mbidia on the southeastern flank). The depression in the centre of the syncline is composed of Early Carboniferous shales and thin sandstone beds.

Below the Aoufital sandstones, late Devonian grey shales with Wocklumeria-bearing assemblages (Ebbighausen \& Korn 2007) are overlain by the two to three metres thick equivalent of the Hangenberg Black Shale, first discovered and stratigraphically dated by Korn (1999) in the area of Madène el Mrakib southeast of Fezzou. At this place, Korn discovered poorly preserved specimens of Acutimitoceras sp. from the basalmost sandstones of the Aoufital Formation.

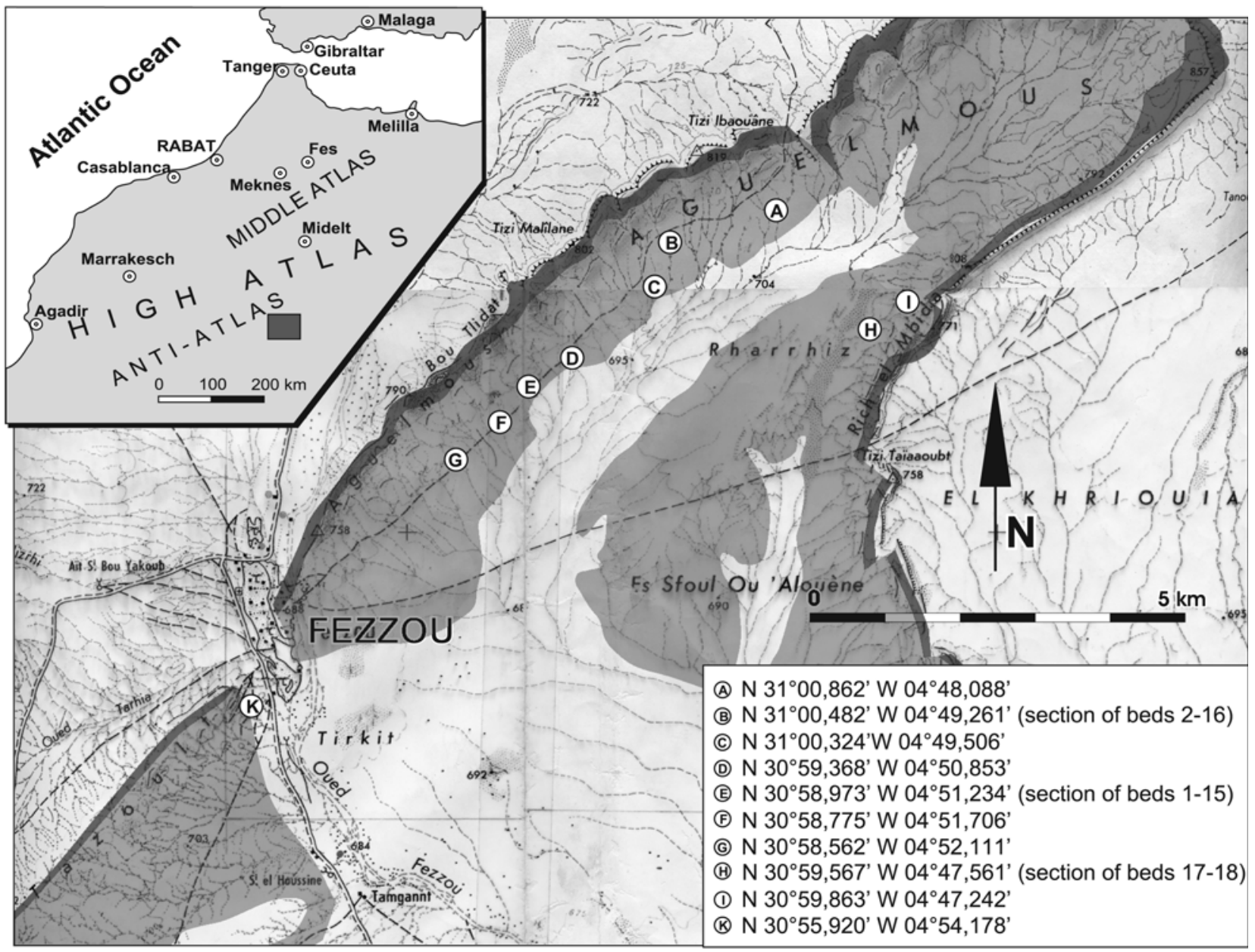

Fig. 1. The position of the Tournaisian ammonoid localities in the vicinity of Fezzou; Tizi Ibaouâne (A, B), Tizi Malilane (C), Bou Tlidat (D-G), Rich el Mbidia (H, I), Tazoult (K). 
The Early Carboniferous sediments of the Aguelmous are mainly composed of siliciclastics (shales, siltstones) with few carbonatic intercalations. The rock succession is deeply weathered and widely covered by debris. Sections can be measured only
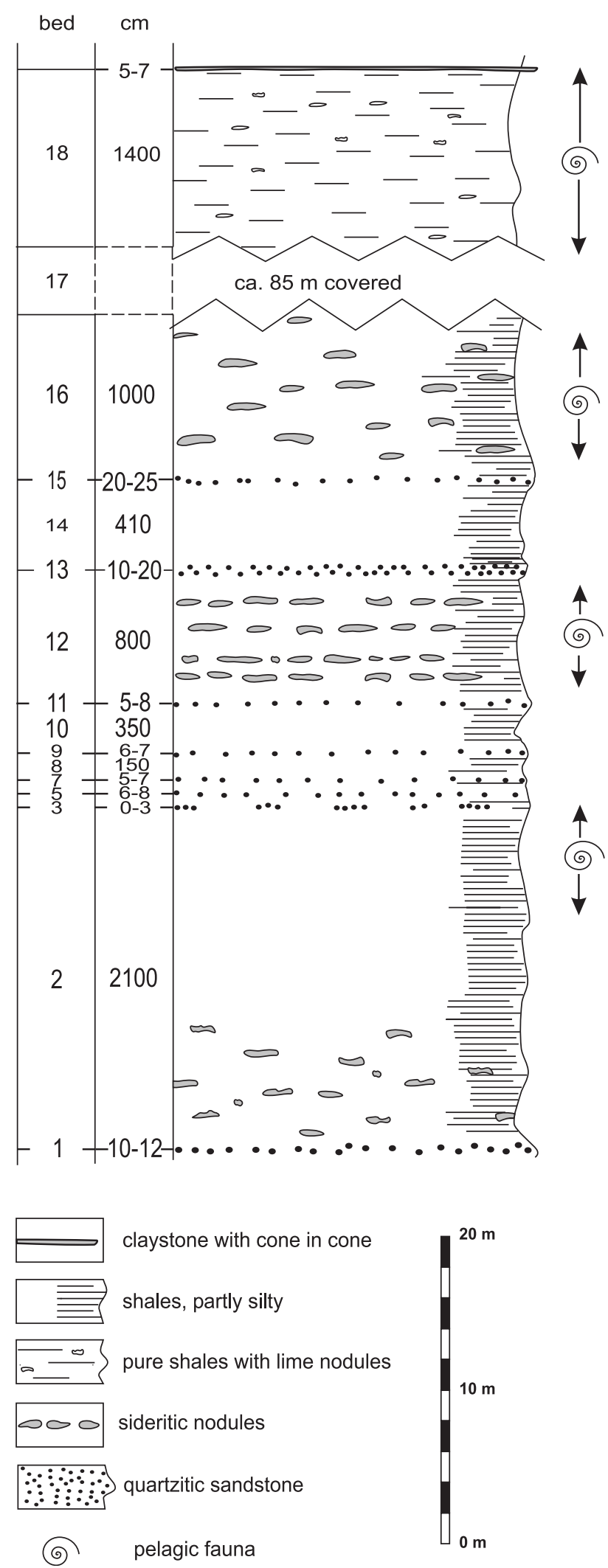

Fig. 2. Lithostratigraphy of the Late Devonian to Early Tournaisian beds at the Aguelmous, Ma'der, Morocco. in few areas, and therefore, a combination of several sections led to the synthesis given in Fig. 2. Lateral facies changes could not be observed in the study area. Although the faunas described in this study have been surface collected, a mixing of horizons can be ruled out. All assemblages are located in considerable distances from each other and are separated by sandstone ridges. A detailed description of the section was provided in an unpublished thesis by Kaiser (2005).

\section{Age of the ammonoid fauna}

Ammonoid faunas were recorded from beds 2, 12, 16, and 18 (Figs 2, 3). The ammonoid assemblages of beds 2 and 12 show close similarities with the fauna described by Bockwinkel \& Ebbighausen (2006) from Mfis in the southern Tafilalt of Morocco. The lack of index genera such as Paprothites and Pseudarietites, as characteristic for the Gattendorfia Limestone of the Rhenish Mountains (Vöhringer

Globimitoceras rharrhizense

Acutimitoceras hollardi

Acutimitoceras intermedium

Acutimitoceras occidentale

Acutimitoceras depressum

Acutimitoceras sarahae

Acutimitoceras mfisense

Acutimitoceras endoserpens

Acutimitoceras algeriense

Acutimitoceras sp. A

Acutimitoceras posterum

Acutimitoceras pentaconstrictum

Costimitoceras aitouamar

Hasselbachia gourara

Hasselbachia arca

Hasselbachia sp.

Kornia citrus

Imitoceras oxydentale

Imitoceras sp.

Gattendorfia jacquelinae

Gattendorfia debouaaensis

Gattendorfia Ihceni

Gattendorfia gisae

Gattendorfia sp.

Kazakhstania evoluta

Kazakhstania nitida

Goniocyclus elatrous

Eocanites simplex

Eocanites sp.

Becanites sp.

Kahlacanites mariae

Kahlacanites meyendorffi

Protocanites hollardi

Gen. indet. $1 \mathrm{sp}$. indet

Gen. indet. $2 \mathrm{sp}$. indet

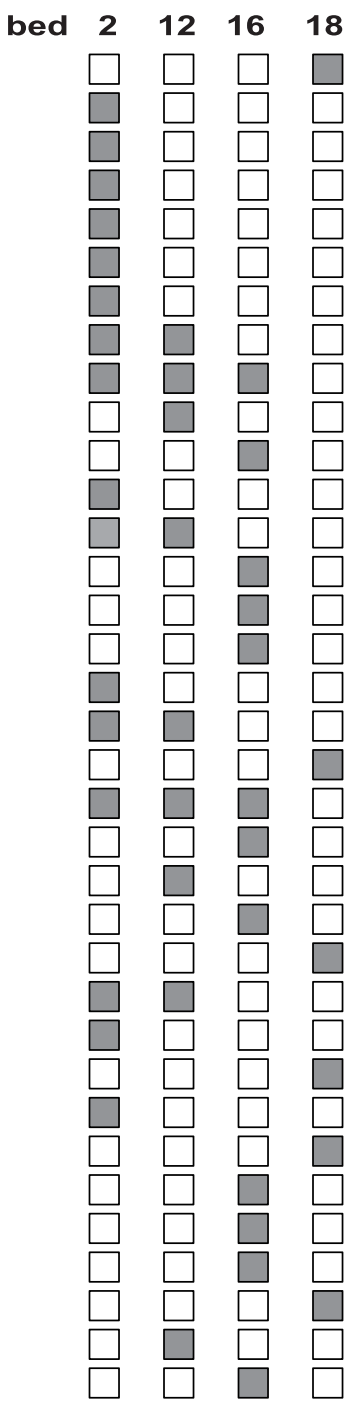

Fig. 3. Distribution of the ammonoid species in the Aguelmous sections. 


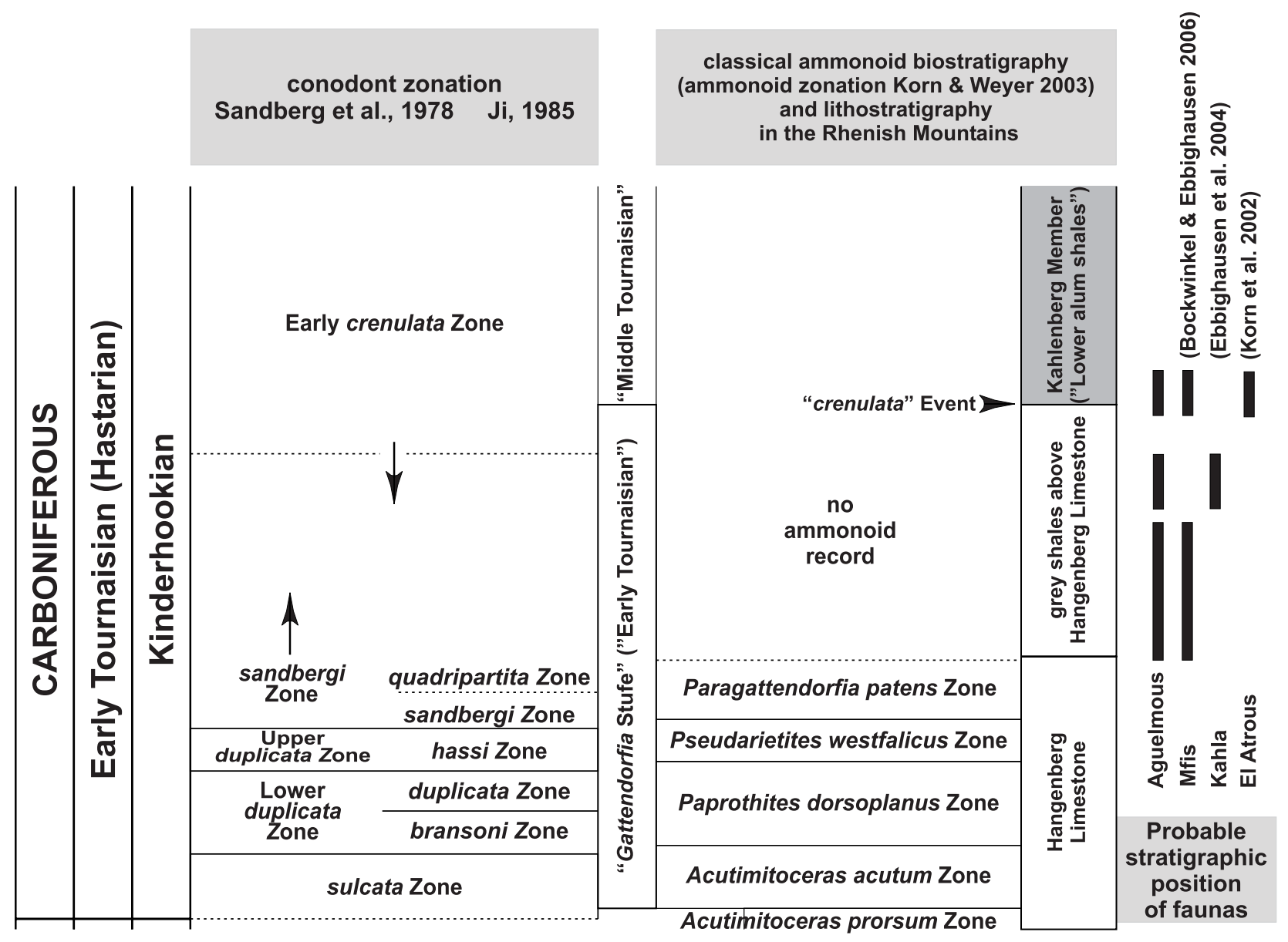

Fig. 4. Chronostratigraphy, ammonoid and conodont zonations in the northern Rhenish Mountains, after Korn \& Weyer (2003).

1960) and South China (Ruan 1981), but the presence of advanced forms such as Imitoceras speak for a position above the classical Gattendorfia Stufe (Fig. 4). Korn et al. (2007) place this fauna in the Gattendorfia-Eocanites Assemblage of the North African Carboniferous ammonoid succession. Kaiser (2005) correlated this fauna with the lowest Carboniferous Acutimitoceras acutum Zone, based on the occurrence of "Stockumites" (= Acutimitoceras) and the "Gattendorfia molaris Group" (= Weyerella), confirmed by Gattendorfia and Eocanites. However, Weyerella has not been recorded from Aguelmous, and the other elements do not exclude a younger stratigraphic assignment.

Bed 16 is dominated by the genera Gattendorfia, Kahlacanites, and Hasselbachia. A very similar fauna is known from the Grès supérieur de Kahla from the Gara el Kahla near Timimoun in north-western Algeria (Ebbighausen et al. 2004). This fauna is placed in the Gattendorfia-Kahlacanites Assemblage (Korn et al. 2007).

The poorly preserved fauna from bed 18 is almost identical with the fauna known from a locality $75 \mathrm{~km}$ east of the Aguelmous in the Amessoui Syncline (Korn et al. 2002). It belongs to the GoniocyclusProtocanites Assemblage (Korn et al. 2007).

\section{Palaeontological descriptions of the ammonoids}

Abbreviations used in the text are $\mathrm{dm}$ - conch diameter, ww - whorl width, uw - umbilical width, wh - whorl height, ah - apertural height, IZR - imprint zone rate, calculated (wh-ah)/wh (see Korn \& Klug 2002), and WER - whorl expansion rate, calculated $[\mathrm{dm} /(\mathrm{dm}-\mathrm{ah})]^{2}$ (Fig. 5A). Described and illustrated specimens are housed in the collection of the Museum für Naturkunde der Humboldt-Universität zu Berlin, with the catalogue numbers MB.C.10151-MB.C.10241. The terminology of the suture line (Fig. 5B) follows Korn et al. (2003). Synonymy lists were partly obtained from the database GONIAT, version 2.60 (Korn \& Kullmann 1996).

Order Goniatitida Hyatt, 1884

Suborder Tornoceratina Wedekind, 1918

Superfamily Prionoceratoidea Hyatt, 1884

Family Prionoceratidae Hyatt, 1884

Subfamily Prionoceratinae Hyatt, 1884

\section{Globimitoceras Korn, 1992}

\section{Globimitoceras rharrhizense n. sp.}

Figs 6, 7

Derivation of name. After the Rharrhiz crest north-east of Fezzou.

Holotype. Specimen MB.C.10185.1; illustrated here in Fig. 6A. 

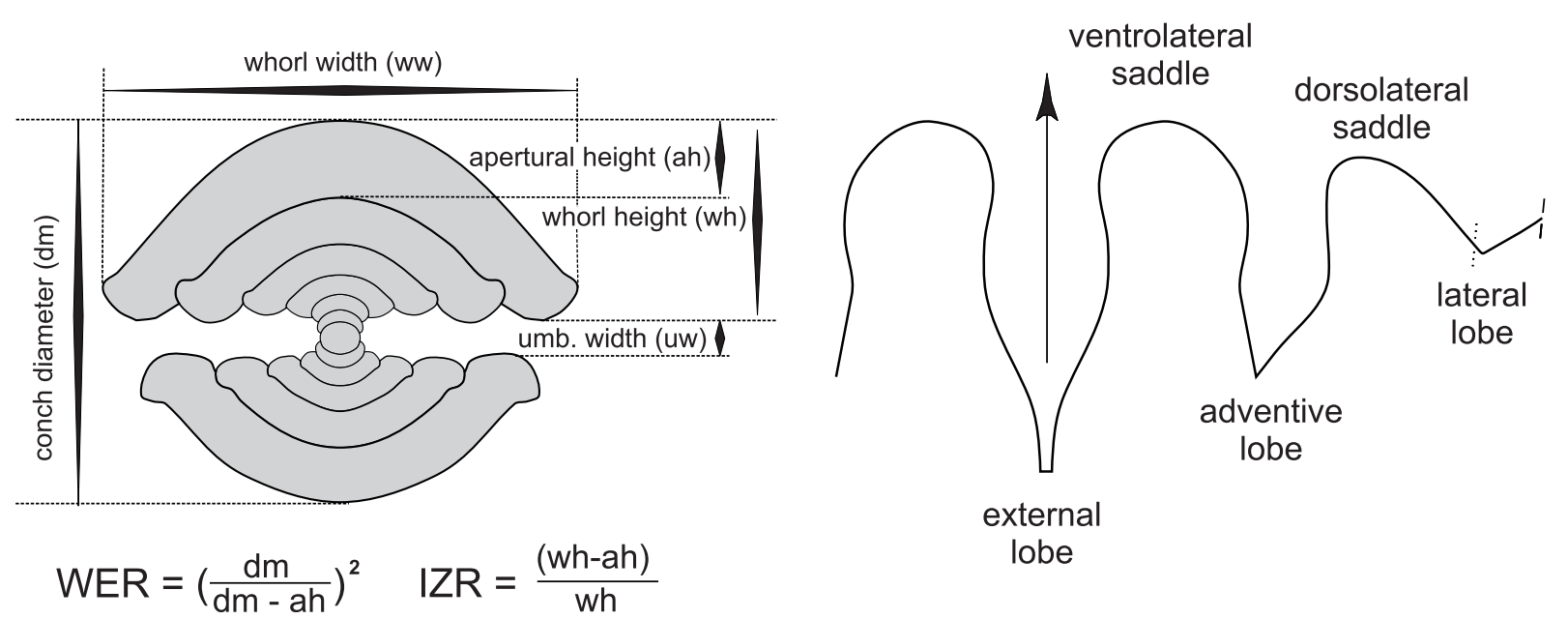

Fig. 5. Conch parameters, calculated ratios and rates; suture nomenclature of the investigated ammonoids, after Korn \& Klug (2002).
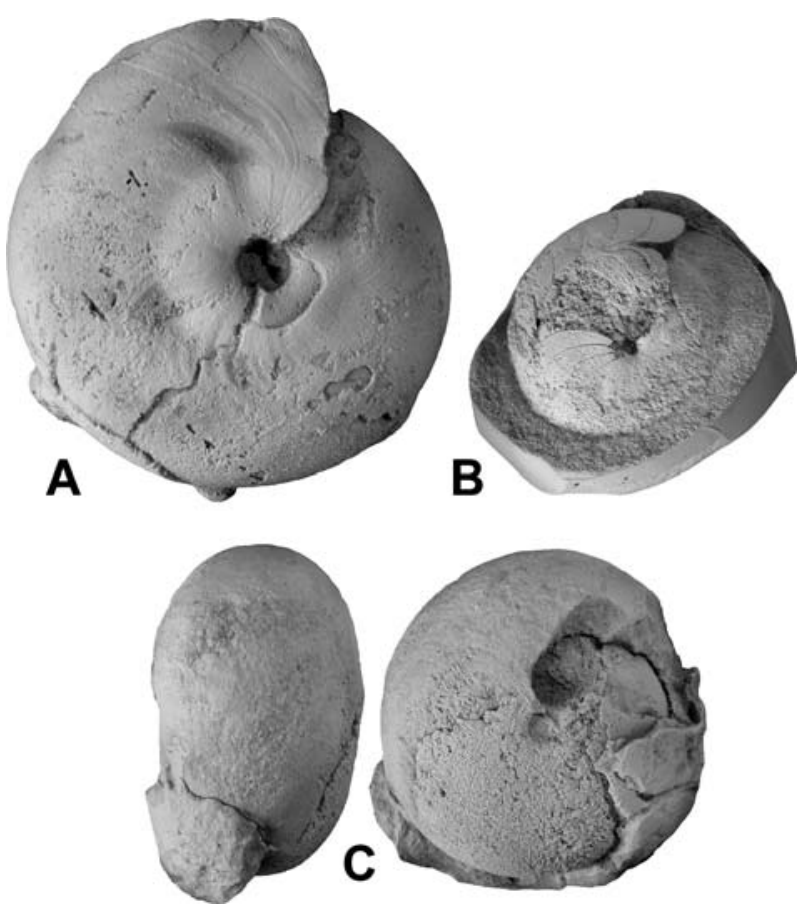

Fig. 6. Globimitoceras rharrhizense $\mathrm{n}$. $\mathrm{sp}$. from Rich el Mbidia, bed $18, \times 1$. A - Holotype MB.C.10185.1, lateral view,. B - Paratype MB.C.10185.2, latex cast, lateral view. C - Paratype MB.C.10185.4, ventral and lateral views.

Type locality and horizon. Rich el Mbidia at the Rharrhiz crest north-east of Fezzou (Ma'der, Anti-Atlas, Morocco); bed 18 (Middle Tournaisian).

Material. Rich el Mbidia (bed 18): 32 specimens.

Diagnosis. Species of Globimitoceras with globular conch at $5 \mathrm{~mm}$ conch diameter $(\mathrm{ww} / \mathrm{dm}=1.00)$, decreasing to a thickly pachyconic conch at $20 \mathrm{~mm} \mathrm{dm}(\mathrm{ww} / \mathrm{dm}=0.70-0.80)$. Umbilicus very narrow throughout ontogeny (uw $/ \mathrm{dm}=$ $0.15-0.20$ in juveniles; $0.10-0.15$ in the adult stage). Suture line with asymmetric, lanceolate and very narrow adventive lobe that is deeper than the external lobe. Ornament with fine, strongly convex growth lines; steinkern without constrictions. Umbilicus in the adult stage surrounded by a conspicuous pad.
Description. Paratype MB.C.10185.3 was sectioned and displays the conch ontogeny from 2 to $24 \mathrm{~mm}$ diameter (Fig. 7A). The conch has always a similar form lacking conspicuous changes of morphology, but is much wider in the juvenile stage $(\mathrm{ww} / \mathrm{dm}=1.20-1.30$ at $2-3 \mathrm{~mm} \mathrm{dm})$ and becomes continuously more slender $(\mathrm{ww} / \mathrm{dm}=0.70-0.80$ at $16-24 \mathrm{~mm} \mathrm{dm}$ ). The umbilicus becomes narrower during this interval; the uw/dm ratio decreases from almost 0.20 to 0.12 . All stages show a low aperture with a whorl expansion rate of about 1.50 . Holotype MB.C.10185.1 is an adult individual with $47 \mathrm{~mm}$ diameter. It shows the adult modification of the conch in possessing a conspicuous tab around the umbilicus (Fig. 6A). Close to the aperture, there is a short radial grooving visible, being backwardly bent. The growth lines of the specimen show a rather high dorsolateral projection and turn back to form a very deep ventral sinus.

Paratype MB.C.10185.5 is a specimen of the same size; it shows the characteristic umbilical pad, and also a deep grooving on the inner flank near the end of the last volution. Smaller specimens such as paratype MB.C.10185.4 (33 $\mathrm{mm} \mathrm{dm}$ ) do not show these adult modifications. They possess a pachyconic to globular conch with continuously rounded flanks. The suture line of paratype MB.C.10185.2 is characterised by a very narrow, lanceolate external and adventive lobe, respectively, and by very wide, broadly arched ventrolateral and dorsolateral saddles (Fig. 7B).

Discussion. It is not easy to attribute the new species to a distinct genus, but, according to the conch geometry and suture line, placement into Globimitoceras is most reasonable. The new species differs from the type species G. globiforme (Vöhringer, 1960) in the more slender conch shape in the adult stage and, in particular, in the presence of the umbilical pad. This character distinguishes G. rharrhizense n. sp. from all other Tournaisian ammonoids. 

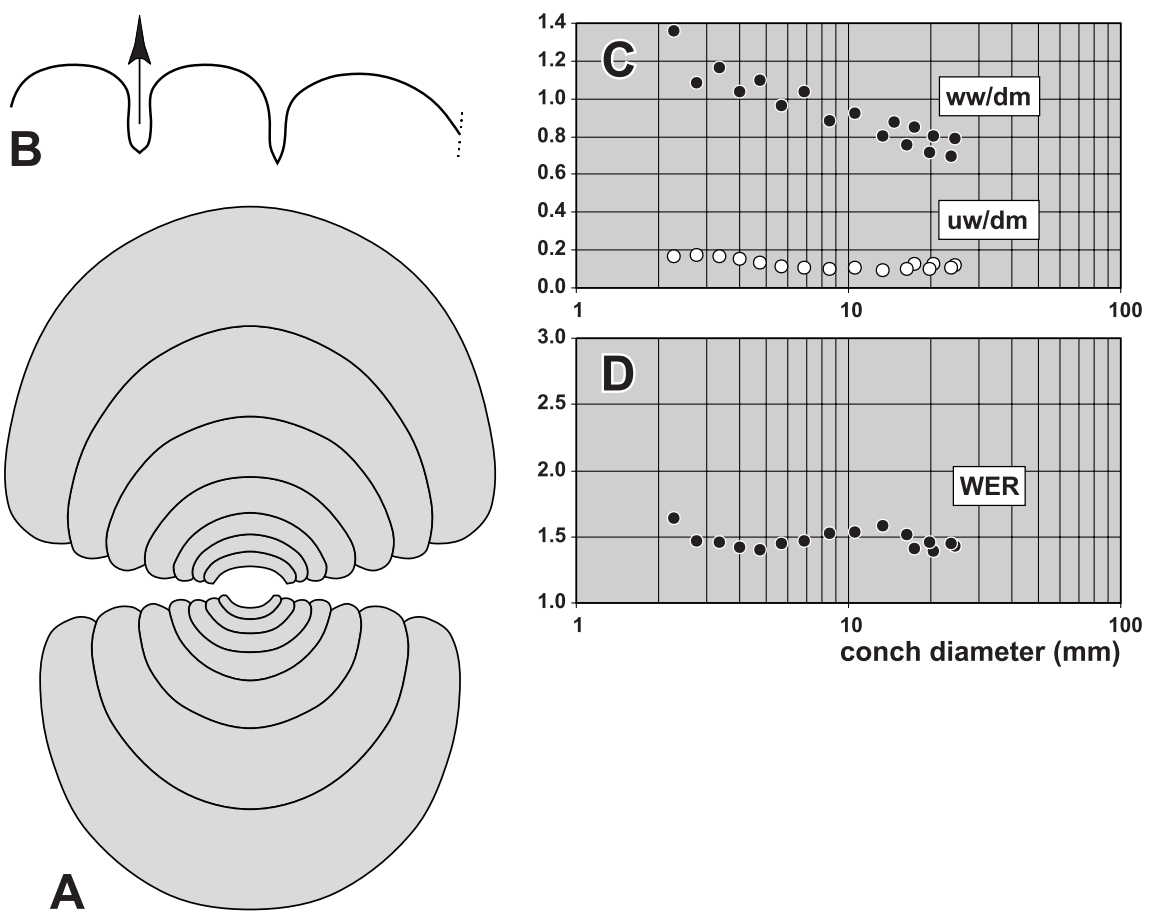

Fig. 7. Globimitoceras rharrhizense n. sp. from bed 18 of the Aguelmous. A - Cross section, specimen MB.C.10185.3; $\times 3$. B Suture line, specimen MB.C.10185.2, at $16.0 \mathrm{~mm}$ ww, $12.2 \mathrm{~mm}$ wh; $\times 2$. C - Ontogenetic development of the whorl width index $(w w / d m)$ and umbilical width index (uw/dm). D - Ontogenetic development of the whorl expansion rate (WER).
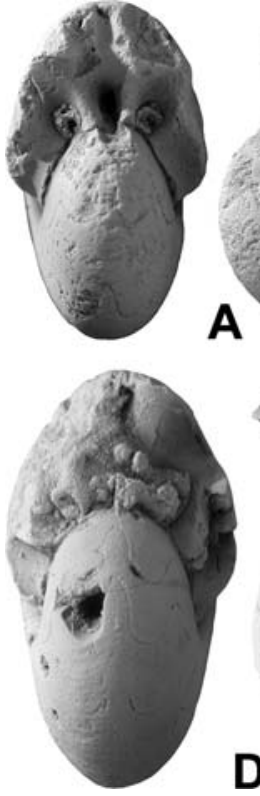

D
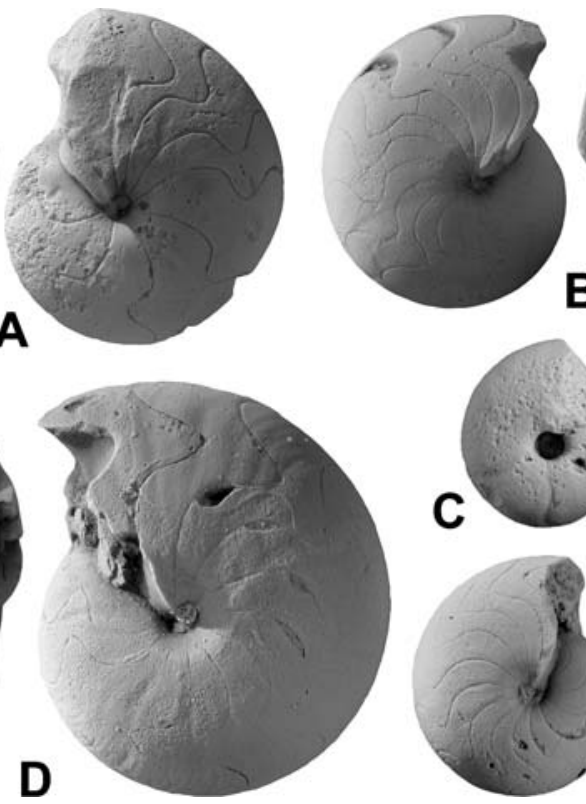

B
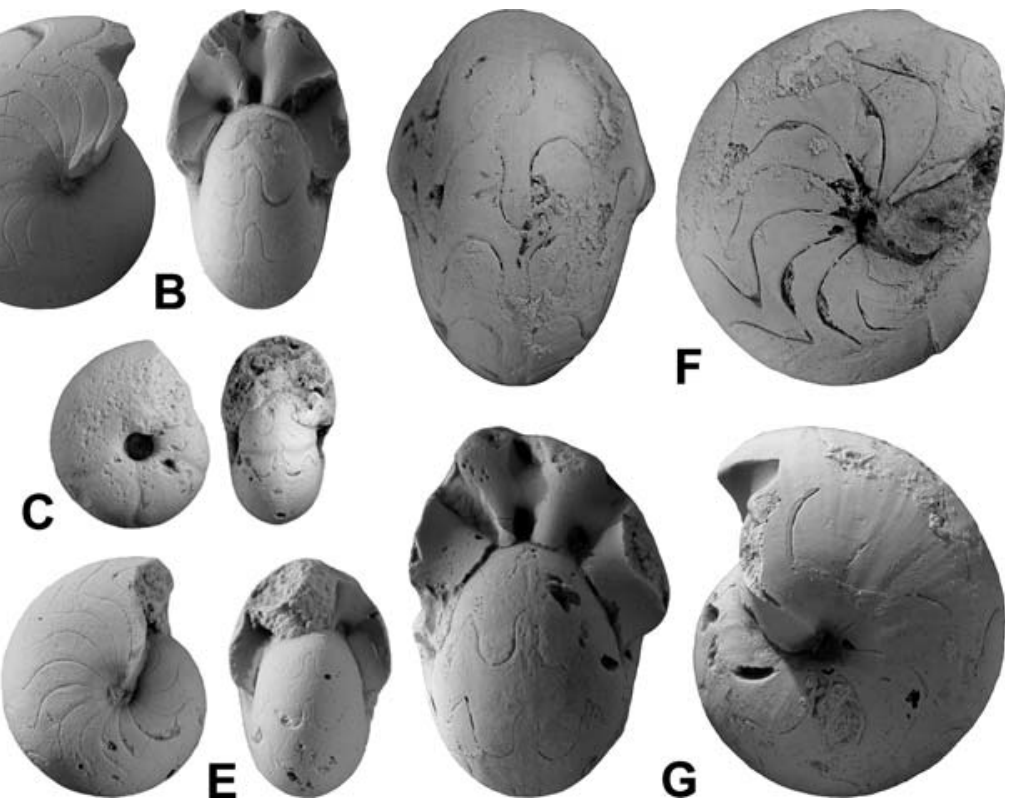

Fig. 8. Acutimitoceras from the Aguelmous near Fezzou. A - Acutimitoceras hollardi Bockwinkel \& Ebbighausen, 2006, specimen MB.C.10192.1, from Tazoult, bed 2, dorsal and lateral views, $\times 2.5$. B - Acutimitoceras hollardi Bockwinkel \& Ebbighausen, 2006, specimen MB.C.10192.2 from Tazoult, bed 2, lateral and dorsal views, $\times 2.5$. C - Acutimitoceras hollardi Bockwinkel \& Ebbighausen, 2006, specimen MB.C.10192.3 from Tazoult, bed 2, lateral and dorsal views, $\times 3$. D - Acutimitoceras occidentale Bockwinkel \& Ebbighausen, 2006, specimen MB.C.10196.1 from Tazoult, bed 2, dorsal and lateral views, $\times 2.5$. E - Acutimitoceras occidentale Bockwinkel \& Ebbighausen, 2006, specimen MB.C.10158.1 from Bou Tlidat, lateral and dorsal views, $\times 3$. F - Acutimitoceras intermedium (Schindewolf, 1923), specimen MB.C.10193.1, from Tazoult, bed 2, ventral and lateral views, $\times 2$. G - Acutimitoceras intermedium (Schindewolf, 1923), specimen MB.C.10155.1, from Bou Tlidat, bed 2, dorsal and lateral views, $\times 2.5$. 
Subfamily Acutimitoceratinae Korn, 1994

\section{Acutimitoceras Librovitch, 1957}

Type species. Imitoceras acutum Schindewolf, 1923.

\section{Acutimitoceras hollardi Bockwinkel \& Ebbighausen, 2006}

Figs $8 \mathrm{~A}-\mathrm{C}, 9$

* 2006 Acutimitoceras hollardi Bockwinkel \& Ebbighausen: 96, figs $11,12$.

Holotype. Specimen MB.C.3827.1.

Type locality and horizon. Northern slope of the Jebel Debouaâ east of Mfis (Anti-Atlas, Morocco); bed 9 (Early Tournaisian).

Material. Bou Tlidat (bed 2): 9 specimens, Tazoult (bed 2): 9 specimens, Tazoult (loose): 3 specimens.

Diagnosis. Species of Acutimitoceras with thickly discoidal conch $(\mathrm{ww} / \mathrm{dm}=0.55$ at $12 \mathrm{~mm} \mathrm{dm})$. Inner whorls up to $5 \mathrm{~mm}$ diameter with open umbilicus (uw/dm $=0.15-0.30$ ), umbilicus slightly open at $12 \mathrm{~mm}$ diameter. Aperture low in the juvenile stage but becoming higher during ontogeny; whorl expansion rate higher than 2.00 in stages larger than $10 \mathrm{~mm}$ diameter. Steinkern without or with weak constrictions. Suture line with narrow, lanceolate external lobe and Vshaped, very shallow, narrowly rounded adventive lobe.

Remarks. When erecting this peculiar species, Bockwinkel \& Ebbighausen (2006) had only two specimens. Now, more than 20 additional specimens are available, and the diagnosis is thus revised. In contrast to the original description, the new specimens such as MB.C.10192.2 (Fig. 8B) have feeble constrictions that extend convexly across the flank and turn back for a shallow ventral sinus. Furthermore, the specimens from Aguelmous show that the apertural height becomes more prominent in stages above $8 \mathrm{~mm} \mathrm{dm}$, and hence is characteristic for Acutimitoceras.
Acutimitoceras intermedium (Schindewolf, 1923)

Figs 8F, G, 10, 12A, B

* 1923 Imitoceras intermedium Schindewolf: 333, pl. 16: fig. 2.

2006 Acutimitoceras intermedium. - Bockwinkel \& Ebbighausen: 97, text-figs 13, 14 (for more synonymy).

Mat e ri a l. Bou Tlidat (bed 2): 264 specimens, Tazoult (bed 2): 14 specimens, Tazoult (loose): 26 specimens, Rich El Mbidia (bed 2): 5 specimens, Tizi Ibaouâne (bed 2); 9 specimens, Tizi Malilane (bed 2): 4 specimens.

Remarks. The new material allowed the preparation of a series of cross sections, from which the conch ontogeny from the initial stage up to $20 \mathrm{~mm}$ diameter can be investigated (Fig. 10A-C). Growth trajectories are characteristic for Acutimitoceras with striking ontogenetic changes.

\section{Acutimitoceras occidentale Bockwinkel \& Ebbighausen, 2006 \\ Figs $8 \mathrm{D}-\mathrm{E}, 11$}

* 2006 Acutimitoceras occidentale Bockwinkel \& Ebbighausen: 103, figs 19, 20.

Material. Bou Tlidat (bed 2): 17 specimens, Tazoult (bed 2): 26 specimens, Tazoult (loose): 28 specimens.

Remarks. The very close resemblance of the new material to the original Mfis material confirms the diagnosis given for that species by Bockwinkel \& Ebbighausen (2006).

\section{Acutimitoceras depressum (Vöhringer, 1960)}

Figs $12 \mathrm{C}, \mathrm{D}, 13$

1960 Imitoceras depressum Vöhringer: 130, pl. 3: fig. 5

1994 Acutimitoceras depressum. - Korn: 43, figs 44I, J, 45F, $\mathrm{G}, 47 \mathrm{C}, 48 \mathrm{E}$.

Material. Bou Tlidat (bed 2): 13 specimens, Tazoult (bed 2): 2 specimens, Tazoult (loose): 2 specimens, Tizi Ibaouâne (bed 2); 1 specimen.
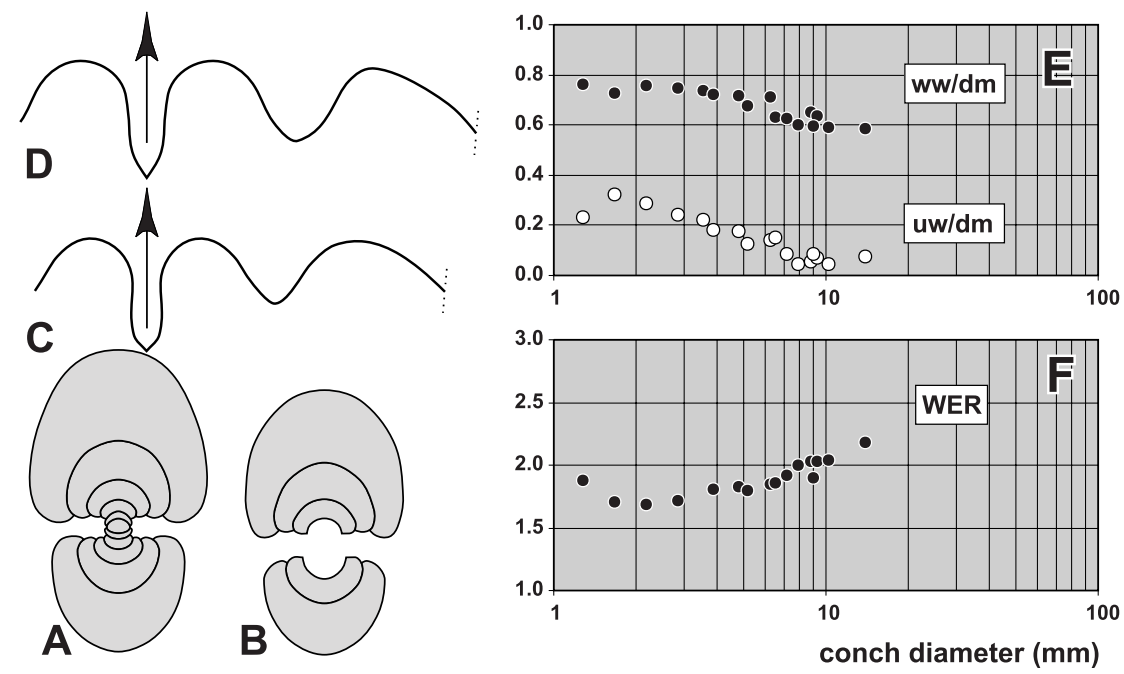

Fig. 9. Acutimitoceras hollardi Bockwinkel \& Ebbighausen, 2006 from bed 2 of the Aguelmous. A - Cross section, specimen MB.C.10192.4; $\times 3$. B - Cross section, specimen MB.C.10154.1; $\times 3$. C - Suture line (reversed), specimen MB.C.10154.2, at $4.6 \mathrm{~mm}$ ww, $3.9 \mathrm{~mm}$ wh; $\times 7$. D - Suture line (reversed), specimen MB.C.10154.3, at $7.3 \mathrm{~mm} \mathrm{dm}, 4.8 \mathrm{~mm}$ ww, $4.3 \mathrm{~mm}$ wh; $\times 7$. E - Ontogenetic development of the whorl width index $(\mathrm{ww} / \mathrm{dm})$ and umbilical width index (uw/dm). F - Ontogenetic development of the whorl expansion rate (WER) 


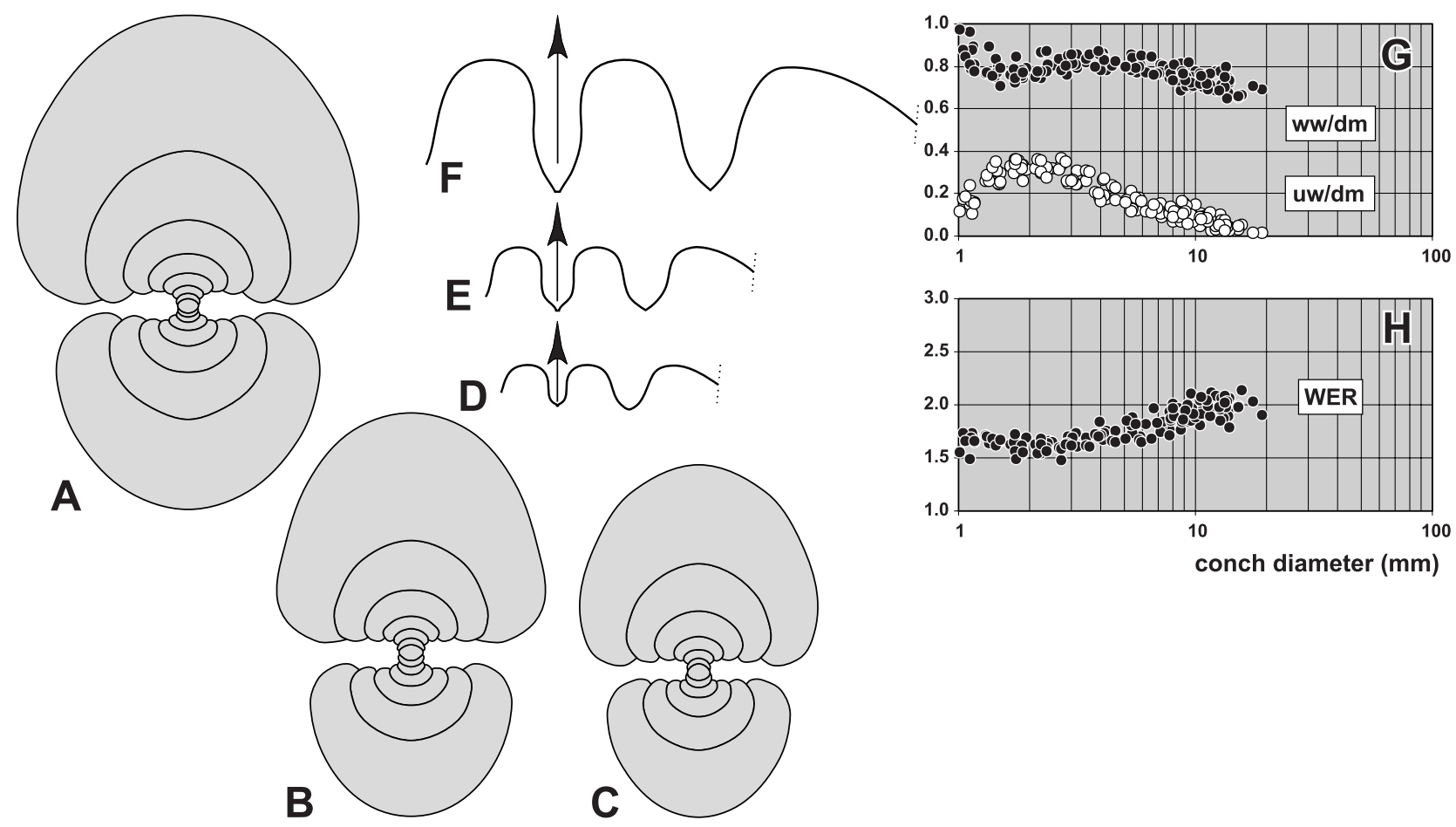

Fig. 10. Acutimitoceras intermedium (Schindewolf, 1923) from bed 2 of the Aguelmous. A - Cross section, specimen MB.C.10206.1; $\times 3$. B - Cross section, specimen MB.C.10155.4; ×3. C - Cross section, specimen MB.C.10216.1; $\times 3$. D - Suture line (reversed), specimen MB.C.10155.5, at $2.4 \mathrm{~mm}$ ww, $1.3 \mathrm{~mm}$ wh; $\times 10$. E - Suture line specimen MB.C.10155.6, at $5.1 \mathrm{~mm} \mathrm{dm}, 4.2 \mathrm{~mm}$ ww, $2.1 \mathrm{~mm}$ wh; $\times 7 . \mathbf{F}$ - Suture line, specimen MB.C.10155.4, at $10.8 \mathrm{~mm} \mathrm{dm}, 7.9 \mathrm{~mm}$ ww, $5.0 \mathrm{~mm}$ wh; $\times 6 . \mathbf{G}-$ Ontogenetic development of the whorl width index (ww/dm) and umbilical width index (uw/dm). H - Ontogenetic development of the whorl expansion rate (WER).

Diagnosis. Species of Acutimitoceras with thickly pachyconic conch $(\mathrm{ww} / \mathrm{dm}=0.70-0.85$ at $12 \mathrm{~mm} \mathrm{dm})$. Inner whorls up to $5 \mathrm{~mm}$ diameter with open umbilicus (uw/dm $=0.20-0.35$ ), umbilicus closed at $12 \mathrm{~mm}$ diameter. Aperture low in the juvenile stage and slowly becoming higher during ontogeny; whorl expansion rate higher $1.70-1.90$ in stages larger than $10 \mathrm{~mm}$ diameter. Steinkern without or with weak constrictions in the adult stage, shallow constrictions in juveniles. Suture line with lanceolate external lobe and V-shaped adventive lobe.
Description. The cross sections of the material shows a rather wide variability, particularly when the umbilical width is studied (Fig. 13). The conchs are widest umbilicate at $2-3 \mathrm{~mm} \mathrm{dm}$, where the $\mathrm{uw} / \mathrm{dm}$ ratio reaches a maximum of $0.30-0.40$. This ratio then becomes progressively smaller, and the umbilicus is almost closed at $12 \mathrm{~mm} \mathrm{dm}$. The conch width index is stable at $0.75-0.85$ between 3 and
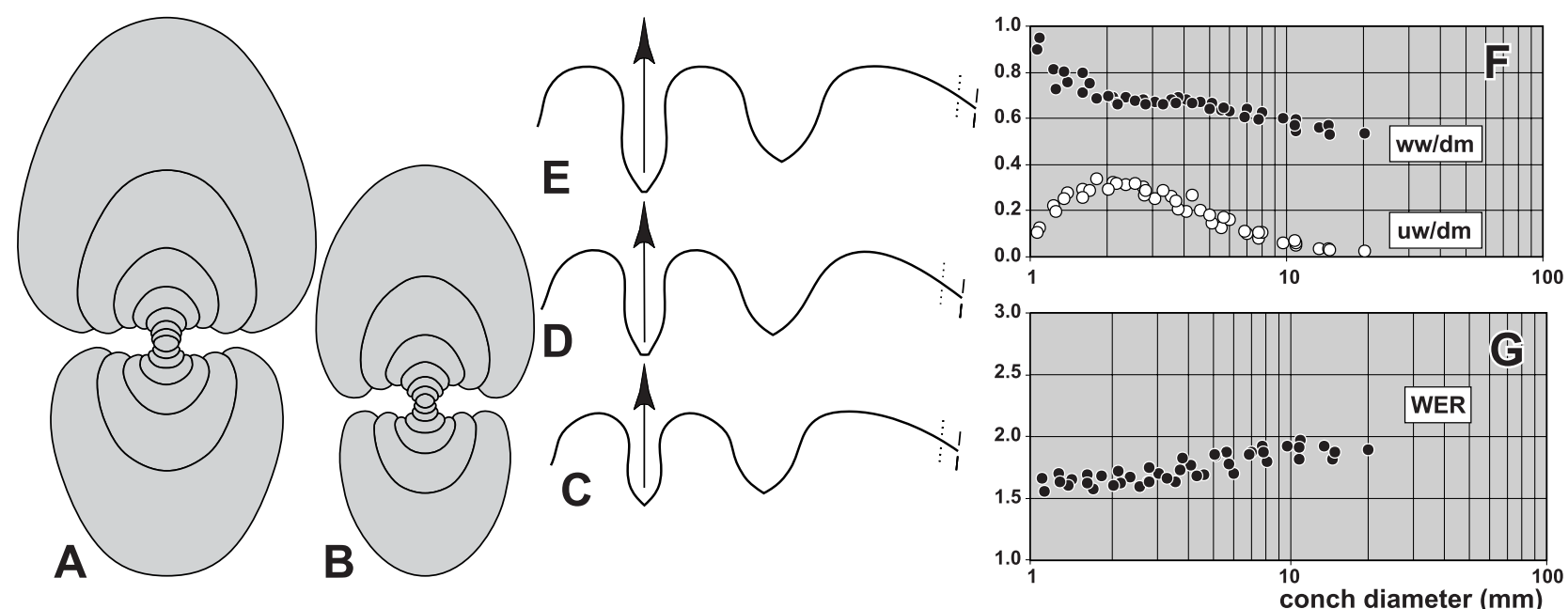

Fig. 11. Acutimitoceras occidentale Bockwinkel \& Ebbighausen, 2006 from bed 2 of the Aguelmous. A - Cross section, specimen MB.C.10196.2; ×3. B - Cross section, specimen MB.C.10196.3; $\times 3$. C - Suture line, specimen MB.C.10158.3, at 6.0 mm ww, $5.5 \mathrm{~mm}$ wh; $\times 5$. D - Suture line, specimen MB.C.10158.2, at $8.8 \mathrm{~mm} \mathrm{dm}, 6.3 \mathrm{~mm}$ ww, $4.6 \mathrm{~mm}$ wh; $\times 5$. E - Suture line, specimen MB.C.10158.4, at $6.8 \mathrm{~mm}$ ww, $6.4 \mathrm{~mm}$ wh; $\times 5$. F - Ontogenetic development of the whorl width index (ww/dm) and umbilical width index (uw/dm). G - Ontogenetic development of the whorl expansion rate (WER). 


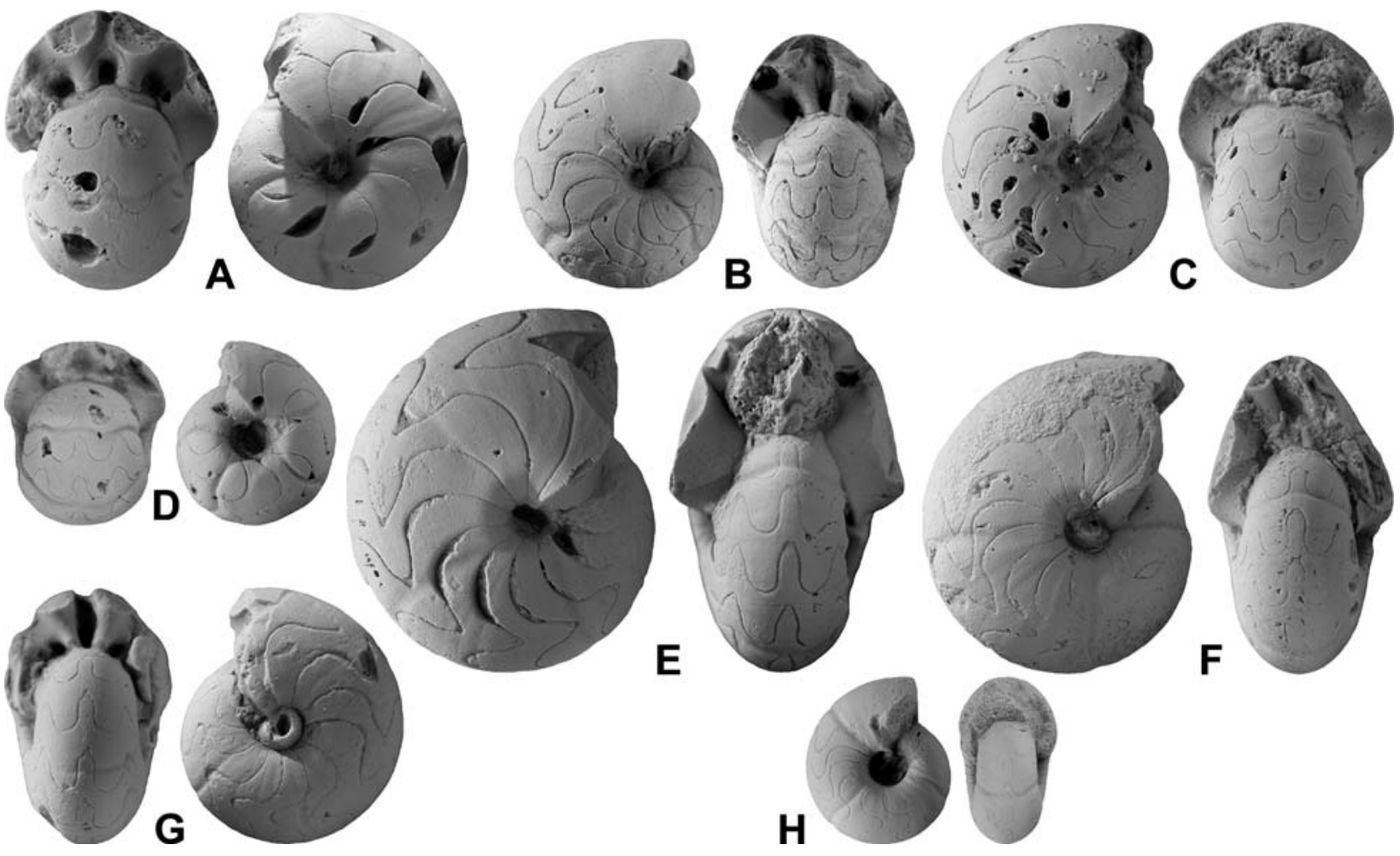

Fig. 12. Acutimitoceras from Bou Tlidat, bed 2, all $\times$ 3. A - Acutimitoceras intermedium (Schindewolf, 1923), specimen MB.C.10155.2, dorsal and lateral views. B - Acutimitoceras intermedium (Schindewolf, 1923), specimen MB.C.10155.3, lateral and dorsal views. C - Acutimitoceras depressum (Vöhringer, 1960), specimen MB.C.10152.2, lateral and dorsal views. D - Acutimitoceras depressum (Vöhringer, 1960), specimen MB.C.10152.1, dorsal and lateral views. E - Acutimitoceras sarahae n. sp. holotype MB.C.10156.1, lateral and dorsal views. F - Acutimitoceras sarahae n. sp. paratype MB.C.10156.2, lateral and dorsal views. G - Acutimitoceras sarahae n. sp. paratype MB.C.10156.3, dorsal and lateral views. H - Acutimitoceras sarahae n. sp. paratype MB.C.10156.4, lateral and dorsal views.

$10 \mathrm{~mm} \mathrm{dm}$. Between 2 and $12 \mathrm{~mm} \mathrm{dm}$, there is a continuous increase of the apertural height (WER increasing from 1.60 to 1.80 ).

Specimen MB.C.10152.2 is a characteristic specimen that has an $11 \mathrm{~mm}$ conch diameter, 12 chambers on the last volution and is fully septate (Fig. 12C). The thickly pachyconic, almost involute specimen has weak steinkern constrictions, which extend with a concavo-convex course across flanks and venter. The smaller specimen MB.C.10152.1 (7 mm dm) has a similar conch, but with a slightly opened umbilicus (Fig. 12D). It possesses rather strong constrictions, which turn forward on the flank and form a shallow ventral sinus. The suture line of specimen
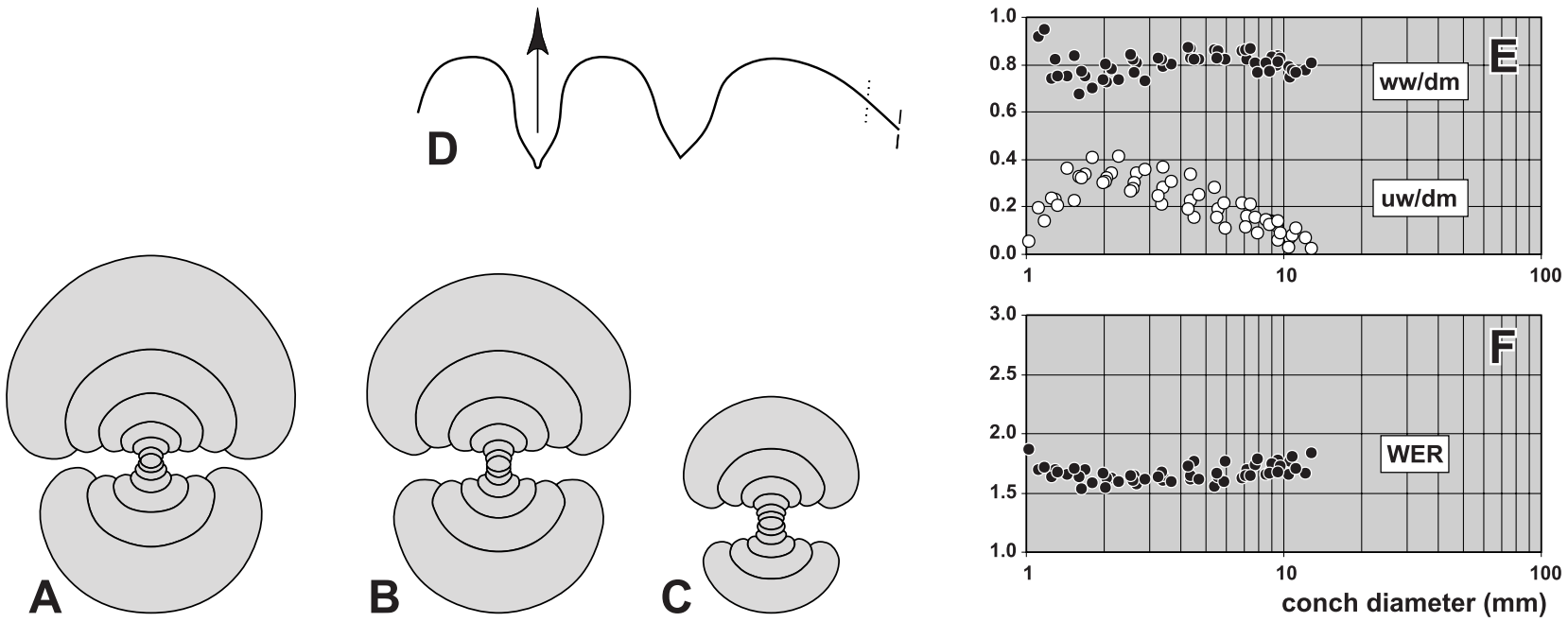

Fig. 13. Acutimitoceras depressum (Vöhringer, 1960) from bed 2 of the Aguelmous. A - Cross section, specimen MB.C.10190.1; ×3. B - Cross section, specimen MB.C.10152.3; ×3. C - Cross section, specimen MB.C.10214; $\times 3$. D - Suture line, specimen MB.C.10152.3, at $8.8 \mathrm{~mm}$ ww, $5.4 \mathrm{~mm}$ wh; $\times 5$. E - Ontogenetic development of the whorl width index (ww/dm) and umbilical width index (uw/dm). F - Ontogenetic development of the whorl expansion rate (WER). 
MB.C.10152.3 has a lanceolate external lobe with diverging flanks, a wide and broadly rounded ventrolateral saddle, and a V-shaped adventive lobe (Fig. 13D).

Discussion. The new material consists of rather small specimens, which fit well into the morphological spectrum of the Rhenish species. The species resembles A. kleinerae Korn, 1984, but can be distinguished by its narrower adventive lobe. A. intermedium (Schindewolf, 1923) has a more slender conch.

\section{Acutimitoceras sarahae n. sp}

Figs $12 \mathrm{E}-\mathrm{H}, 14$

Derivation of name. After Sarah Aboussalam who found the first Carboniferous specimen during our joined field trip to rediscover the Clariond locality.

Holotype. Specimen MB.C.10156.1; illustrated here in Fig. 12E.

Type locality and horizon. Bou Tlidat, Aguelmous (Ma'der, Anti-Atlas, Morocco); bed 2 (Early Tournaisian).

Ma te ri a l. Bou Tlidat (bed 2): 117 specimens, Tazoult (bed 2): 48 specimens, Tazoult (loose): 43 specimens, Rich El Mbidia (bed 2): 1 specimen, Tizi Ibaouâne (bed 2): 5 specimens.

Diagnosis. Species of Acutimitoceras with thickly discoidal to pachyconic conch ( $\mathrm{ww} / \mathrm{dm}=0.55-0.65$ at $12 \mathrm{~mm} \mathrm{dm}$ ). Inner whorls up to $5 \mathrm{~mm}$ diameter with very wide umbilicus (uw/dm $=0.40-0.50)$, umbilicus slightly open at $10 \mathrm{~mm}$ diameter and thereafter closing. Aperture moderate, whorl expansion rate $1.80-2.00$ in stages larger than $5 \mathrm{~mm}$ diameter. Steinkern with weak linear constrictions. Suture line with narrow, lanceolate external lobe and lanceolate adventive lobe with sinuous flanks.

Description. The general conch ontogeny closely resembles the preceding species, with a serpenticonic juvenile stage followed by a stage, in which the whorl height is enlarged and the umbilicus progressively closes. The whorl cross section is almost circular at $8-11 \mathrm{~mm}$ conch diameter but becomes laterally compressed at higher diameters (Fig. 14).

The holotype (MB.C.10156.1) is a medium-sized fully septate specimen $(15 \mathrm{~mm} \mathrm{dm})$, which has 12 chambers of equal length (Fig. 12E). It is thinly pachyconic $(\mathrm{ww} / \mathrm{dm}=0.61)$ and widest near the umbilicus with an almost closed, funnel-shaped umbilicus. The specimen has three irregularly spaced, weak constrictions. The suture line has a narrow, slightly pouched external lobe, a broadly rounded ventrolateral saddle, and a rather wide adventive lobe, in which the flanks are almost parallel in the upper part (Fig. 14F).

The smaller paratypes MB.C.10156.4 (6.5 mm $\mathrm{dm})$, MB.C.10156.3 (10 mm dm), and MB.C.10156.2 $(13 \mathrm{~mm} \mathrm{dm})$ show the transition from the juvenile to the adult stage, i.e., closing of the umbilicus, widening of the conch, and changing the course of the constrictions from concavo-convex to convex.

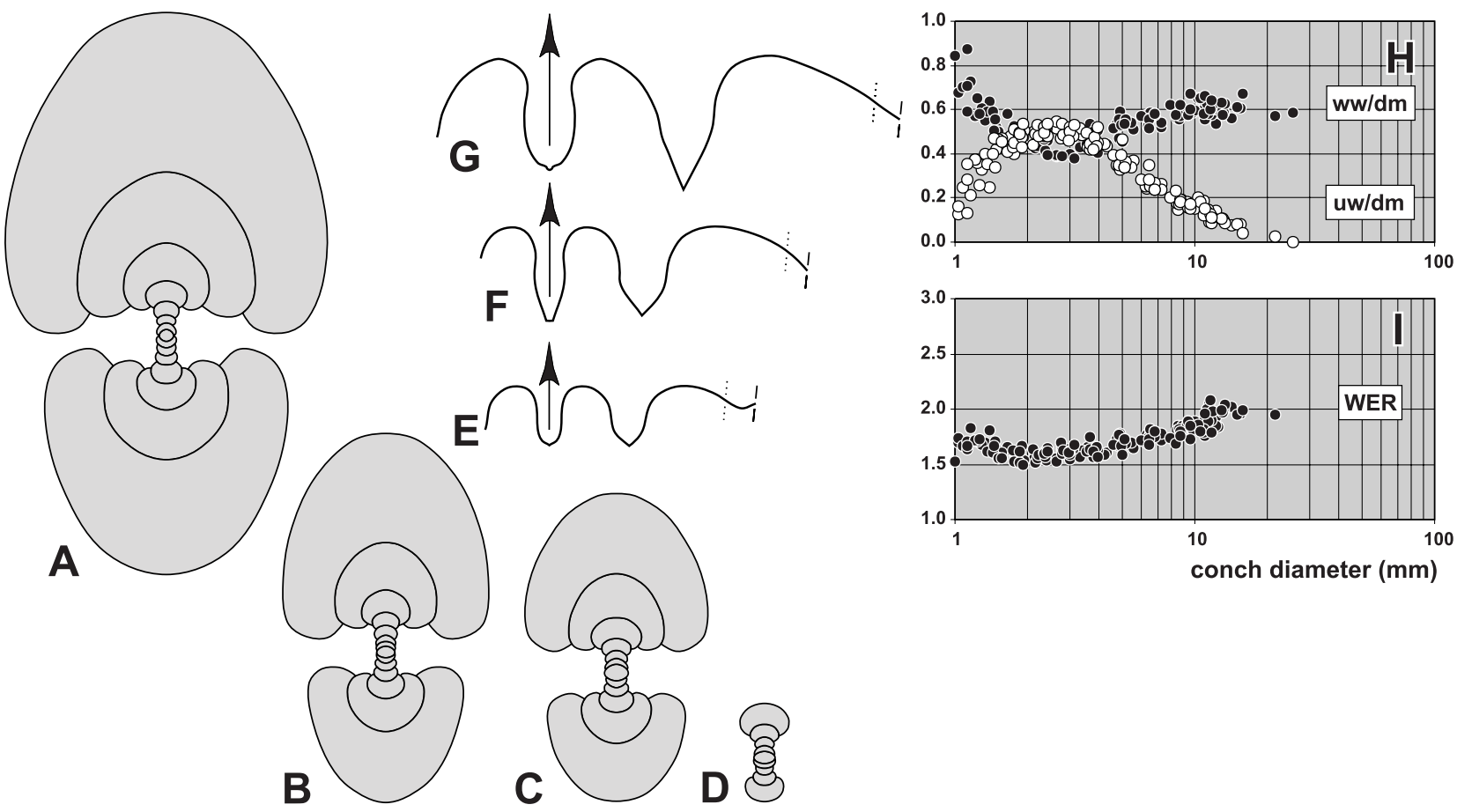

Fig. 14. Acutimitoceras sarahae n. sp. from bed 2 of the Aguelmous. A - Cross section, paratype MB.C.10207.1; $\times 3$. B - Cross section, paratype MB.C.10156.5; ×3. C - Cross section, paratype MB.C.10156.6; ×3. D - Cross section, paratype MB.C.10156.7; $\times 3$. E - Suture line (reversed), paratype MB.C.10156.8, at $4.3 \mathrm{~mm}$ ww, $3.1 \mathrm{~mm}$ wh; $\times 5$. F - Suture line, holotype MB.C.10156.1, at $14.4 \mathrm{~mm} \mathrm{dm}, 8.9 \mathrm{~mm}$ ww, $7.6 \mathrm{~mm}$ wh; $\times 3$. G - Suture line, paratype MB.C.10207.2, at $23.3 \mathrm{~mm} \mathrm{dm}$, $14.6 \mathrm{~mm}$ ww, $13.4 \mathrm{~mm}$ wh; $\times 2.5$. H - Ontogenetic development of the whorl width index $(\mathrm{ww} / \mathrm{dm})$ and umbilical width index (uw/dm). I - Ontogenetic development of the whorl expansion rate (WER). 
Discussion. A. sarahae differs from the co-occurring $A$. endoserpens n. sp. in having a wider conch, with a ww/wh ratio of 1.40 at $13 \mathrm{~mm}$ in $A$. sarahae and 1.00 in $A$. endoserpens. In A. hilarum Korn, 2002 similar conch ratios are seen, but the aperture is much lower in this species (WER $=1.70$ at $15 \mathrm{~mm} \mathrm{dm}$ ). Other species of Acutimitoceras, such as A. intermedium (Schindewolf, 1923) may possess similar adult conchs, but differ in the much less widely umbilicate juvenile stage.

\section{Acutimitoceras mfisense Bockwinkel \& Ebbighausen, 2006}

Figs $15 \mathrm{~A}-\mathrm{C}, 16$

* 2006 Acutimitoceras mfisense Bockwinkel \& Ebbighausen: 101, figs 16I, J, K, L, 18.

Material. Bou Tlidat (bed 2): 5 specimens, Tazoult (bed 2): 2 specimens, Tizi Ibaouâne (bed 2): 2 specimens.

Remarks. There is very close resemblance between the specimens from the type locality at Mfis and the material from Aguelmous, visible in the cross section (Fig. 16A), the suture line (Fig. 16B), and the ontogenetic trends of the conch geometry (Fig. 16C, D). An emendation of the original diagnosis is hence not required.

\section{Acutimitoceras endoserpens n. sp.}

Figs 15D-G, 17

Derivation of name. Named after the serpenticonic internal whorls.
Holotype. Specimen MB.C.10153.1; illustrated here in Fig. 15E.

Type locality and horizon. Bou Tlidat, Aguelmous (Ma'der, Anti-Atlas, Morocco); bed 2 (Early Tournaisian).

Material. Bou Tlidat (bed 2): 99 specimens, Bou Tlidat (bed 12): 1 specimen, Tazoult (bed 2): 11 specimens, Tazoult (loose): 20 specimens, Rich El Mbidia (bed 2): 2 specimens, Tizi Ibaouâne (bed 2): 7 specimens, Tizi Malilane (bed 2): 2 specimens.

Diagnosis. Species of Acutimitoceras with thickly discoidal conch $(w w / d m=0.45-0.55$ at $12 \mathrm{~mm} \mathrm{dm})$. Inner whorls up to $6 \mathrm{~mm}$ diameter with very wide umbilicus $(\mathrm{uw} / \mathrm{dm}=$ $0.40-0.55$ ), umbilicus slightly open at $10 \mathrm{~mm}$ diameter and thereafter rapidly closing. Aperture moderate, whorl expansion rate 1.80-2.00 in stages larger than $5 \mathrm{~mm}$ diameter. Steinkern with wellpreserved linear constrictions. Suture line with very narrow, lanceolate external lobe and very narrow, V-shaped adventive lobe.

Description. A number of cross sections were prepared (Fig. 17A-F); these permitted the detailed study of ontogenetic changes of the species. Variability within the material is limited but as can be seen in the growth curves, there are significant ontogenetic changes (Fig. 17I, J). There is a serpenticonic juvenile stage up to about $6 \mathrm{~mm}$ conch diameter, and thereafter, rapid overlapping of whorls takes place with the result of an involute, discoidal conch with laterally compressed whorl cross section. This development is paralleled by a continuous increase of the apertural height; the whorl expansion rate ranges between 1.50 and 1.60 at $6 \mathrm{~mm} \mathrm{dm}$ and then increases to $1.75-2.00$ at $15 \mathrm{~mm} \mathrm{dm}$.

Holotype MB.C.10153.1 is a well preserved, fully septate preadult specimen with a nearly $13 \mathrm{~mm}$
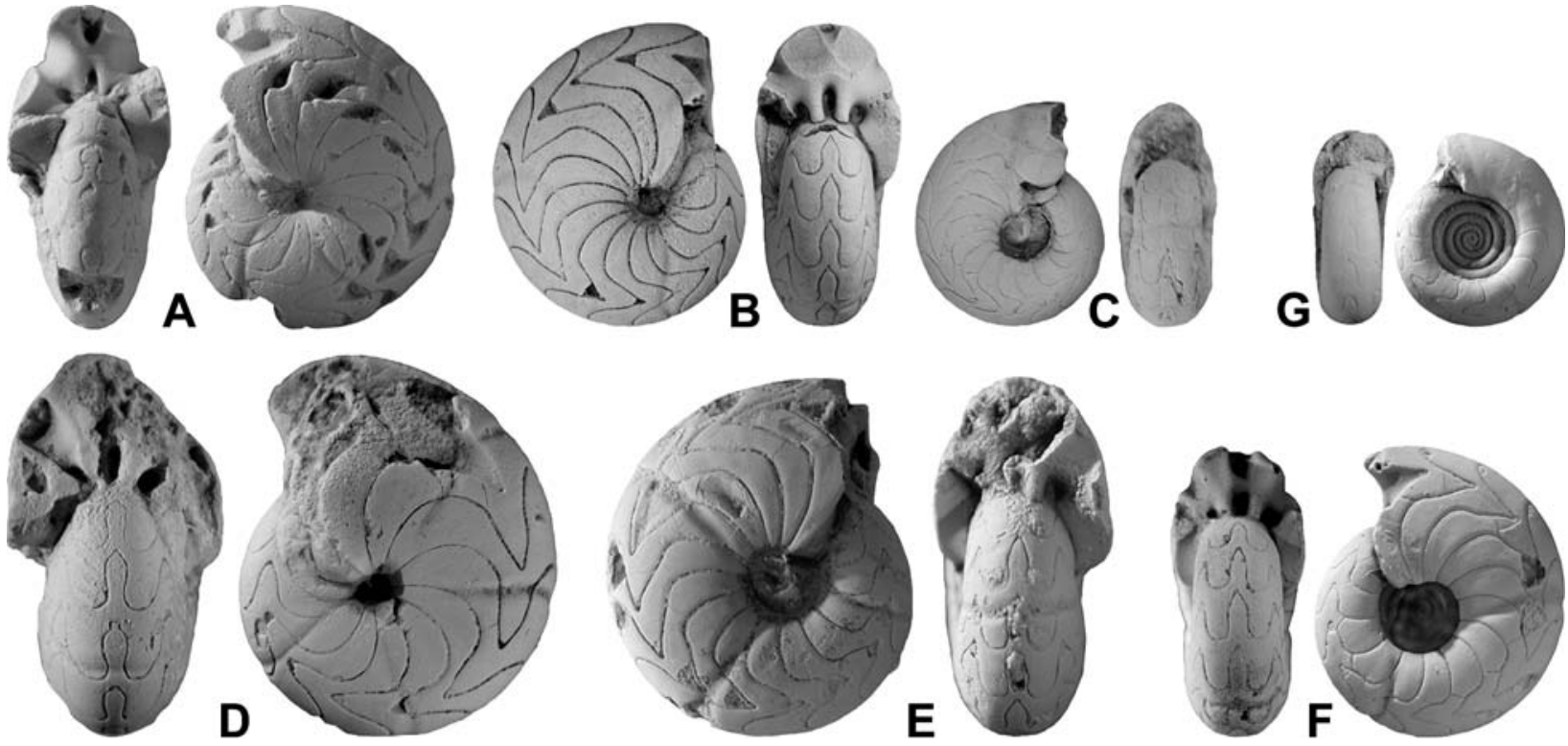

Fig. 15. Acutimitoceras from Fezzou, all $\times$ 3. A - Acutimitoceras mfisense Bockwinkel \& Ebbighausen, 2006, specimen MB.C.10157.2 from Bou Tlidat, bed 2, dorsal and lateral views. B - Acutimitoceras mfisense Bockwinkel \& Ebbighausen, 2006, specimen MB.C.10217 from Tizi Ibaouâne, bed 2, lateral and dorsal views. C - Acutimitoceras mfisense Bockwinkel \& Ebbighausen, 2006, specimen MB.C.10195.1 from Tazoult, bed 2, lateral and dorsal views. D - Acutimitoceras endoserpens n. sp. paratype MB.C.10215.1 from Bou Tlidat, bed 2, dorsal and lateral views. E - Acutimitoceras endoserpens n. sp. holotype MB.C.10153.1 from Bou Tlidat, bed 2, lateral and dorsal views. F - Acutimitoceras endoserpens n. sp. paratype MB.C.10153.2 from Bou Tlidat, bed 2, dorsal and lateral views. G - Acutimitoceras endoserpens n. sp. paratype MB.C.10191.1 from Tazoult, dorsal and lateral views. 


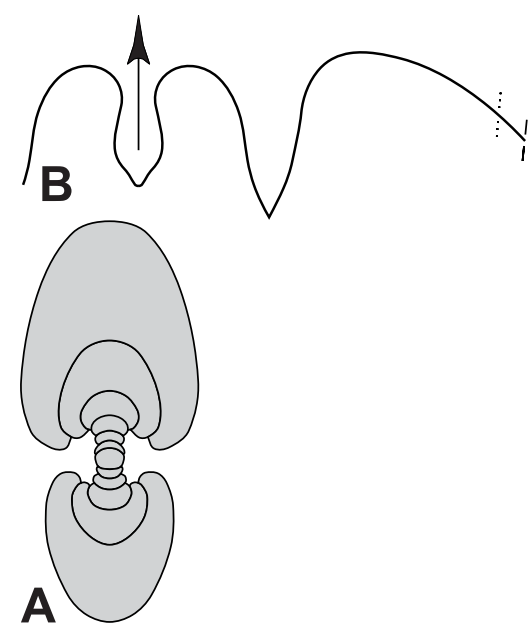

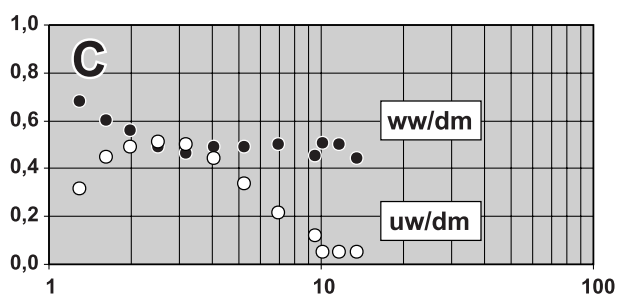

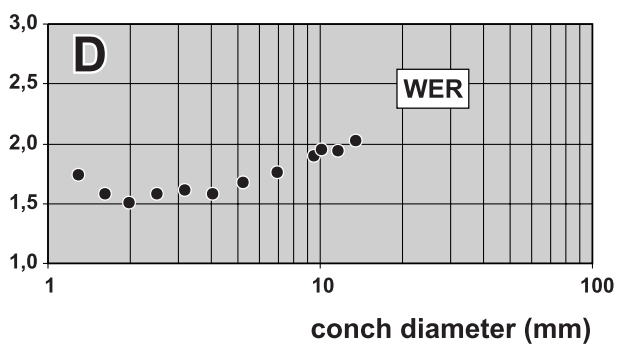

Fig. 16. Acutimitoceras mfisense Bockwinkel \& Ebbighausen, 2006 from bed 2 of the Aguelmous. A - Cross section, specimen MB.C.10157.1; $\times 3$. B - Suture line, specimen MB.C.10157.2, at $10.6 \mathrm{~mm} \mathrm{dm}, 5.1 \mathrm{~mm}$ ww, $5,7 \mathrm{~mm}$ wh; $\times 6$. C - Ontogenetic development of the whorl width index (ww/dm) and umbilical width index (uw/dm). D - Ontogenetic development of the whorl expansion rate (WER). conch diameter (Fig. 15E). It has 15 chambers with almost equal distances on the last preserved whorl. Conch proportions are: $\mathrm{ww} / \mathrm{dm}=0.48, \mathrm{uw} / \mathrm{dm}=$ 0.15 , but the specimen shows the almost complete closure of the umbilicus on the following whorl, of which the umbilical wall is impressed in the matrix that is preserved in the umbilicus. The specimen has four constrictions at variable distances; these constrictions extend linearly over the flanks and turn back to create a very shallow ventral sinus. The suture line has a narrow and deep, lanceolate external lobe, an asymmetric, ventrally inclined ventrolateral saddle, and a slightly asymmetric, V-shaped adventive lobe (Fig. 17H).

The umbilicus is almost completely closed in specimens above $13 \mathrm{~mm} \mathrm{dm}$, such as MB.C.10215.1 (Fig. 15D). Smaller specimens, e.g. MB.C.10153.2 (10 mm dm) and MB.C.10191.1 (7 mm dm) display a very different morphology with open umbilicus and an almost circular whorl cross section. They show rather deep, protracted steinkern constrictions which have a well-developed ventral sinus (Fig. 15F, G).

Discussion. The new form belongs to the group of open-umbilicate species within Acutimitoceras. A. hilarum Korn, 2002 is similar in this respect with a pachyconic conch (ww/dm $=0.65$ at $15 \mathrm{~mm} \mathrm{dm})$ and a lower aperture $(\mathrm{WER}=1.70)$. A. antecedens (Vöhringer, 1960) appears to be identical in conch shape and suture line, but differs in the absence of steinkern constrictions. A. mfisense Bockwinkel \& Ebbighausen, 2006 also differs in the shorter external lobe. A. sarahae n. sp. has a wider conch (ww/ $\mathrm{dm}=0.55-0.65)$ and a wider adventive lobe. Nicimitoceras heterolobatum (Vöhringer, 1960) has a shorter adventive lobe, an asymmetric adventive lobe, and lacks constrictions.

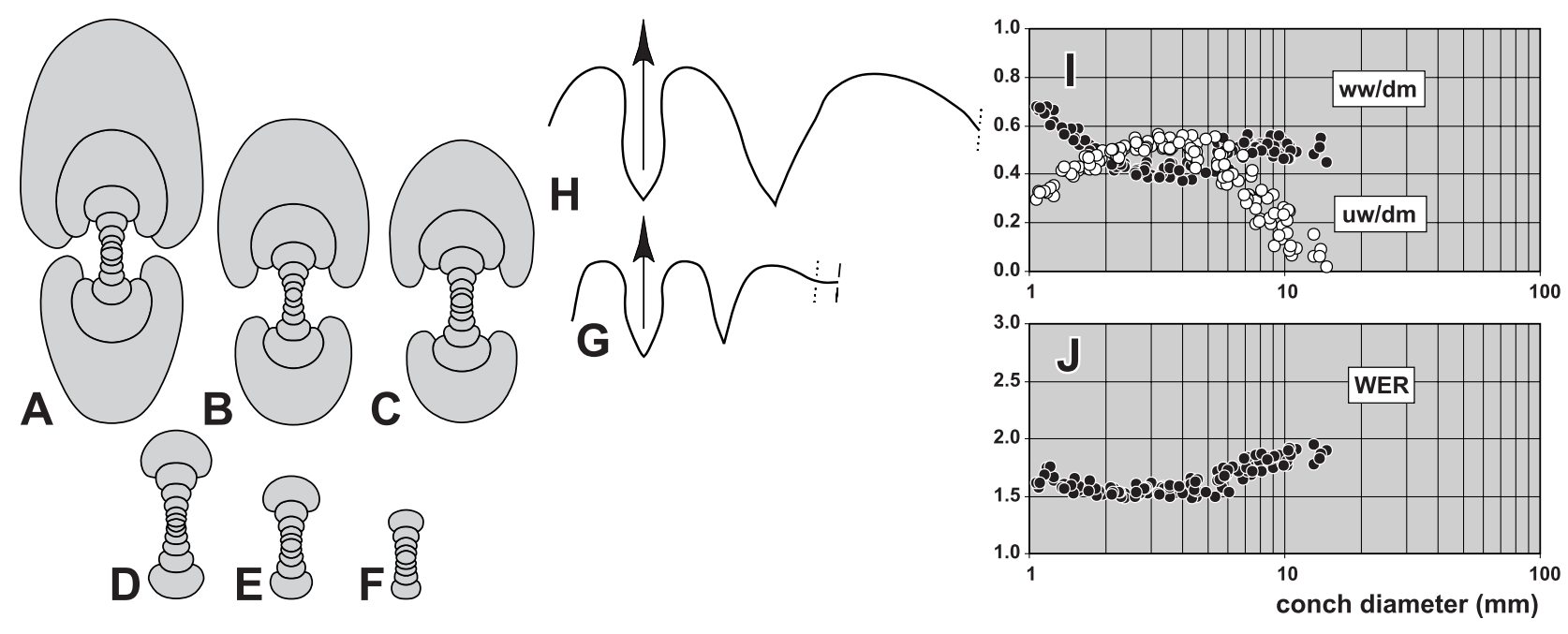

Fig. 17. Acutimitoceras endoserpens n. sp. from bed 2 of the Aguelmous. A - Cross section, paratype MB.C.10153.3; $\times 3$. B - Cross section, paratype MB.C.10191.2; $\times 3$. C. Cross section, paratype MB.C.10153.4; $\times 3$. D - Cross section, paratype MB.C.10153.5; $\times 3$. E - Cross section, paratype MB.C.10191.3; $\times 3$. F - Cross section, paratype MB.C.10153.6; $\times 3$. G - Suture line, paratype MB.C.10173.1, at $6.4 \mathrm{~mm} \mathrm{dm}, 2.9 \mathrm{~mm}$ ww, $1.7 \mathrm{~mm}$ wh; $\times 5$. H - Suture line (reversed), holotype MB.C.10153.1, at $12.5 \mathrm{~mm} \mathrm{dm}, 5.9 \mathrm{~mm}$ ww, $6.4 \mathrm{~mm}$ wh; $\times 5$. I - Ontogenetic development of the whorl width index (ww/dm) and umbilical width index (uw/dm). $\mathbf{J}$ - Ontogenetic development of the whorl expansion rate (WER). 
Acutimitoceras algeriense Ebbighausen, Bockwinkel, Korn \& Weyer, 2004

Figs $18 \mathrm{~A}-\mathrm{C}, 19$

* 2004 Acutimitoceras algeriense Ebbighausen, Bockwinkel, Korn \& Weyer: 136, fig. 3A-F.

Material. Bou Tlidat (bed 2): 1 specimen, Rich El Mbidia (bed 16): 3 specimens, Tizi Ibaouâne (bed 12): 17 specimens, Tizi Ibaouâne (bed 16): 5 specimens.
Remarks. The smaller individuals from bed 16 closely resemble Algerian material, and there is no doubt that they belong to the same species. They possess the discoidal conch with the punctiform umbilicus, the short evolute juvenile stage, and the biconvex constrictions of the steinkern. Larger specimens such as MB.C.10228.5 (30 mm $\mathrm{dm})$, MB.C.10228.2 (64 mm dm; Fig. 19A), and MB.C.10228.1 (86 mm dm; Fig. 18A) are preserved
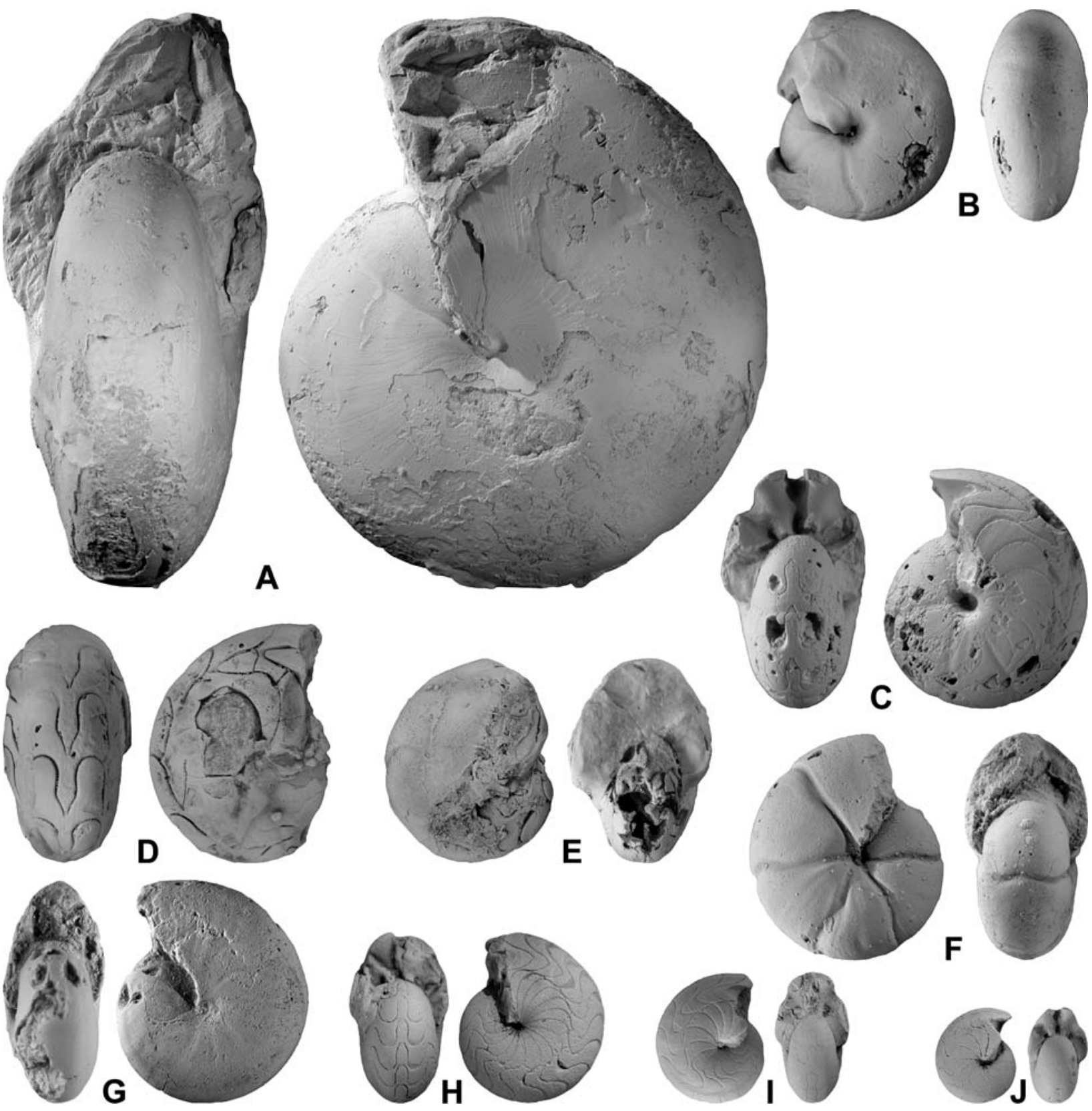

Fig. 18. Acutimitoceras and Costimitoceras from Fezzou. A - Acutimitoceras algeriense Ebbighausen et al. 2004, specimen MB.C.10228.1 from Tizi Ibaouâne, bed 16, dorsal and lateral views, $\times 1$. B - Acutimitoceras algeriense Ebbighausen et al. 2004, specimen MB.C.10222.1 from Tizi Ibaouâne, bed 12, lateral and dorsal views, $\times 1.5$. C - Acutimitoceras algeriense Ebbighausen et al. 2004, specimen MB.C.10151 from Bou Tlidat, bed 2, dorsal and lateral views, $\times 2.5$. D - Acutimitoceras sp. A, specimen MB.C.10223.1 from Tizi Ibaouâne, bed 12, dorsal and lateral views, $\times 1$. E - Acutimitoceras sp. A, specimen MB.C.10223.2 from Tizi Ibaouâne, bed 12, dorsal and lateral views, $\times 1$. F - Acutimitoceras pentaconstrictum $\mathrm{n}$. sp., holotype from Tizi Ibaouâne, bed 2, lateral and dorsal views, $\times 3$. G - Costimitoceras aitouamar n. sp., holotype MB.C.10159.1 from Bou Tlidat, bed 2, dorsal and lateral views, $\times 3$. H - Costimitoceras aitouamar n. sp., paratype MB.C.10159.2 from Bou Tlidat, bed 2, dorsal and lateral views, $\times 3$. I - Costimitoceras aitouamar n. sp., paratype MB.C.10210.1 from Tazoult, bed unknown, lateral and dorsal views, $\times 3$. J - Costimitoceras aitouamar n. sp., paratype MB.C.10159.5 from Bou Tlidat, bed 2 lateral and dorsal views, $\times 3$. 

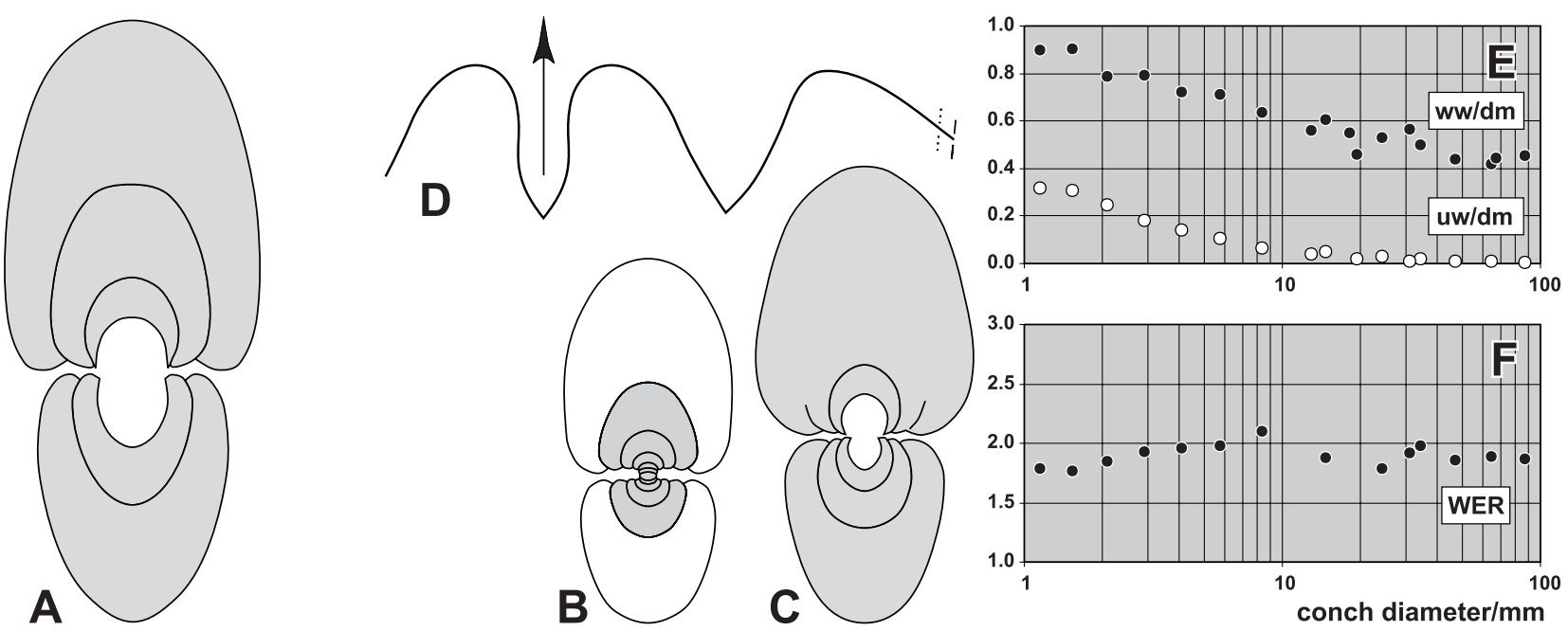

Fig. 19. Acutimitoceras algeriense Ebbighausen et al., 2004 from bed 12 and 16 of the Aguelmous. A - Cross section, specimen MB.C.10228.2 from bed 16, $\times 1$. B - Cross section, specimen MB.C.10228.3 from bed 16, $\times 2$. C - Cross section, specimen MB.C.10222.2 from bed 12, ×2. D - Suture line, specimen MB.C.10228.4 from bed 16, at $10.5 \mathrm{~mm} \mathrm{dm}, 6.2 \mathrm{~mm} \mathrm{ww}, 5.9 \mathrm{~mm}$ wh; $\times 8$. E - Ontogenetic development of the whorl width index (ww/dm) and umbilical width index (uw/dm). F - Ontogenetic development of the whorl expansion rate (WER).

in sideritic nodules; they have a similar conch morphology but possess convex growth lines and lack constrictions.

\section{Acutimitoceras sp. A}

Figs 18D, E, 20

Material. Bou Tlidat (bed 12): 1 specimen, Tizi Ibaouâne (bed 12): 18 specimens.

Remarks. It is not certain that every specimen belongs to the same species, but they all show a thickly discoidal conch above $10 \mathrm{~mm} \mathrm{dm}$, a closed umbilicus, and a steinkern with concavo-convex constrictions. They differ each other in their conch width; some specimens including MB.C.10223.1 resemble A. subbilobatum $(\mathrm{ww} / \mathrm{dm}=0.50)$, whereas others, such as MB.C.10223.2 are closer to A. intermedium $(\mathrm{ww} / \mathrm{dm}=0.65)$. The cross sections MB.C.10223.3 and MB.C.10223.4 (Fig. 20A, B) show tegoid conchs with a closed umbilicus, an oblique umbilical wall, and rather strongly converging flanks.

\section{Acutimitoceras sp. B}

\section{Fig. 21}

Material. Tazoult (loose): 2 specimens.

Remarks. Two specimens preserved as siderite have been sectioned, and, based on conch differ-
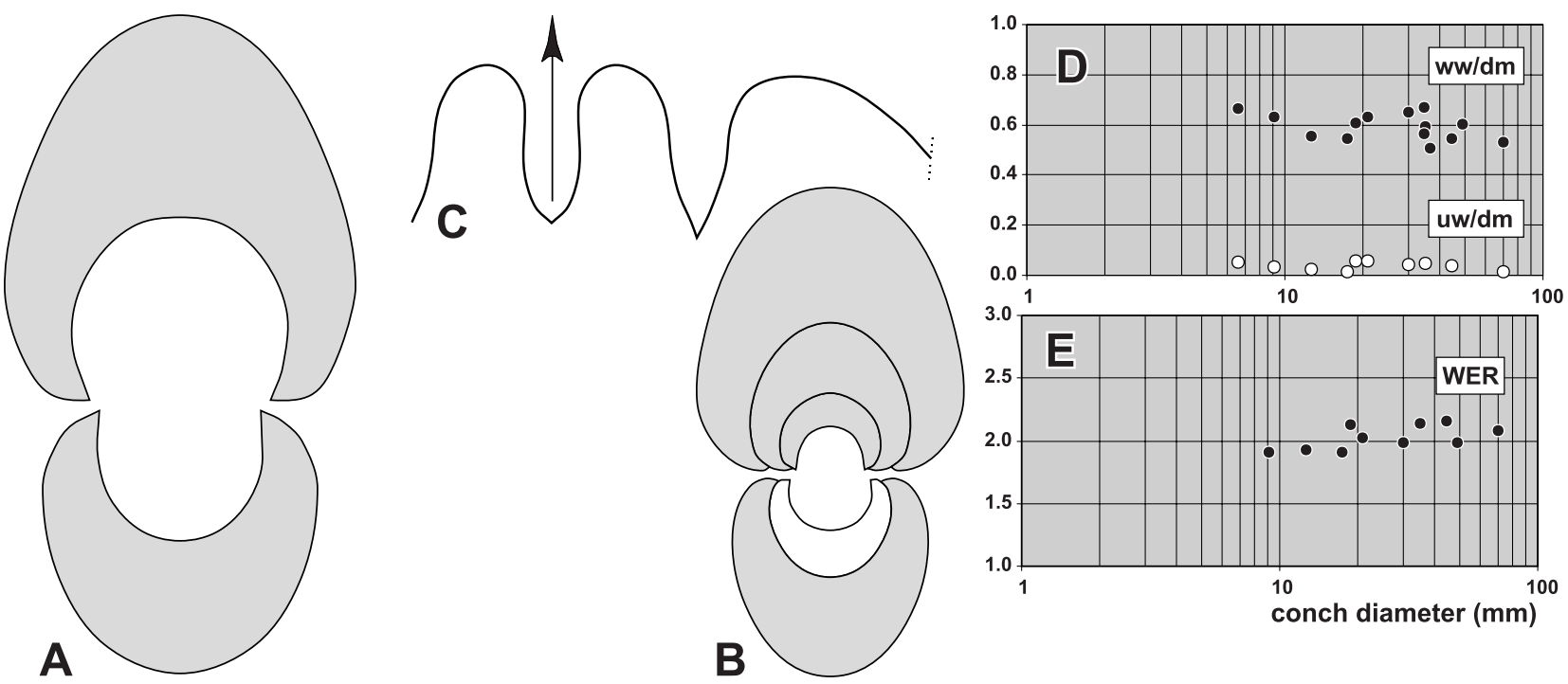

Fig. 20. Acutimitoceras sp. A from bed 12 of the Aguelmous. A - Cross section, specimen MB.C.10223.3; $\times 1$. B - Cross section, specimen MB.C.10223.4; $\times 3$. C - Suture line, specimen MB.C.10223.5, at $18.9 \mathrm{~mm} w \mathrm{wh} \times 2$. D - Ontogenetic development of the whorl width index (ww/dm) and umbilical width index (uw/dm). E - Ontogenetic development of the whorl expansion rate (WER). 
<smiles>CCC1=CCCCCCCCCCC1C</smiles>
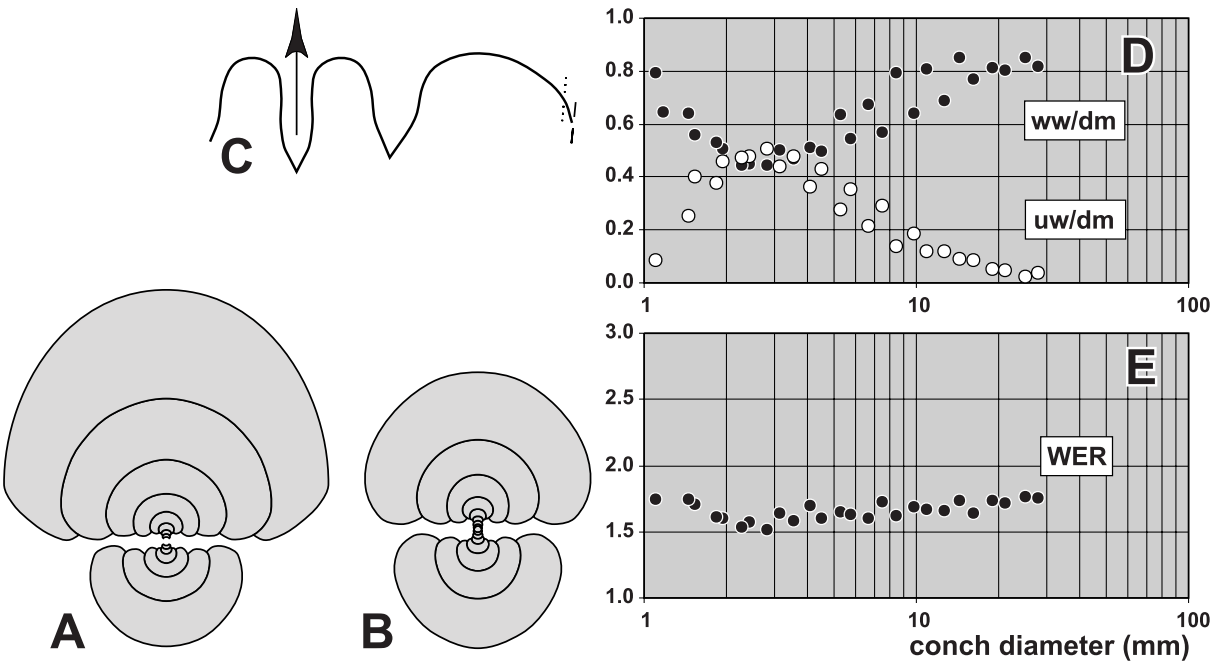

Fig. 21. Acutimitoceras sp. B from bed 2 of the Aguelmous. A - Cross section, specimen MB.C.10209.1; $\times 1$. B - Cross section, specimen MB.C.10209.2; ×1. C - Suture line, specimen MB.C.10209.1, at $33.0 \mathrm{~mm}$ ww, $19.5 \mathrm{~mm}$ wh; $\times 1$. D - Ontogenetic development of the whorl width index (ww/dm) and umbilical width index (uw/dm). E - Ontogenetic development of the whorl expansion rate (WER). ences, it is not clear if they belong to the same species (Fig. 21A, B). Both have very evolute inner whorls with a maximum $\mathrm{uw} / \mathrm{dm}$ ratio of $0.40-0.50$ at $2-4 \mathrm{~mm}$ conch diameter. The umbilicus is closed at $20 \mathrm{~mm} \mathrm{dm}$. The ww/dm ratio is lowest when the umbilicus is widest, followed by an increase of the ww ratio. The conchs are thickly pachyconic (ww/ $\mathrm{dm}=0.80)$ at $20 \mathrm{~mm} \mathrm{dm}$.

The suture line of specimen MB.C.10209.1 possesses a deep and narrow lanceolate external lobe, which is slightly pouched. A broadly rounded ventrolateral saddle and a V-shaped adventive lobe is present on the flank (Fig. 21C).

\section{Acutimitoceras posterum Bockwinkel \& Ebbighausen, 2006}

Fig. 22

* 2006 Acutimitoceras posterum Bockwinkel \& Ebbighausen: 100 , figs $16 \mathrm{E}-\mathrm{H}, 17 \mathrm{~A}-\mathrm{F}$.

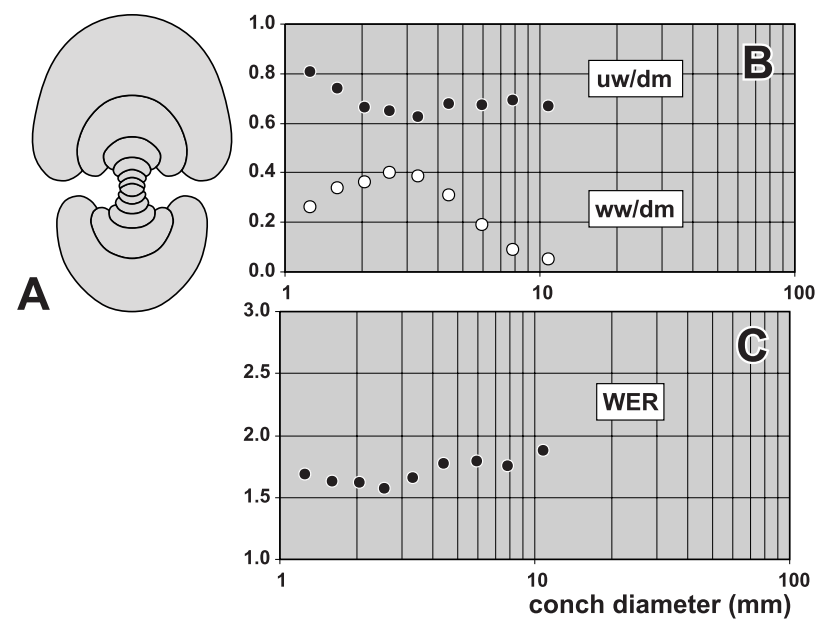

Fig. 22. Acutimitoceras posterum Bockwinkel \& Ebbighausen, 2006 from bed 16 of the Aguelmous. A - Cross section, specimen MB.C.10229; $\times 3$. B - Ontogenetic development of the whorl width index (ww/dm) and umbilical width index (uw/ $\mathrm{dm})$. C - Ontogenetic development of the whorl expansion rate (WER).
Material. Tizi Ibaouâne (bed 16): 1 specimen.

Remarks. The single specimen MB.C.10229 (Fig. 22) confirms the description of the original material from Mfis.

\section{Acutimitoceras pentaconstrictum n. sp. Figs 18F, 23}

Derivation of name. Named after the five steinkern constrictions.

Hol o t y p e. Specimen MB.C.10218; illustrated here in Fig. 18F. Type locality and horizon. Tizi Ibaouâne, Aguelmous (Ma'der, Anti-Atlas, Morocco); bed 2 (Early Tournaisian).

Material. Holotype.

Diagnosis. Species of Acutimitoceras with thickly discoidal conch $(w w / d m=0.50-0.55$ at $12 \mathrm{~mm} \mathrm{dm})$, umbilicus closed. Aperture moderate, whorl expansion rate 1.75. Steinkern with strong biconvex constrictions. Suture line with V-shaped external lobe and tongue-shaped, rounded adventive lobe.

Description. The holotype has a diameter of almost $12 \mathrm{~mm}$, and the last whorl largely represents the body chamber (Fig. 18F). It is discoidal (ww/dm $=0.52$ ) with a punctiform umbilicus. Flanks and venter are continuously rounded, and the umbilical wall is oblique. The steinkern has strong constrictions, which are almost exactly arranged in distances of $60^{\circ}$. Their course is biconvex with a very low dorsolateral and a more pronounced ventrolateral projection. The ventral sinus is shallow and slightly chevron-shaped. The suture lines shows juvenile aspects, e.g. the external lobe is V-shaped and the adventive lobe is rounded (Fig. 23).

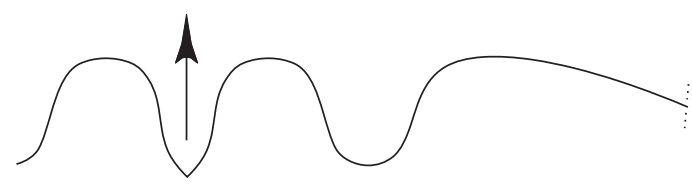

Fig. 23. Acutimitoceras pentaconstrictum n. sp. from bed 2 of the Aguelmous. Suture line (reversed), holotype MB.C.10218, at $4.1 \mathrm{~mm}$ ww, $3.7 \mathrm{~mm}$ wh; $\times 10$. 
Discussion. A. pentaconstrictum has a somewhat isolated position within the genus. Strong steinkern constrictions are present in some other species, such as $A$. prorsum (Schmidt, 1925) and A. stockumense Korn, 1984, but these species possess an open umbilicus at the stage when the new species is already completely involute. The most similar species is obviously "Mimimitoceras crestaverde Korn, 1992" from the Gattendorfia Stufe of the Carnic Alps (Korn 1992b), of which only one small specimen is known.

\section{Costimitoceras Vöhringer, 1960}

Type species. Costimitoceras ornatum Vöhringer, 1960

Composition of the genus.

Costimitoceras ornatum Vöhringer, 1960; Gattendorfia Stufe, Rhenish Mountains.

Costimitoceras epichare (Ruan, 1981); Gattendorfia Fauna, Guizhou.

Costimitoceras aitouamar n. sp.; Gattendorfia-Eocanites assemblage; Anti-Atlas.

Genus definition. Acutimitoceratinae with biconvex growth lines, which form a pronounced ventrolateral salient. Spiral lines and/or ventrolateral grooves may be present.

D is cus s i on. Only two species are thus far included in the genus Costimitoceras, and these may even be synonyms. With the new form described below, another species that most likely belongs to the genus is introduced. Unfortunately, there is no shell preserved in this new material and thus the generic assignment is not completely certain. The strikingly biconvex growth lines, the periodically strengthened growth lines, and the weak spirals impressed on the steinkern in the new species however, make such an assignment most likely.

\section{Costimitoceras aitouamar n. sp.}

Figs $18 \mathrm{G}-\mathrm{J}, 24$

Derivation of name. After the village and family of Ait Ouamar, owing to their hospitality.

Holotype. Specimen MB.C.10159.1; illustrated here in Fig. 18G.

Type locality and horizon. Bou Tlidat, Aguelmous (Ma'der, Anti-Atlas, Morocco); bed 2 (Early Tournaisian).

Material. Bou Tlidat (bed 2): 34 specimens, Bou Tlidat (bed 12): 1 specimen, Tazoult (bed 2): 15 specimens, Tazoult (loose): 11 specimens.

Diagnosis. Species of Costimitoceras with thickly discoidal conch $(w w / d m=0.55$ at $10 \mathrm{~mm} \mathrm{dm})$. Inner whorls up to $2 \mathrm{~mm}$ diameter with moderate umbilicus $(\mathrm{uw} / \mathrm{dm}=0.20$ ). Aperture low in the juvenile stage and becoming higher during ontogeny; whorl expansion rate higher than 2.00 at $10 \mathrm{~mm}$ diameter. Steinkern without constrictions, shallow ventrolateral groove. Suture line with narrow, lanceolate external lobe and V-shaped, subacute adventive lobe.

Description. The bivariate plots show that within the sectioned specimens, there is rather little variability in conch width and umbilical width ratios, but the whorl expansion rate has a wider range (Fig. $24 \mathrm{H}$, I). The cross section of specimen MB.C.10197.1 shows a short, widely umbilicate juvenile stage, and already the third whorl embraces the preceding to a large degree (Fig. 24A). The umbilicus is closed by the fourth whorl at about $2 \mathrm{~mm}$ conch diameter. The conch becomes continuously thinner during ontogeny, and the umbilicus remains closed.

Holotype MB.C.10159.1 is, at a diameter of $11.5 \mathrm{~mm}$, the largest of the specimens (Fig. 18G). Its last whorl belongs almost completely to the body chamber that shows some impressions of the shell surface. The conch is slightly distorted, being lenticular with an almost closed umbilicus. A shallow ventrolateral groove is fairly well visible; it

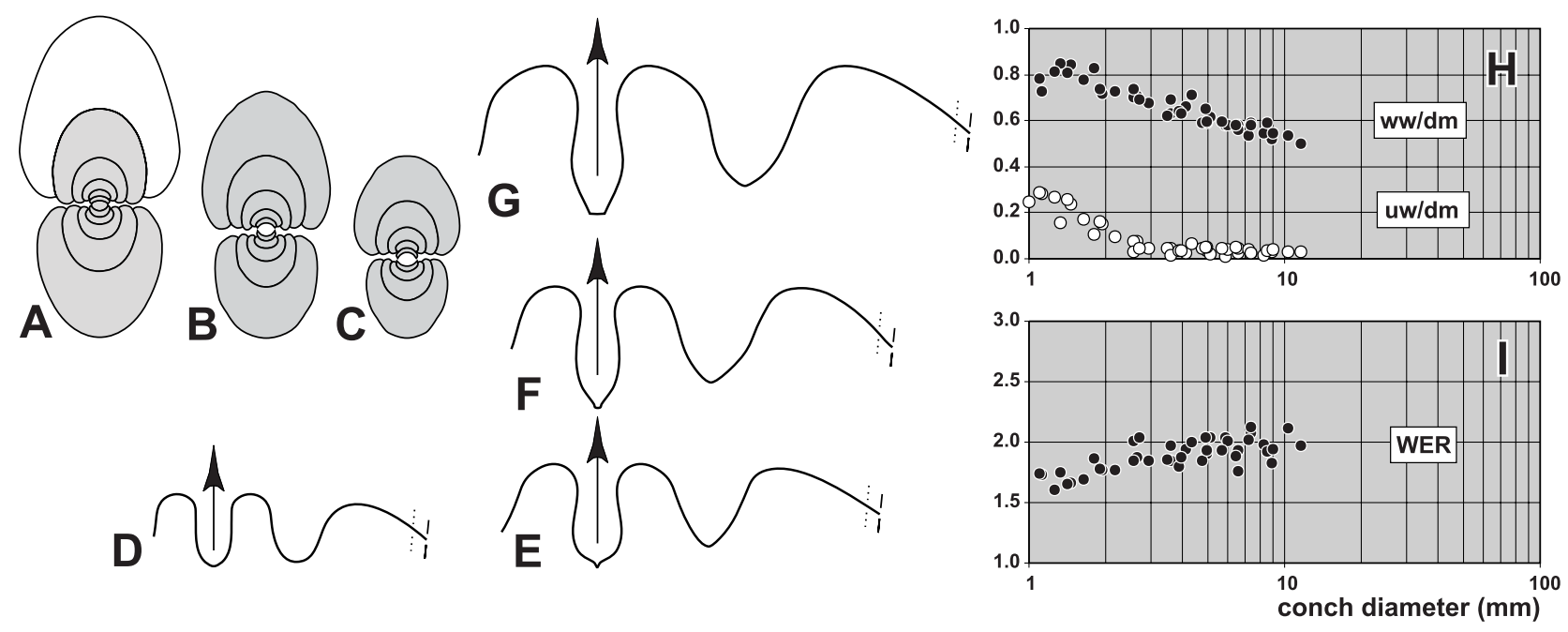

Fig. 24. Costimitoceras aitouamar n. sp. from Bed 2 of the Aguelmous. A - Cross section, paratype MB.C.10197.1; $\times 3$. B - Cross section, paratype MB.C.10159.3; $\times 3$. C - Cross section, paratype MB.C.10197.2; ×3. D - Suture line, paratype MB.C.10159.4, at $2.5 \mathrm{~mm} \mathrm{dm}, 1.7 \mathrm{~mm}$ ww, $1.4 \mathrm{~mm}$ wh; $\times 14 . \mathbf{E}-$ Suture line (reversed), paratype MB.C.10159.5, at $4.7 \mathrm{~mm} \mathrm{dm}, 3.0 \mathrm{~mm}$ ww, $2.5 \mathrm{~mm}$ wh; $\times 10$. F - Suture line, paratype MB.C.10159.6, at $7.3 \mathrm{~mm} \mathrm{dm}, 3.9 \mathrm{~mm}$ ww, $4.1 \mathrm{~mm}$ wh; $\times 7$. G - Suture line, paratype MB.C.10159.7, at $9.2 \mathrm{~mm} \mathrm{dm}, 5.0 \mathrm{~mm}$ ww, $5.3 \mathrm{~mm}$ wh; $\times 7$. H - Ontogenetic development of the whorl width index $(\mathrm{ww} / \mathrm{dm})$ and umbilical width index (uw/dm). I - Ontogenetic development of the whorl expansion rate (WER). 
separates the flanks from the narrow venter. The body chamber shows impressions of periodically strengthened growth lines, which extend with biconvex course on flanks and venter, forming a prominent ventrolateral projection and a rather deep ventral sinus. At the terminal end, impressions of a spiral ornament are visible in the ventrolateral region.

Smaller specimens such as paratype MB.C.10210.1 show a very similar conch morphology and a similar ornament impression, but without traces of spiral lines (Fig. 18I). The umbilicus is punctiform in these specimens.

The ontogeny of the suture line shows a narrowing of the external lobe, which is U-shaped in the early juvenile stage and deep and lanceolate in later growth stages (Fig. 24D-G). The ventrolateral saddle is strikingly asymmetric and highest on the ventral side, and the adventive lobe is subacute and V-shaped.

Discussion. The new species has a conch geometry that closely resembles $C$. ornatum Vöhringer, 1960 , but with a narrower umbilicate juvenile stage. Shell ornament is not preserved in the new species, and hence it is not clear if the species has a dense spiral ornament such as the type species of the genus. However, both species are very similar In the strength of the biconvex growth lines.

\section{Hasselbachia Korn \& Weyer, 2003}

Type species. Imitoceras multisulcatum Vöhringer, 1960.

\section{Hasselbachia gourara Ebbighausen, Bockwinkel, Korn \& Weyer, 2004 \\ Figs 25A, B, 26}
* 2004 Hasselbachia gourara Ebbighausen, Bockwinkel, Korn \& Weyer: 140 , fig. 8 A-F

Material. Rich El Mbidia (bed 16): 1 specimen, Tizi Ibaouâne (bed 16): 3 specimens.

Diagnosis. Species of Hasselbachia with discoidal conch $($ ww/dm $=0.50-0.55$ at $10 \mathrm{~mm} \mathrm{dm})$. Inner whorls up to $5 \mathrm{~mm}$ diameter widely umbilicate (uw/dm 0.40), umbilicus narrower in later stages (uw $/ \mathrm{dm}=0.30$ at $18 \mathrm{~mm} \mathrm{dm}$ ). Aperture very low, whorl expansion rate 1.50 . Steinkern without or with weak constrictions that become more pronounced in the adult stage. Suture line with wide, parallel-sided external lobe and parallel-sided adventive lobe.

Description. The new material is much better preserved than the Algerian type material and allows an upgrade of the Diagnosis. Specimen MB.C.10234.1 with $18 \mathrm{~mm}$ conch diameter is the largest of the specimens (Fig. 25A); it has a body chamber with some strongly weathered shell. The conch is lenticular $(\mathrm{ww} / \mathrm{dm}=0.47)$ with an open umbilicus $(\mathrm{uw} / \mathrm{dm}=0.30)$. Flanks and venter are rounded, and the umbilical edge is subangular. The last volution has three irregularly spaced steinkern constrictions, which turn backward from the umbilicus and then extend almost linearly across flanks and venter. Traces of radial ornament are visible on the steinkern, possibly caused by rhythmically strengthened growth lines. These lines turn more strongly backward than the constrictions and form a deep ventral sinus.

Smaller specimens such as MB.C.10233.8 (11 mm $\mathrm{dm})$ and MB.C.10234.2 (9 mm dm) show a similar
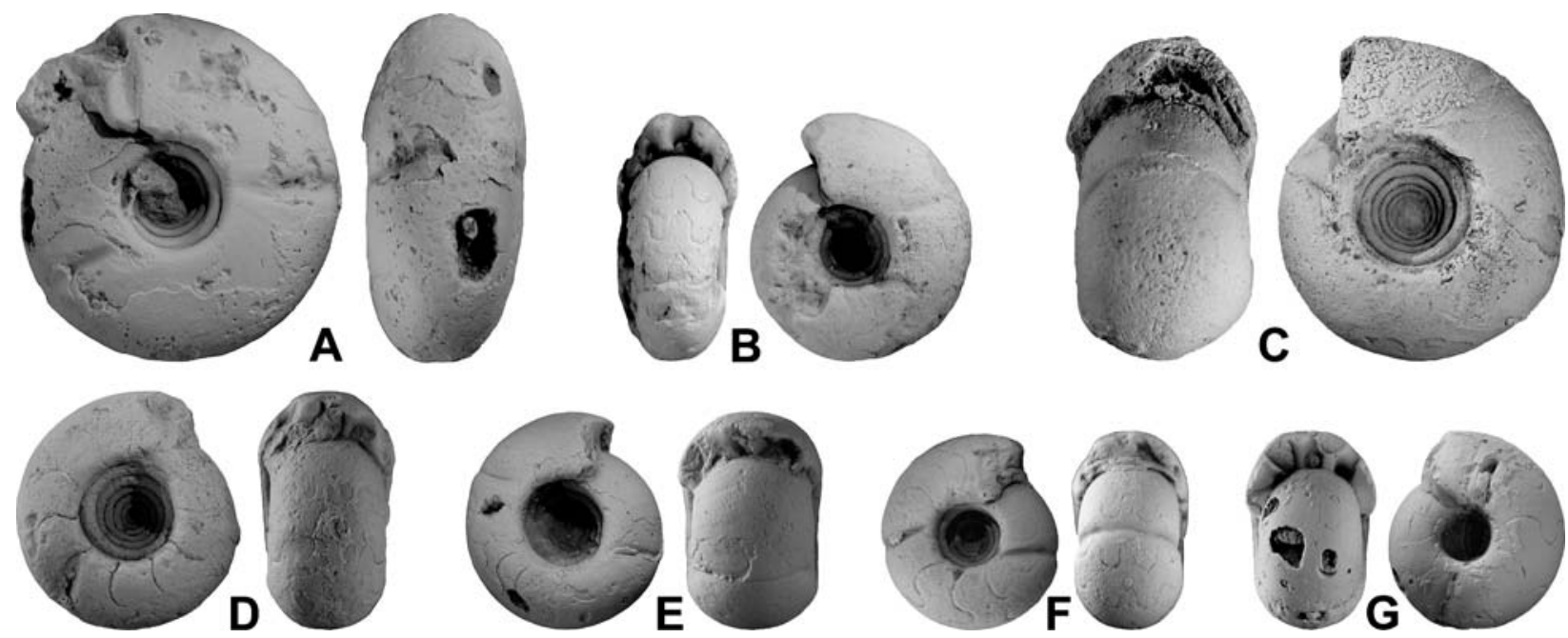

Fig. 25. Hasselbachia from Tizi Ibaouâne, bed 16. A - Hasselbachia gourara Ebbighausen et al., 2004, specimen MB.C.10234.1, lateral and ventral views, ×2. B - Hasselbachia gourara Ebbighausen et al., 2004, specimen MB.C.10234.2, dorsal and lateral views, $\times 3$. C - Hasselbachia arca $n$. sp., paratype MB.C.10233.2, dorsal and lateral views, $\times 2.5$. D - Hasselbachia arca n. sp., paratype MB.C.10233.4, lateral and dorsal views, $\times 2.5$. E - Hasselbachia arca n. sp., holotype MB.C.10233.1, $\times 2.5$. F - Hasselbachia arca n. sp., paratype MB.C.10233.3, lateral and dorsal views, $\times 2.5$. G - Hasselbachia sp., specimen MB.C.10235.1, dorsal and lateral views, $\times 2.5$. 


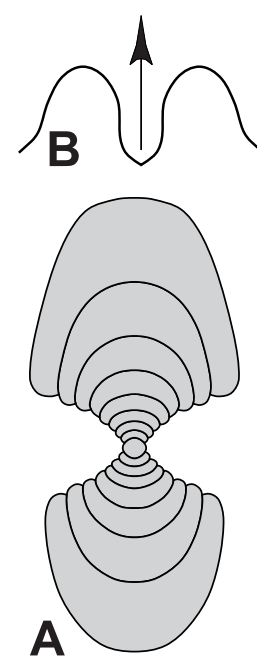

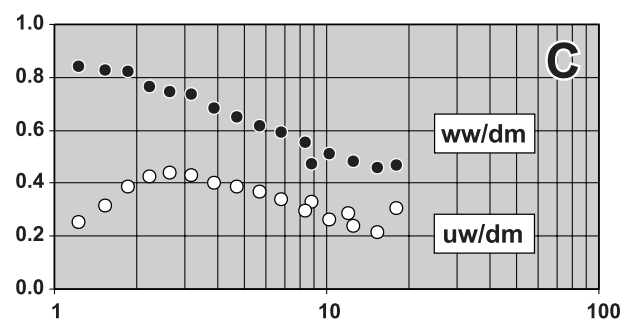

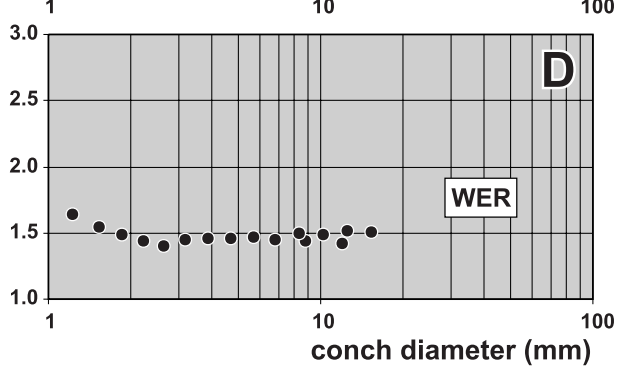

Fig. 26. Hasselbachia gourara Ebbighausen et al., 2004 from bed 16 of the Aguelmous. A - Cross section, specimen MB.C.10179; $\times 3$. B - Suture line (reversed), specimen MB.C.10234.2, at $8.6 \mathrm{~mm} \mathrm{dm}, 4.1 \mathrm{~mm}$ ww, $3.2 \mathrm{~mm}$ wh; $\times 5$. C - Ontogenetic development of the whorl width index (ww/dm) and umbilical width index (uw/dm). D - Ontogenetic development of the whorl expansion rate (WER). conch geometry, but possess much weaker steinkern constrictions. The suture line is similar to the type specimens; it has an adventive lobe that resembles the external lobe, but is slightly less deep.

\section{Hasselbachia arca $\mathbf{n}$. sp.}

Figs $25 \mathrm{C}-\mathrm{F}, 27$

Derivation of name. After the arc-shaped whorl cross section.

Holotype. Specimen MB.C.10233.1; illustrated here in Fig. 25E.

Type locality and horizon. Tizi Ibaouâne, Aguelmous (Ma'der, Anti-Atlas, Morocco); bed 16 (Early Tournaisian).

Material. Tizi Ibaouâne (bed 16): 25 specimens.

Diagnosis. Species of Hasselbachia with thinly pachyconic conch $(\mathrm{ww} / \mathrm{dm}=0.60-0.65$ at $10 \mathrm{~mm} \mathrm{dm})$. Inner whorls up to $5 \mathrm{~mm}$ diameter widely umbilicate (uw/dm 0.40 ), umbilicus narrower in later stages. Aperture very low, whorl expansion rate 1.50 . Steinkern with weak constrictions. Suture line with wide, parallel-sided external lobe and parallel-sided adventive lobe.

Description. The three cross sections MB.C.10233.5 - MB.C.10233.7 show very similar growth trajectories without remarkable variability in all growth stages (Fig. 27A-C). The conch becomes almost continuously slender during ontogeny, with a ww/dm ratio of 0.80 at $1-3 \mathrm{~mm} \mathrm{dm}$ to 0.60 at $10-12 \mathrm{~mm} \mathrm{dm}$. Distinct growth stages can not be separated. In contrast, the umbilicus shows a more complex development, with an opening from 0.20 in the initial stage to 0.40 at $3 \mathrm{~mm} \mathrm{dm}$, and thereafter a slight decrease to $0.35-0.40$ at $10 \mathrm{~mm} \mathrm{dm}$. The conch has a crescent-shaped whorl cross section throughout ontogeny, and a very low aperture (WER 1.45-1.50).

Specimen MB.C.10233.1 was chosen for holotype. It is a specimen with a $9 \mathrm{~mm}$ conch diameter and is a fully septate steinkern with some attached but strongly corroded shell remaining (Fig. 25E). It is thinly pachyconic $(\mathrm{ww} / \mathrm{dm}=0.65)$ with an umbilicus that has almost 0.40 of the conch diameter. Umbilical wall and umbilical margin are rounded. The specimen has two constrictions standing vis-àvis; they turn slightly back from the umbilicus and form a wide and shallow ventral sinus. The constrictions are faint on the shell surface but much more pronounced on the steinkern.
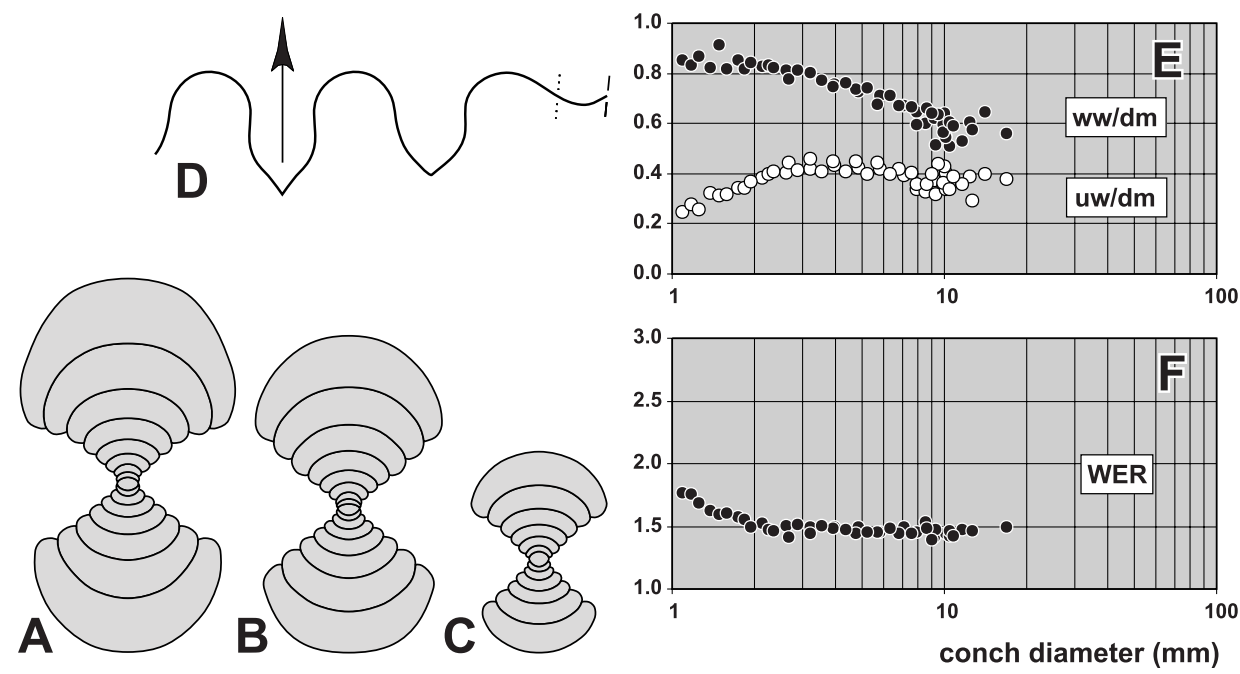

Fig. 27. Hasselbachia arca n. sp. from bed 16 of the Aguelmous. A - Cross section, paratype MB.C.10233.5; $\times 3$. B - Cross section, paratype MB.C.10233.6; ×3. C - Cross section, paratype MB.C.10233.7; ×3. D - Suture line, paratype MB.C.10233.4, at $9.6 \mathrm{~mm} \mathrm{dm}, 5.8 \mathrm{~mm} \mathrm{ww}$, $3.0 \mathrm{~mm}$ wh; $\times 6$. E - Ontogenetic development of the whorl width index (ww/dm) and umbilical width index (uw/dm). F - Ontogenetic development of the whorl expansion rate (WER). 

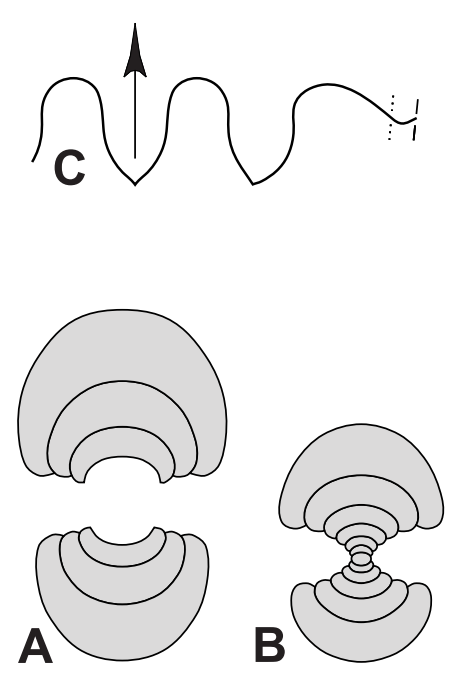
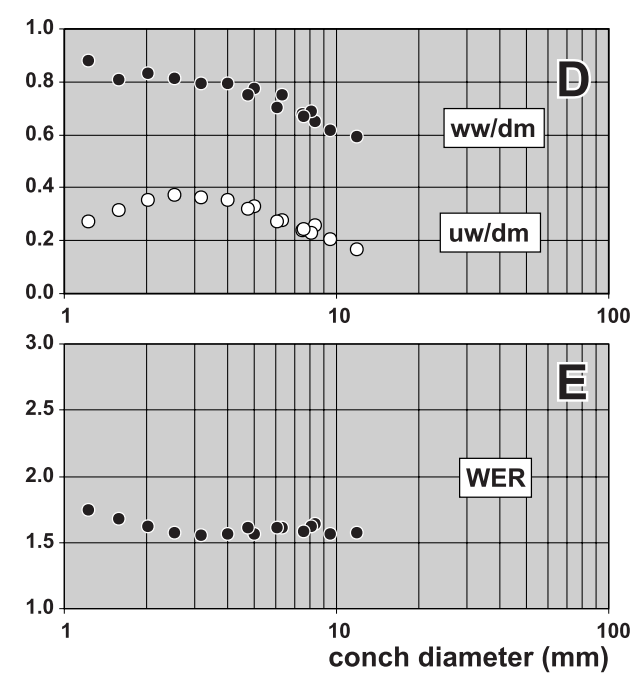

Fig. 28. Hasselbachia sp. from bed 16 of the Aguelmous. A - Cross section, specimen MB.C.10235.2; × 3. B - Cross section, specimen MB.C.10235.3; ×3. C - Suture line, specimen MB.C.10180, at $6.7 \mathrm{~mm} \mathrm{dm}$, $4.6 \mathrm{~mm}$ ww, $2.9 \mathrm{~mm}$ wh; $\times 7$. D - Ontogenetic development of the whorl width index (ww/dm) and umbilical width index (uw/dm). E - Ontogenetic development of the whorl expansion rate (WER).
All other specimens possess irregularly spaced, weak steinkern constrictions, which turn back on the flanks and extend with a very wide and shallow sinus across the venter. The course of the suture line is almost identical with that of H. gourara; there is a rather wide external lobe with parallel flanks in the upper half, a symmetric and broadly rounded ventrolateral saddle, and an adventive lobe that has almost the same shape as the external lobe (Fig. 27D).

Discussion. The new species closely resembles $H$. gourara but differs in the pachyconic conch that is 0.10 wider than in the latter species. Small individuals of $H$. arca always possess constrictions that appear not to be restricted to the steinkern. The two Rhenish species H. multisulcatum (Vöhringer, 1960) and H. gracile (Vöhringer, 1960) differ in the presence of deep and short constrictions on the flanks.

\section{Hasselbachia sp. Figs 25G, 28}

Material. Tizi Ibaouâne (bed 16): 3 specimens.

Remarks. The material is too incomplete for a distinct attribution to species. It has a somewhat intermediate position between $H$. gourara and $H$. arca, possessing a wider conch than the first and a narrower umbilicus than the second (Fig. 28D, E).

\section{Kornia n. gen.}

Type species. Kornia citrus n. sp.

Composition of the genus.

Kornia citrus n. sp.; Gattendorfia-Eocanites assemblage; AntiAtlas.

Imitoceras sphaeroidale Vöhringer, 1960; Gattendorfia Stufe, Rhenish Mountains.

"Paragattendorfia n. sp. 1" Korn \& Weyer, 2003; Gattendorfia Stufe, Rhenish Mountains.
Genus definition. Genus of the subfamily Acutimitoceratinae with pachyconic to globular conch. Innermost whorls evolute, umbilicus rapidly closing during ontogeny. Aperture always low, WER usually between 1.50 and 1.60.

Discussion. Korn \& Weyer (2003) included "Imitoceras sphaeroidale Vöhringer, 1960" in their new genus Hasselbachia, because of its low aperture as is seen in the two more characteristic species H. multisulcata (Vöhringer, 1960) and H. gracilis (Vöhringer, 1960). A characteristic of Hasselbachia is the constantly low aperture and the strong overlap of adult whorls, a feature that is not as well developed in "Imitoceras sphaeroidale Vöhringer, 1960". This species, which has the general conch shape of Acutimitoceras, but with a markedly lower aperture, possesses growth trajectories rather similar to the new species, and is therefore included here.

\section{Kornia citrus n. sp.}

Figs 29, 30

Derivation of name. After the genus Citrus, because of the lemon-shaped conch in the juvenile stage.

Holotype. Specimen MB.C.10165.1; illustrated here in Fig. 29B.

Type locality and horizon. Bou Tlidat, Aguelmous (Ma'der, Anti-Atlas, Morocco); bed 2 (Early Tournaisian).

Material. Bou Tlidat (bed 2): 4 specimens, Tazoult (bed 2): 3 specimens.

Diagnosis. Species of Kornia with conch spindle-shaped in the juvenile stage and globular in the adult stage. Umbilicus almost closed in stages larger than $7 \mathrm{~mm}$ conch diameter; conspicuous umbilical pad. Suture line with lanceolate external lobe and asymmetric adventive lobe. Steinkern without constrictions.

Description. The two sectioned specimens MB.C.10165.2 and MB.C.10202.1 (Fig. 30A, B) offer an insight into the conspicuous conch ontogeny up to $8 \mathrm{~mm}$ diameter. Growth starts with a short serpenticonic stage that ends at about $2 \mathrm{~mm}$ conch 

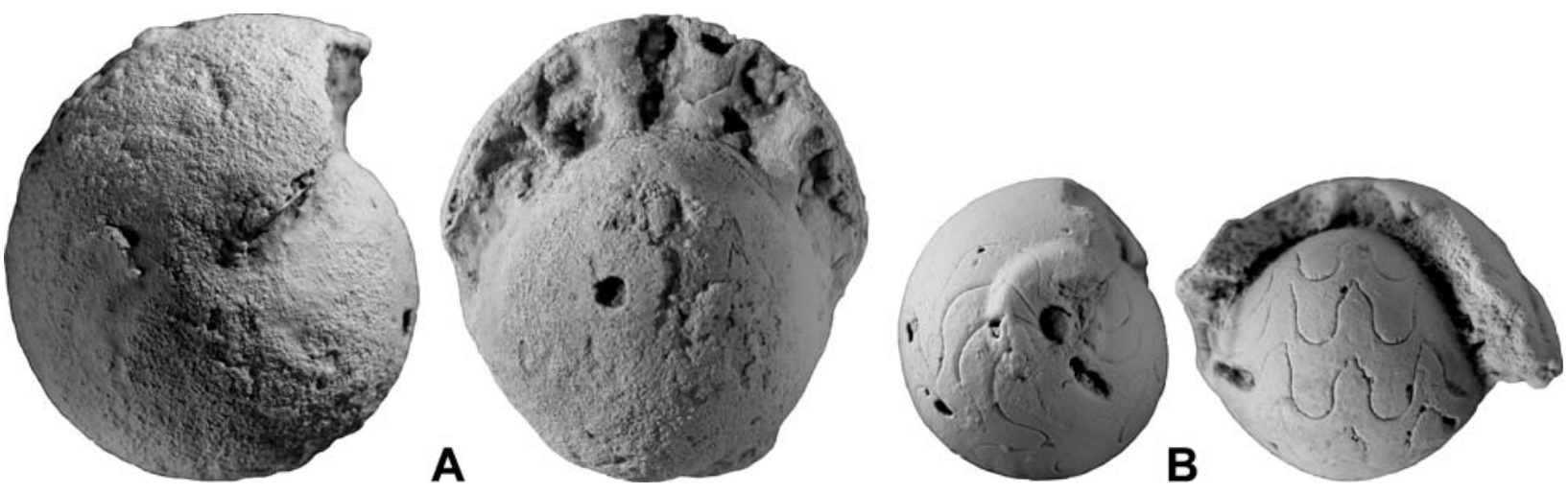

Fig. 29. Kornia citrus n. sp. from Bou Tlidat, bed 2. A - Paratype MB.C.10165.4, lateral and dorsal views, $\times 3$. B - Holotype MB.C.10165.1, lateral and dorsal views, $\times 5$.

diameter, followed by a rapid increase of the whorl width $(\mathrm{ww} / \mathrm{dm}=1.20-1.30$ at $5 \mathrm{~mm} \mathrm{dm})$, followed by a decrease in whorl width (Fig. 30E). Three whorls, from 3 to at least $8 \mathrm{~mm}$ conch diameter, are C-shaped with a pronounced umbilical rim, which separates the semicircular umbilical wall from the wide venter. The aperture is very low in all stages and results in a rather stable whorl expansion rate of approximately 1.50 (Fig. 30F).

Paratype MB.C.10165.4 has a $16 \mathrm{~mm}$ diameter and is the largest specimen of the species (Fig. 29A). It is globular $(\mathrm{ww} / \mathrm{dm}=0.90)$ with a nearly closed umbilicus, which exhibits the characteristic umbilical rim to a lesser degree than the sectioned smaller paratypes. The specimen is fully septate and encrusted by limonite; therefore, no details of the steinkern surface are visible. The suture line has a deep, lanceolate external lobe, a symmetric and rounded ventrolateral saddle, and a rather narrow, asymmetric adventive lobe with steep ventral and curved dorsal flank.

Holotype MB.C.10165.1 (Fig. 29B) is a spindleshaped steinkern of $6.5 \mathrm{~mm} \mathrm{dm}$ and has a very low aperture. The umbilical rim is very well visi- ble and forms a thick round pad. The steinkern is smooth. Suture lines were drawn from paratypes MB.C.10165.3 and MB.C.10202.2 (Fig. 30C, D), both at approximately $6.5 \mathrm{~mm}$ conch diameter. They differ somewhat in the width of the lobes but possess like the holotype, a lanceolate external lobe, a continuously rounded, symmetric ventrolateral saddle, and an asymmetric adventive lobe.

Discussion. The new species can easily be separated from any other ammonoid from the Gattendorfia faunas by its umbilical pad. Similar growth trajectories can be seen only in "Imitoceras sphaeroidale Vöhringer, 1960" which however, has a wider umbilicate juvenile stage. An ammonoid similar to Kornia citrus was figured by Korn \& Weyer (2003, pl. 2: fig. 20, 21) as "Paragattendorfia n. sp. 1". This specimen from Oese in the Rhenish Mountains has a globe shape with a very low aperture and a very narrow umbilicus. It has growth lines which turn strongly back from the slightly elevated umbilical margin. In conch shape and form of the umbilicus, the taxon in open nomenclature resembles the new species and may belong to the genus Kornia.
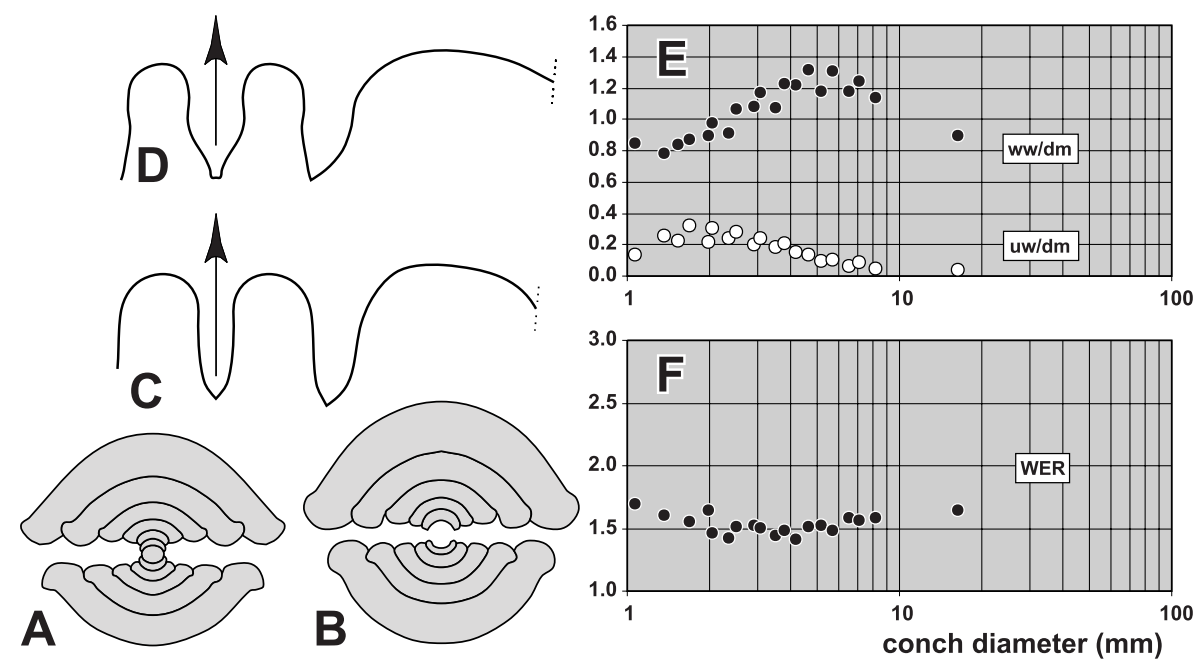

Fig. 30. Kornia citrus n. sp. from bed 2 of the Aguelmous. A Cross section, paratype MB.C.10165.2; ×3. B - Cross section, paratype MB.C.10202.1; $\times 3$. C - Suture line, paratype MB.C.10165.3, at $6.3 \mathrm{~mm} \mathrm{dm}$, ca. $3.4 \mathrm{~mm}$ wh; $\times 7$. D - Suture line, paratype MB.C.10202.2, at $7.1 \mathrm{~mm}$ ww, $3.0 \mathrm{~mm}$ wh; $\times 7$. E Ontogenetic development of the whorl width index (ww/dm) and umbilical width index (uw/dm). F - Ontogenetic development of the whorl expansion rate (WER). 
Subfamily Imitoceratinae Ruzhencev, 1950

\section{Imitoceras Schindewolf, 1923}

Type species. Goniatites Ixion Hall, 1860.

\section{Imitoceras oxydentale Bockwinkel \& Ebbighausen, 2006}

Figs $31 \mathrm{~A}-\mathrm{D}, 32$

* 2006 Imitoceras oxydentale Bockwinkel \& Ebbighausen: 108, figs 24C, D, G, H, 25.

Material. Bou Tlidat (bed 2): 17 specimens, Bou Tlidat (bed 12): 1 specimen, Tazoult (bed 2): 2 specimens, Tazoult (loose): 6 specimens, Tizi Ibaouâne (bed 2): 13 specimens, Tizi Malilane (bed 2): 2 specimens.

Re marks. Little can be added to the original description of the species. The new material differs from the material from the type locality in the slightly less evolute inner whorls, but this difference is regarded as intraspecific variability. The suture line of specimen MB.C.10242 has a rather strongly pouched external lobe with sinuous flanks (Fig. 32D), and differs in this respect from a paratype of about the same size from Mfis.

\section{Imitoceras sp.}

Figs 31E, 33
Description. The cross section of specimen MB.C.10187.2 displays six whorls, which permit the study of ontogeny up to $38 \mathrm{~mm}$ conch diameter (Fig. 33A). During this interval, there is an almost continuous decrease in the ww/dm ratio from 0.95 to 0.40 . The umbilicus opens in the juvenile stage to one fifth of the conch diameter at $2-3 \mathrm{~mm} \mathrm{dm}$, but then closes rather rapidly and remains punctiform. Flanks and venter are rounded at $38 \mathrm{~mm} \mathrm{dm}$, and the conch there is widest in the midflank area. The aperture becomes higher during ontogeny; the whorl expansion rate is rather low up to $4 \mathrm{~mm} \mathrm{dm}$ (WER $=1.80)$, then increases to a value of 2.20 at $10 \mathrm{~mm} \mathrm{dm}$, and then remains at this level. The suture line of the specimen has a small, pouched external lobe, a 1.5 times deeper, asymmetric adventive lobe, and a broadly rounded ventrolateral saddle in between them.

Discussion. The material is too poor to be described as a distinct species. It is clear from conch shape and suture line, however, that it belongs to Imitoceras.

Family Gattendorfiidae Bartzsch \& Weyer, 1987 Subfamily Gattendorfiinae Bartzsch \& Weyer, 1987

\section{Gattendorfia Schindewolf, 1920}
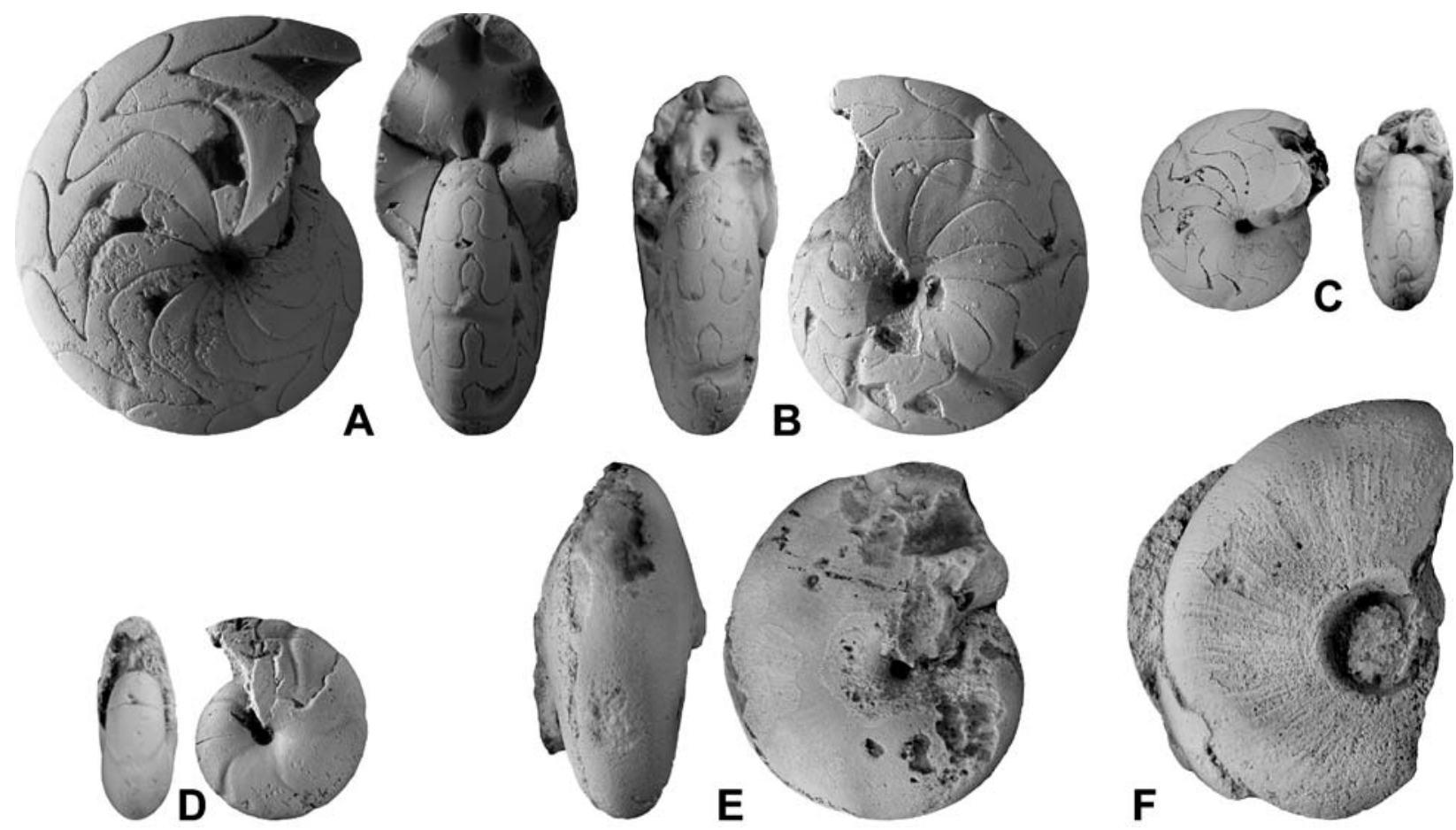

Fig. 31. Imitoceras and Gattendorfia from Fezzou. A - Imitoceras oxydentale Bockwinkel \& Ebbighausen, 2006, specimen MB.C.10162.1 from Bou Tlidat, bed 2, lateral and dorsal views, $\times 4$. B - Imitoceras oxydentale Bockwinkel \& Ebbighausen, 2006, specimen MB.C.10162.2 from Bou Tlidat, bed 2, dorsal and lateral views, $\times 3$. C - Imitoceras oxydentale Bockwinkel \& Ebbighausen, 2006, specimen MB.C.10162.3 from Bou Tlidat, bed 2, lateral and dorsal views, $\times 3$. D - Imitoceras oxydentale Bockwinkel \& Ebbighausen, 2006, specimen MB.C.10162.1 from Bou Tlidat, bed 2, dorsal and lateral views, $\times 4$. E - Imitoceras sp., specimen MB.C.10187.1 from Rich el Mbidia, bed 18, ventral and lateral views, $\times 1.25$. F - Gattendorfia sp., specimen MB.C.10189 from Rich el Mbidia, bed 18, lateral view, $\times 1$. 

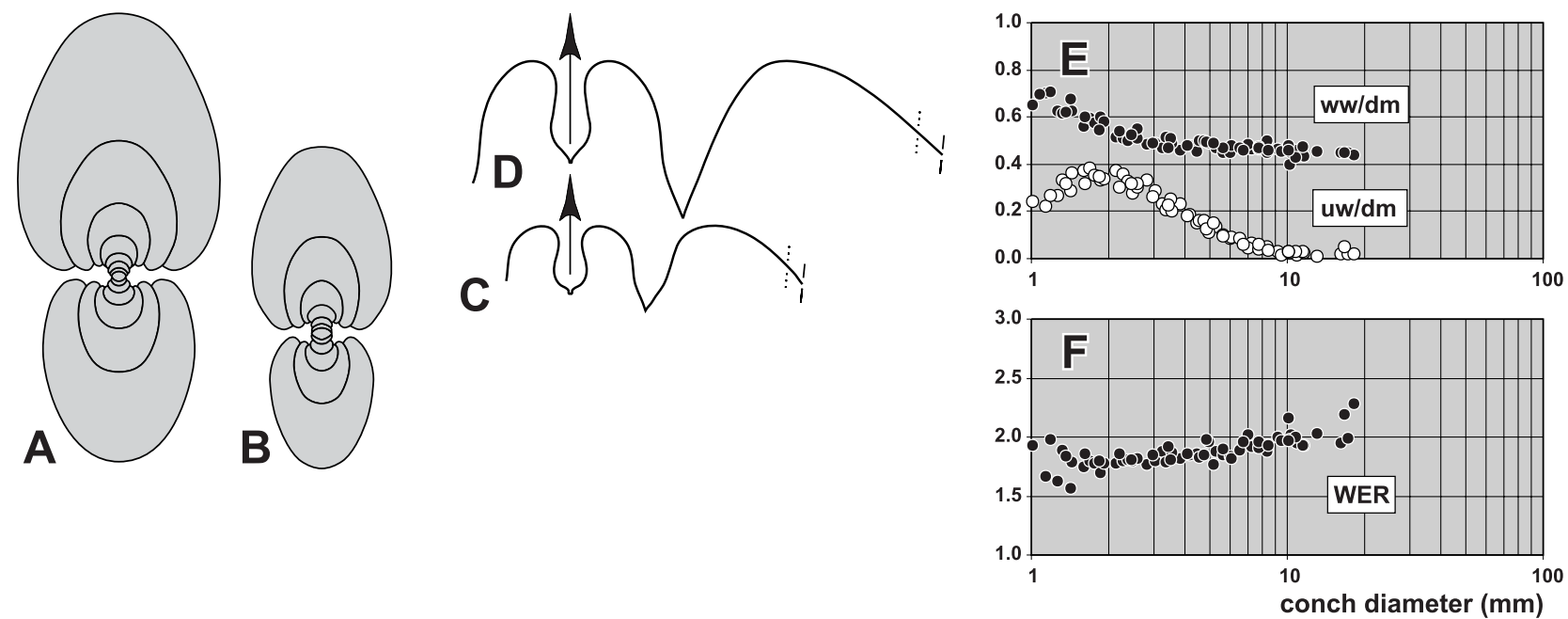

Fig. 32. Imitoceras oxydentale Bockwinkel \& Ebbighausen, 2006 from bed 2 of the Aguelmous. A - Cross section, specimen MB.C.10200.1; $\times 3$. B - Cross section, specimen MB.C.10162.4; $\times 3$. C - Suture line, specimen MB.C.10220, at $9.9 \mathrm{~mm} \mathrm{dm}$, $4.7 \mathrm{~mm}$ ww, $5.5 \mathrm{~mm}$ wh; $\times 4$. D - Suture line, specimen MB.C. 10242 , at $16.4 \mathrm{~mm} \mathrm{dm}, 8.3 \mathrm{~mm}$ ww, $9.5 \mathrm{~mm}$ wh; $\times 4$. E - Ontogenetic development of the whorl width index (ww/dm) and umbilical width index (uw/dm). F - Ontogenetic development of the whorl expansion rate (WER).
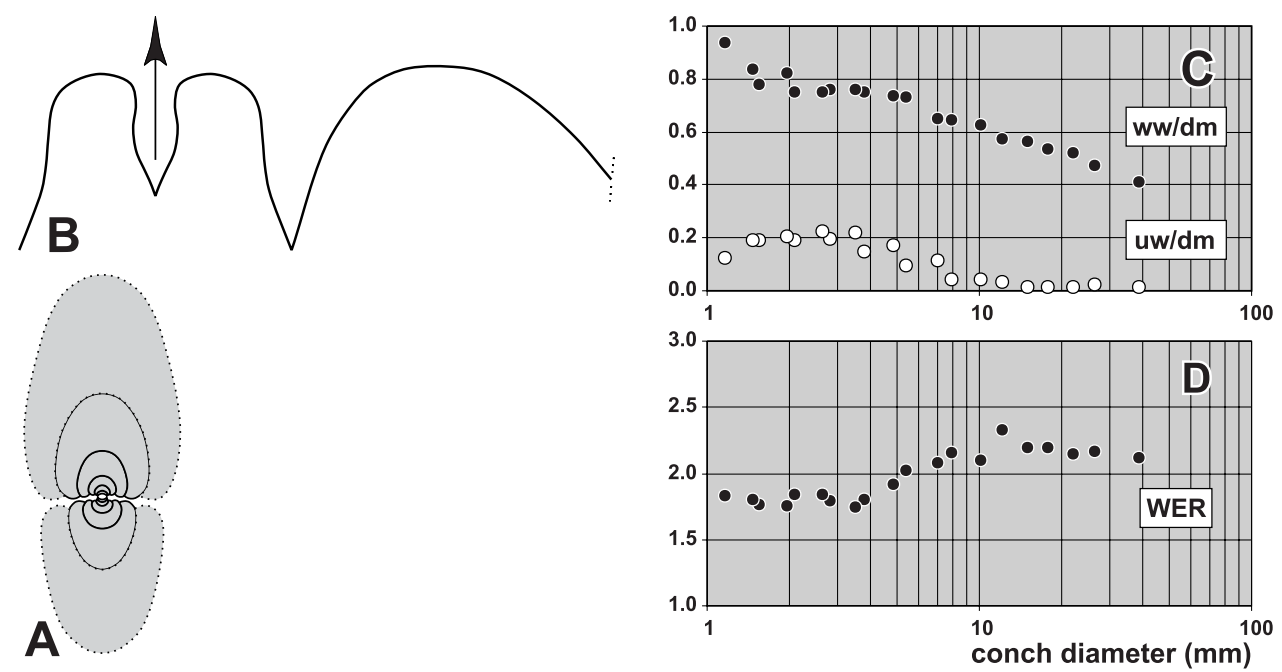

Fig. 33. Imitoceras sp. from bed 18 of the Aguelmous. A - Cross section, specimen MB.C.10187.2; $\times 1$. B - Suture line (reversed), specimen MB.C.10187.3, at $29.1 \mathrm{dm}, 13.3 \mathrm{~mm}$ ww, $17.3 \mathrm{~mm}$ wh; $\times 3$. C - Ontogenetic development of the whorl width index (ww/dm) and umbilical width index (uw/dm). D - Ontogenetic development of the whorl expansion rate (WER).

Fig. 34. Gattendorfia from Fezzou. A - Gattendorfia jacquelinae Ebbighausen et al. 2004, specimen MB.C.10232.1 from Tizi Ibaouâne, bed 16, lateral and ventral views, $\times 1$. B - Gattendorfia jacquelinae Ebbighausen et al. 2004, specimen MB.C.10232.2 from Tizi Ibaouâne, bed 16, lateral and ventral views, $\times 3$. C - Gattendorfia jacquelinae Ebbighausen et al. 2004, specimen MB.C.10224.1 from Tizi Ibaouâne, bed 12, dorsal and lateral views, $\times 3$. D - Gattendorfia jacquelinae Ebbighausen et al. 2004, specimen MB.C.10232.3 from Tizi Ibaouâne, bed 12, lateral and dorsal views, $\times 1$. E - Gattendorfia debouaaensis (Bockwinkel \& Ebbighausen, 2006), specimen MB.C.10175.4 from Rich el Mbidia, bed 16, dorsal and lateral views, $\times 1$. F - Gattendorfia debouaaensis (Bockwinkel \& Ebbighausen, 2006), specimen MB.C.10230.1 from Tizi Ibaouâne, bed 16, lateral and dorsal views, $\times 1$. G - Gattendorfia debouaaensis (Bockwinkel \& Ebbighausen, 2006), specimen MB.C.10230.2 from Tizi Ibaouâne, bed 16, lateral and ventral views, $\times 2.5$. H - Gattendorfia lhceni n. sp., holotype MB.C.10225.1 from Tizi Ibaouâne, bed 12, lateral and dorsal views, $\times 1$. I - Gattendorfia lhceni n. sp., paratype MB.C.10225.2 from Tizi Ibaouâne, bed 12, dorsal and lateral views, $\times 1.25$. J - Gattendorfia lhceni n. sp., paratype MB.C.10225.3 Tizi Ibaouâne, bed 12, lateral and ventral views, $\times 1.5$. K - Gattendorfia lhceni n. sp., specimen MB.C.10225.4 Tizi Ibaouâne, bed 12, dorsal and lateral views, $\times 2.5$. L - Gattendorfia lhceni n. sp., specimen MB.C.10168.1 Bou Tlidat, bed 12, lateral and dorsal views, $\times 2.5$. M - Gattendorfia lhceni n. sp., specimen MB.C.10168.2 from Bou Tlidat, bed 12, lateral and dorsal views, $\times 2.5$. N - Gattendorfia gisae $\mathrm{n}$. sp., paratype MB.C.10211 from Tazoult, bed unknown, ventral and lateral views, $\times 1.25$. O - Gattendorfia debouaaensis (Bockwinkel \& Ebbighausen, 2006), specimen MB.C.10175.3 from Rich el Mbidia, bed 16, dorsal and lateral views, $\times 1.25$. 

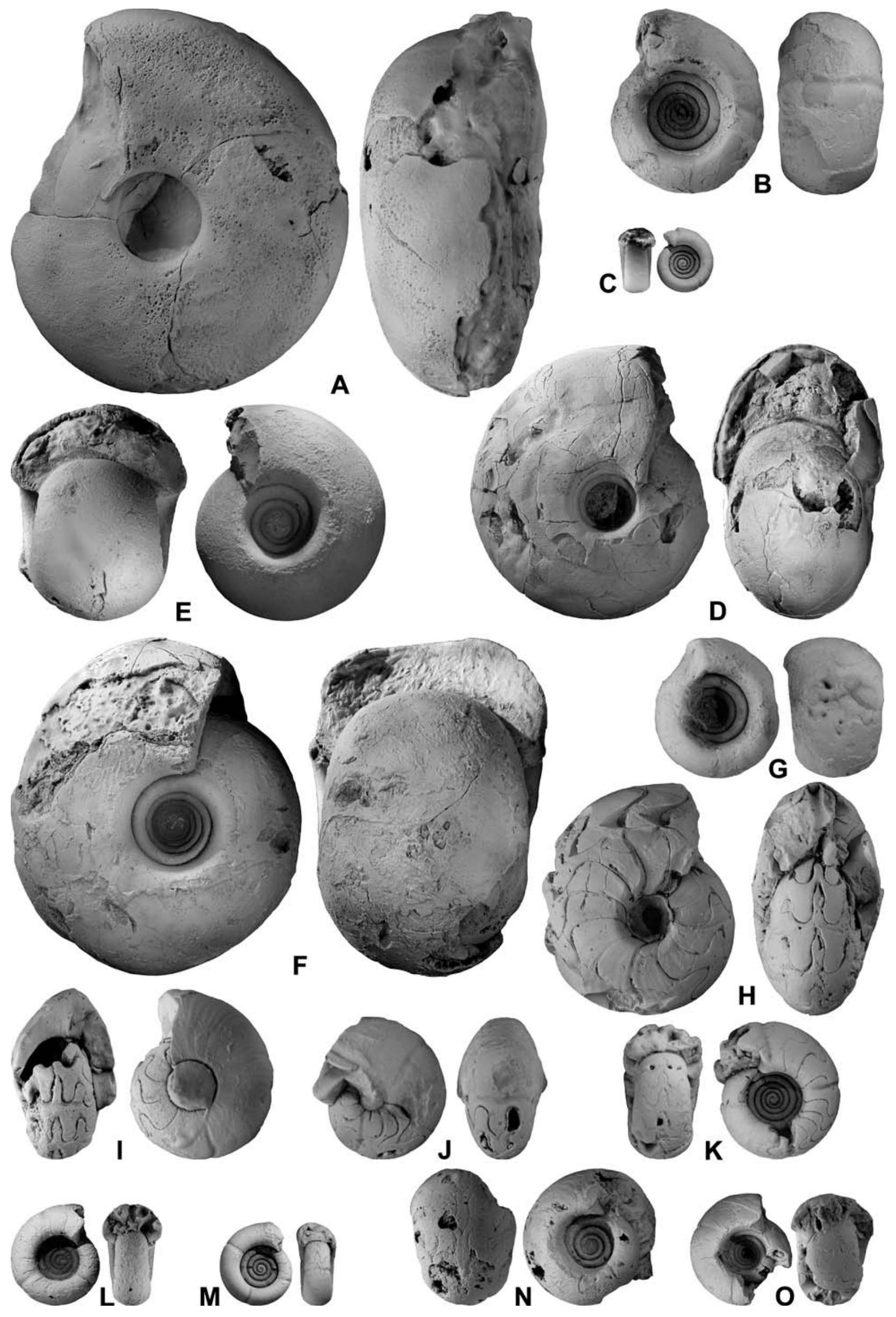
Gattendorfia jacquelinae Ebbighausen, Bockwinkel, Korn \& Weyer, 2004

Figs $34 \mathrm{~A}-\mathrm{D}, 35$

* 2004 Gattendorfia jacquelinae Ebbighausen, Bockwinkel, Korn \& Weyer: 142, figs 11-13.

2006 Gattendorfia jacquelinae. - Bockwinkel \& Ebbighausen: 111 , figs $27 \mathrm{~A}-\mathrm{F}, 28$.

Material. Bou Tlidat (bed 2): 4 specimens, Bou Tlidat (bed 12): 2 specimens, Tazoult (bed 2): 1 specimen, Rich El Mbidia (bed 16): 2 specimens, Tizi Ibaouâne (bed 12): 2 specimens, Tizi Ibaouâne (bed 16): 7 specimens.

Description. The new material is composed of small and large specimens, and hence the description can be extended. Cross section MB.C.10232.4 of a specimen with $33 \mathrm{~mm}$ diameter shows the transition from the serpenticonic juvenile stage to the cadyconic intermediate and then pachyconic adult stage (Fig. 35A). The umbilicus reaches a maximum of 0.60 at $4-7 \mathrm{~mm}$ conch diameter, and a subsequent decrease to 0.35 at $33 \mathrm{~mm} \mathrm{dm}$. The absolute width of the umbilicus increases constantly, and the umbilical wall, convexly rounded in juvenile and intermediate stages, turns to become flattened and steep on the last volution.

MB.C.10232.3 is a corroded specimen of $52 \mathrm{~mm}$ conch diameter; it is thinly pachyconic $(\mathrm{ww} / \mathrm{dm}=$ 0.63 ) with an umbilicus of one fourth of the conch diameter (Fig. 34D). Flanks and venter are broadly rounded, and the umbilical margin appears to be subangular. The specimen has fine convex growth lines which form a deep sinus on the venter. Specimen MB.C.10232.1 (73 $\mathrm{mm} \mathrm{dm})$ is the largest among the material; it is a corroded fragment but shows that the umbilicus, $16.5 \mathrm{~mm}$ wide, is opened in the adult stage (Fig. 34A).
Discussion. The conch of $G$. jacquelinae is similar to that of $G$. costata Vöhringer, 1960, but lacks the ribbing of that species. G. crassa is another similar species, but the size of its umbilicus stagnates in its opening in the adult stage, whereas it slowly but constantly opens in G.jacquelinae. Furthermore, G. crassa has juvenile whorls with slightly flattened venter, unlike the rounded venter of G. jacquelinae. The ontogenetic trajectories of both species differ in respect to conch width and umbilical width indices. G. crassa has a much thinner juvenile stage $(w w / d m=0.30-0.40$ at $4 \mathrm{~mm} \mathrm{dm}$; see Korn \& Vöhringer 2004) compared to $G$. jacquelinae (ww/dm = $0.45-0.55$ at $4 \mathrm{~mm} \mathrm{dm}$ ), and a wider umbilicus (uw/dm >0.60).

\section{Gattendorfia debouaaensis (Bockwinkel \& Ebbig- hausen, 2006)}

Figs $34 \mathrm{E}-\mathrm{G}, \mathrm{O}, 36$

* 2006 Zadelsdorfia debouaaensis Bockwinkel \& Ebbighausen: 115 , figs $30 \mathrm{I}-\mathrm{N}, 33$.

Material. Rich El Mbidia (bed 16): 11 specimens, Tizi Ibaouâne (bed 16): 24 specimens.

Diagnosis. Species of Gattendorfia with thickly pachyconic conch in the adult stage $(\mathrm{ww} / \mathrm{dm}=0.75-0.85)$. Inner whorls up to $6 \mathrm{~mm}$ diameter widely umbilicate (uw/dm $0.50-0.60$ ), umbilicus slightly narrower (uw/dm 0.40 ) at $15 \mathrm{~mm}$ diameter. Aperture low, whorl expansion rate 1.50-1.60 without an increase in the adult stage. Umbilical margin subangular. Steinkern without constrictions, smooth. Suture line with moderately wide, slightly pouched external lobe and symmetric lanceolate adventive lobe.

Description. The diagnosis can be emended on the basis of more and better preserved material.
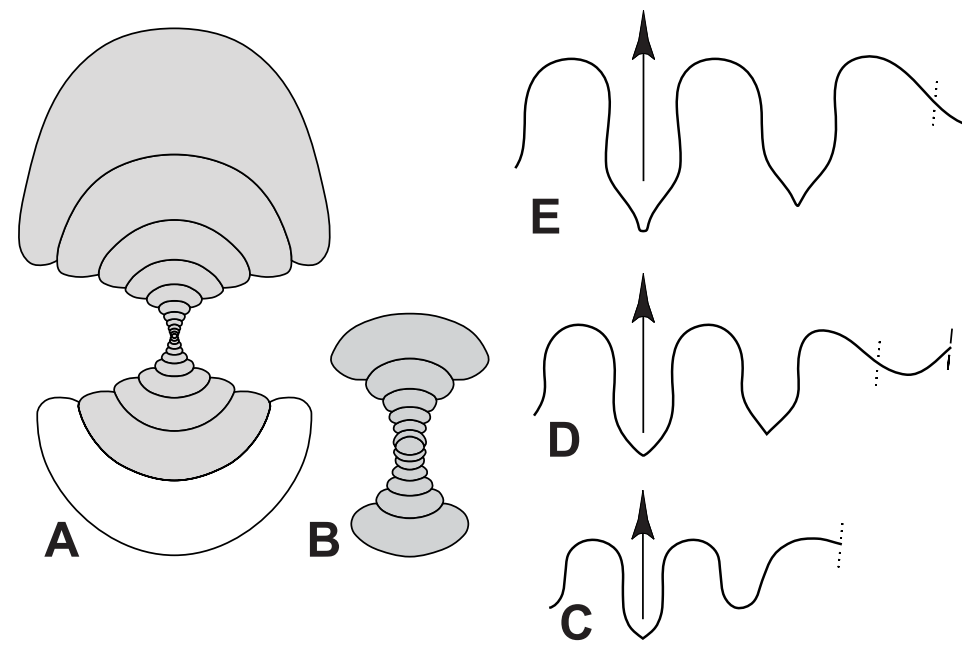
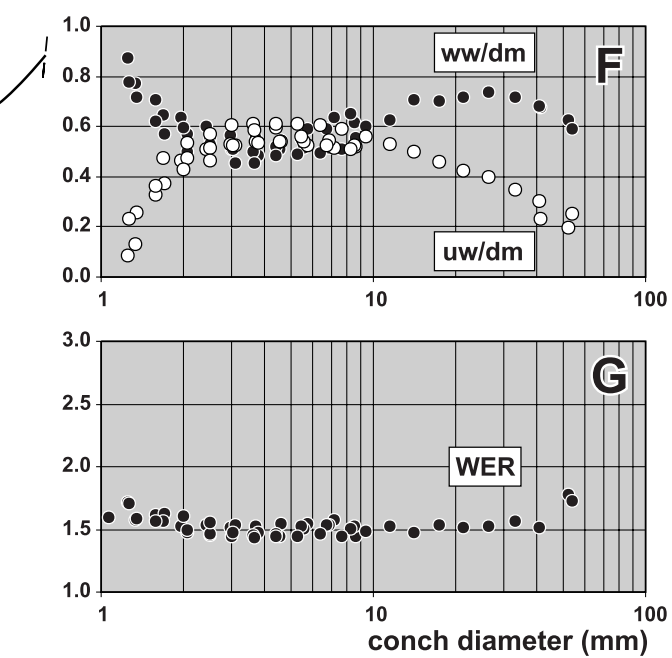

Fig. 35. Gattendorfia jacquelinae Ebbighausen et al., 2004 from bed 2 and bed 16 of the Aguelmous. A - Cross section, specimen MB.C.10232.4; bed 16; $\times 1$. B - Cross section, specimen MB.C.10177.1; bed 2; $\times 3$. C - Suture line, specimen MB.C.10177.2, at $8.5 \mathrm{~mm} \mathrm{dm}, 5.2 \mathrm{~mm}$ ww, $2.1 \mathrm{~mm}$ wh; $\times 7$; bed 2. D - Suture line, specimen MB.C.10161.1, at $3.8 \mathrm{~mm}$ ww, $2.3 \mathrm{~mm}$ wh; $\times 7$; bed 2. E - Suture line, specimen MB.C.10161.2, at $7.3 \mathrm{~mm}$ ww, $2.6 \mathrm{~mm} \mathrm{wh}$; $\times 7$; bed 2. F - Ontogenetic development of the whorl width index (ww/dm) and umbilical width index (uw/dm). G - Ontogenetic development of the whorl expansion rate (WER). 

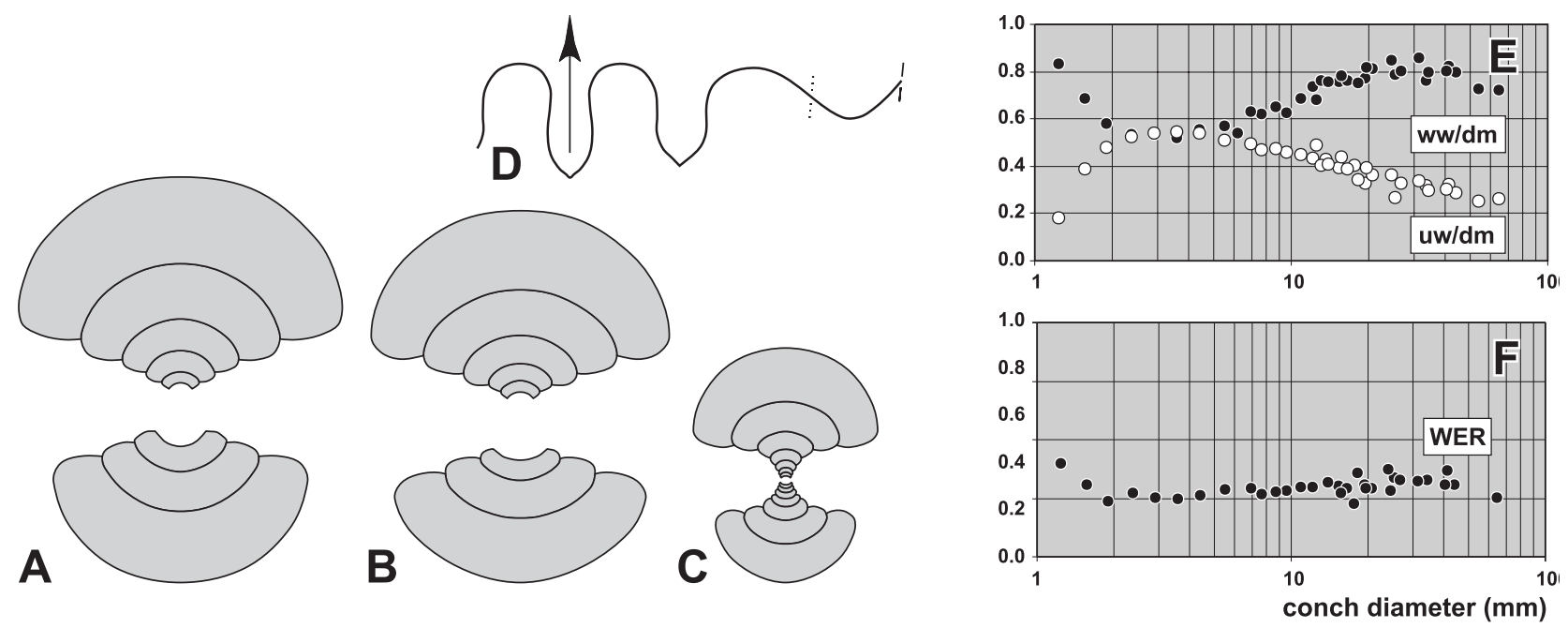

Fig. 36. Gattendorfia debouaaensis (Bockwinkel \& Ebbighausen, 2006) from bed 16 of the Aguelmous. A - Cross section, specimen MB.C.10175.1; $\times 1$. B - Cross section, specimen MB.C.10230.3; $\times 1$. C - Cross section, specimen MB.C.10175.2; $\times 1$. D - Suture line, specimen MB.C.10175.3, at $15.1 \mathrm{~mm} \mathrm{dm}, 10.8 \mathrm{~mm}$ ww, $4.1 \mathrm{~mm}$ wh; $\times 4$. E - Ontogenetic development of the whorl width index $(\mathrm{ww} / \mathrm{dm})$ and umbilical width index $(\mathrm{uw} / \mathrm{dm}) . \mathbf{F}$ - Ontogenetic development of the whorl expansion rate (WER).

The cross sections MB.C.10175.1, MB.C.10230.3, and MB.C.10175.2 provide insight into the ontogenetic development that as is characteristic for the genus Gattendorfia, shows rather distinct growth intervals (Fig. 36A-C), beginning with a serpenticonic early juvenile stage (ending at $8-10 \mathrm{~mm} \mathrm{dm}$ ), and then transforming into a pachyconic stage. The aperture is low throughout ontogeny, with a slow increase of the whorl expansion rate from 1.50 at $2 \mathrm{~mm} \mathrm{dm}$ to 1.60 at $20-40 \mathrm{~mm} \mathrm{dm}$.

Large specimens such as MB.C.10175.4 $(40 \mathrm{~mm}$ conch diameter) appear to be smoothshelled without constrictions or strengthened growth lines (Fig. 34E). The specimen is a thickly pachyconic conch $(\mathrm{ww} / \mathrm{dm}=0.82)$ with a moderately narrow umbilicus $(\mathrm{uw} / \mathrm{dm}=0.32)$ that is bordered on the flanks by a subangular umbilical edge.

The suture line of specimen MB.C.10175.3 shows a lanceolate, slightly pouched external lobe, which is deeper than the similar adventive lobe (Fig. 36D). Both lobes are separated by an almost symmetric, broadly arched ventrolateral saddle.

Discussion. G. debouaaensis belongs to a species of the genus in which the adult stage is obviously not becoming slender, and in this trait differs from species such as G. crassa Vöhringer, 1960, G. lhaceni n. sp., and G. jacquelinae Ebbighausen, Bockwinkel, Korn \& Weyer, 2004. G. gisae n. sp. has also a thickly pachyconic adult stage, but differs in the rounded umbilical margin and the higher aperture (WER $=2.00$ at $40 \mathrm{~mm} \mathrm{dm}$ ) from $G$. debouaaensis.

Korn \& Feist (2007) showed that the genera Gattendorfia Schindewolf, 1920 and Zadelsdorfia Weyer, 1972 cannot be separated, and that the latter has to be treated as a junior synonym. The putative difference between them has been the shape of the external lobe, which is lanceolate in Gattendorfia and pouched in Zadelsdorfia. The North African mate- rial, however, provides firm evidence that a pouched lobe is present in most of the Gattendorfia species.

\section{Gattendorfia lhceni n. sp.} Figs $34 \mathrm{H}-\mathrm{M}, 37$

Derivation of name. After our friend Lhcen Mahraz from Fezzou, to honour his contribution during field work.

Holotype. Specimen MB.C.10225.1; illustrated here in Fig. 34H.

Type locality and horizon. Tizi Ibaouâne (A), Aguelmous (Ma'der, Anti-Atlas, Morocco); bed 12 (Early Tournaisian).

Material. Bou Tlidat (bed 12): 3 specimens, Tizi Ibaouâne (bed 12): 28 specimens.

Diagnosis. Species of Gattendorfia with discoidal to pachyconic conch. Inner whorls up to $8 \mathrm{~mm}$ diameter widely umbilicate (uw/dm 0.55-0.60), umbilicus narrower (uw/dm $0.25-0.30)$ at $15 \mathrm{~mm}$ diameter. Aperture low, whorl expansion rate $1.50-1.60$, increasing to 1.90 in the adult stage. Umbilical margin subangular. Steinkern with rursiradiate constrictions and faint riblets. Suture line with very narrow, slightly pouched external lobe and symmetric adventive lobe.

Description. The growth trajectories show a complex picture, and the conch parameters are correlated to some degree (Fig. 37G, H). The conch is globular in the initial stage $(\mathrm{ww} / \mathrm{dm}=0.80-0.95$ at $1 \mathrm{~mm} \mathrm{dm})$, rapidly becoming discoidal $(\mathrm{ww} / \mathrm{dm}=$ $0.40-0.50$ at $3-4 \mathrm{~mm} \mathrm{dm}$ ), then becoming thicker again $(\mathrm{ww} / \mathrm{dm}=0.55-0.65$ at $10 \mathrm{~mm} \mathrm{dm})$, and finally, being thickly discoidal in the adult stage $(\mathrm{ww} / \mathrm{dm}=$ 0.50 at $45 \mathrm{~mm} \mathrm{dm}$ ). This development is paralleled by changes in the umbilical width, with a uw/dm ratio of $0.55-0.65$ at $3-6 \mathrm{~mm} \mathrm{dm}$, a subsequent reduction to a value of 0.20 at $16 \mathrm{~mm} \mathrm{dm}$, and maintenance of this ratio in the adult stage. The aperture is low in early growth stages (WER $=1.50-1.60$ up to $4 \mathrm{~mm} \mathrm{dm}$ ), and thereafter almost continuously increases to 1.90 in adults. 

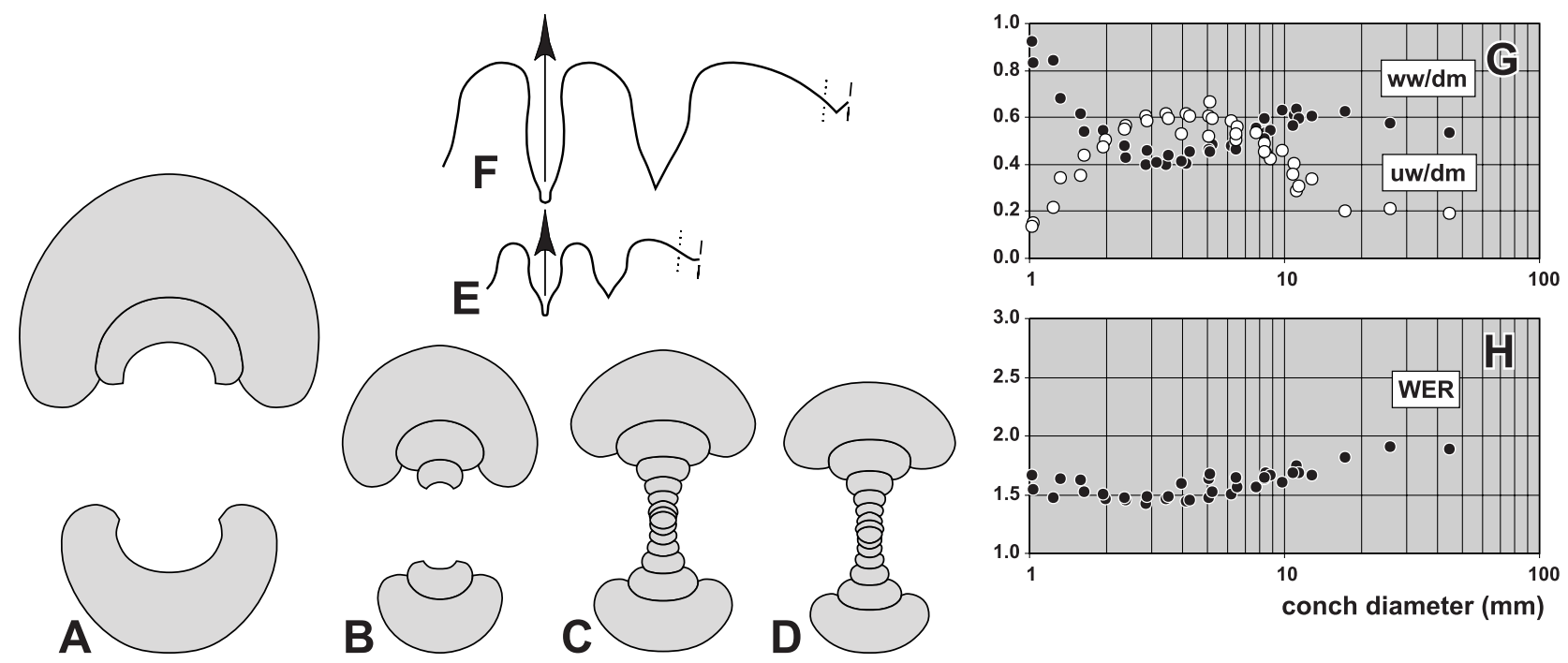

Fig. 37. Gattendorfia lhceni n. sp. from bed 12 of the Aguelmous. A - Cross section, paratype MB.C.10225.5; × 3. B - Cross section, paratype MB.C.10225.6; ×3. C - Cross section, paratype MB.C.10225.7; $\times 3$. D - Cross section, paratype MB.C.10225.8; $\times 3$. E - Suture line, paratype MB.C.10225.6, at $6.2 \mathrm{~mm}$ ww, $3.5 \mathrm{~mm}$ wh; $\times 3$. F - Suture line, holotype MB.C.10225.1, at $16.5 \mathrm{~mm}$ ww, $13.3 \mathrm{~mm}$ wh; $\times 2$. G - Ontogenetic development of the whorl width index (ww/dm) and umbilical width index (uw/dm). H - Ontogenetic development of the whorl expansion rate (WER).

Holotype MB.C.10225.1 is a rather well-preserved steinkern of $44 \mathrm{~mm} \mathrm{dm}$; it is fully chambered with 12 septa, which do not show crowding (Fig. $34 \mathrm{H})$. The conch is thickly discoidal (ww/dm = 0.53 ) and widest at the pronounced subangular umbilical edge. The umbilical width is one fifth of the conch diameter. The steinkern has a few feeble constrictions, which turn backwards from the umbilicus. Between them, a faint ribbing is visible on the inner flanks. In the suture line of the holotype, the very narrow, slightly inflated external lobe is most conspicuous on the flank, followed by an almost symmetric ventrolateral saddle and an almost symmetric adventive lobe with subparallel flanks in the upper half (Fig. 37F).

Paratype MB.C.10225.2 is smaller $(26 \mathrm{~mm} \mathrm{dm})$ but resembles the holotype in conch shape and steinkern ornament (Fig. 34I). The riblets are stronger in this specimen.

The juvenile specimens show a completely different conch morphology, as visible in the cross sections and the plots of the growth trajectories. Paratype MB.C.10225.4 (10.5 mm dm), for instance, has an open umbilicus (uw $/ \mathrm{dm}=0.37$ ) and ventrally depressed whorls. It has four rather strong steinkern constrictions, which extend almost linearly across the flanks and form a shallow sinus on the venter (Fig. 34K).

Discussion. Gattendorfia lhceni n. sp. resembles G. crassa Vöhringer, 1960 in its conch dimensions and ontogenetic development. The main difference is the much narrower external lobe in the new species which serves as a distinguishing criterion with most other species of Gattendorfia. G. asiatica Librovitch, 1940 has a similar conch morphology and external lobe, but possesses a strikingly asymmetric adventive lobe and linear constrictions.

\section{Gattendorfia gisae n. sp.}

Figs $34 \mathrm{~N}, 38$

Derivation of name. After Gisa Bockwinkel, who participated in some of the field campaigns to Morocco, and encouraged the present study.

Holotype. Specimen MB.C.10176.1; illustrated here in 38A, D.

Type locality and horizon. Tizi Ibaouâne (A), Aguelmous (Ma'der, Anti-Atlas, Morocco); bed 12 (Early Tournaisian).

Material. Tazoult (loose): 1 specimen, Rich El Mbidia (bed 16): 8 specimens, Tizi Ibaouâne (bed 16): 13 specimens.

Diagnosis. Species of Gattendorfia with thickly pachyconic conch in the adult stage $(\mathrm{ww} / \mathrm{dm}=0.75-0.85)$. Inner and intermediate whorls up to $12 \mathrm{~mm}$ diameter moderately widely umbilicate (uw/dm 0.35-0.40), umbilicus slightly narrower (uw/dm 0.30) at $15-30 \mathrm{~mm}$ diameter. Aperture low in the juvenile stage, whorl expansion rate $1.50-1.60$, increasing in the adult stage to 2.00. Umbilical margin rounded. Steinkern without constrictions, smooth. Suture line with narrow, slightly pouched external lobe and symmetric lanceolate adventive lobe.

Description. Cross sections MB.C.10176.1 and MB.C.10231.1 display the development of conch geometry, which is normal for a species of Gattendorfia (Fig. 38A, B). A distinct serpenticonic stage does not exist; the inner whorls are slightly more evolute than the outer, but the uw/dm ratio does not exceed a value of 0.40 . The conch is pachyconic in all stages, with a ww/dm ratio of 0.70 at $6 \mathrm{~mm}$ conch diameter, increasing to 0.80 in later stages. All growth stages show a similar kidney-shaped whorl cross section, but the apertural height increases rather quickly from 1.60 at $10 \mathrm{~mm} \mathrm{dm}$ to 2.00 at $30 \mathrm{~mm} \mathrm{dm}$. The umbilical wall is rounded throughout ontogeny.

The sectioned specimen MB.C.10176.1 was chosen for the holotype; it shows the conch development 

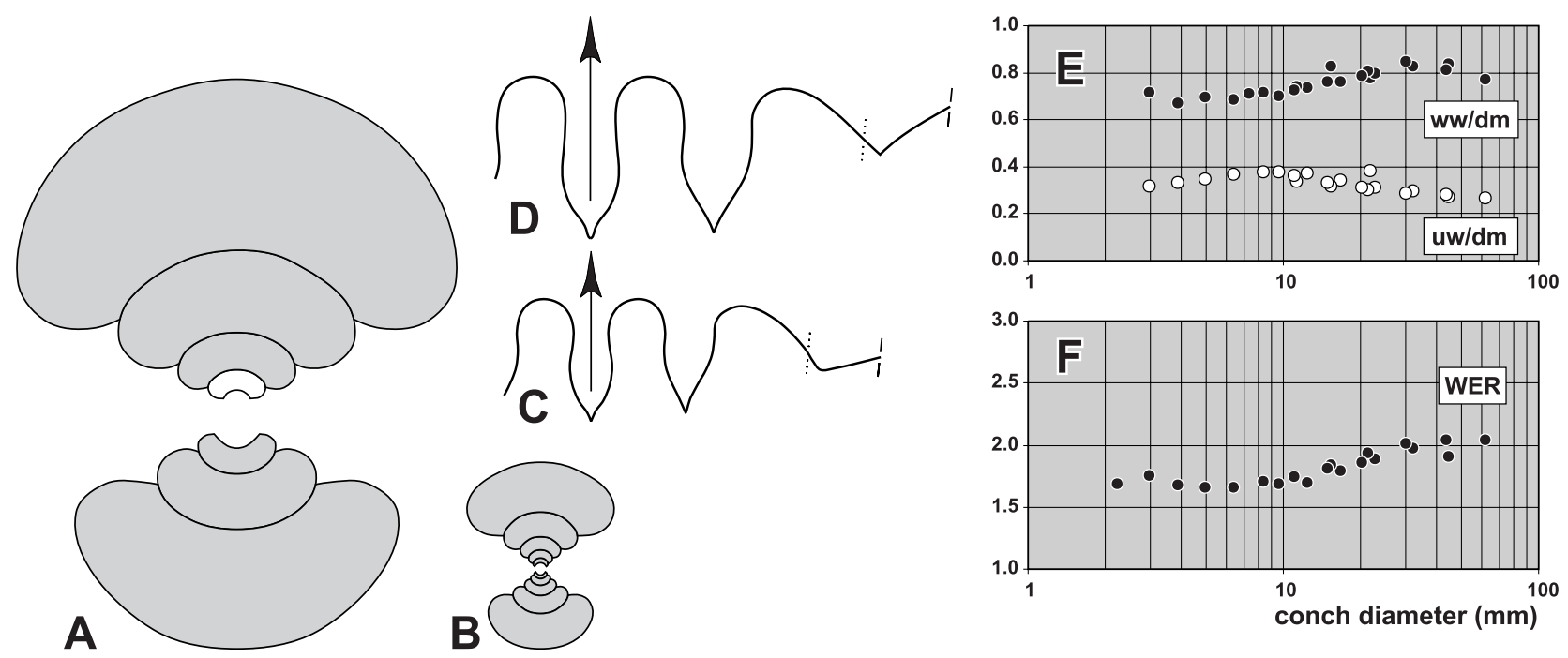

Fig. 38. Gattendorfia gisae n. sp. from bed 16 of the Aguelmous. A - Cross section, holotype MB.C.10176.1; $\times 1$. B - Cross section, paratype MB.C.10231.1; $\times 1$. C - Suture line, paratype MB.C.10211, at $20.9 \mathrm{~mm} \mathrm{dm}, 16.3 \mathrm{~mm}$ ww, $7.2 \mathrm{~mm}$ wh; $\times 2 . \mathbf{D}-$ Suture line, holotype MB.C.10176.1, at $47.8 \mathrm{~mm} \mathrm{dm}, 37.6 \mathrm{~mm}$ ww, $25.3 \mathrm{~mm}$ wh; $\times 1$. E. Ontogenetic development of the whorl width index (ww/dm) and umbilical width index (uw/dm). F - Ontogenetic development of the whorl expansion rate (WER).

as well as the suture line. Its diameter is almost $62 \mathrm{~mm}$ and is thickly pachyconic $(\mathrm{ww} / \mathrm{dm}=0.77)$ with a moderate umbilicus $(\mathrm{uw} / \mathrm{dm}=0.27)$. The specimen is somewhat corroded but it appears that there are no details of ornament visible, and constrictions are lacking. The suture line shows a narrow, lanceolate and slightly pouched external lobe and a narrowly rounded ventrolateral saddle. The lanceolate adventive lobe is wider than the external lobe; both lobes have the same depth (Fig. 38D).

Paratype MB.C.10231.2 with a $128 \mathrm{~mm}$ conch diameter is the largest specimen of the material from Aguelmous. At this diameter, the conch is still thinly pachyconic $(\mathrm{uw} / \mathrm{dm}=0.60)$ with a narrow umbilicus $(\mathrm{uw} / \mathrm{dm}=0.21)$. The corroded shell surface shows strongly rursiradiate growth lines.

Discussion. G. gisae n. sp. differs from the other pachyconic species of Gattendorfia in the absence of a truly serpenticonic juvenile stage and by the rounded umbilical margin. A further distinguishing character is the adult heightening of the aperture, leading to a whorl expansion rate of 2.00 .

\section{Gattendorfia sp.}

Fig. 31F

* 2002 Zadelsdorfia sp. Korn, Klug, Ebbighausen \& Bockwinkel: fig. $5 \mathrm{G}, \mathrm{H}$.

Material. Rich El Mbidia (bed 18): 10 specimens.

Re marks. Only insufficiently preserved specimens are available for study, and therefore, the material is described in open nomenclature. Specimens such as MB.C.10189 (50 $\mathrm{mm} \mathrm{dm})$ have a thickly discoidal to pachyconic conch with an umbilicus of approxi- mately one fifth of the conch diameter. They possess faint riblets, which extend almost linearly or convexly across the flanks and turn back to a wide and shallow ventral sinus. A faint spiral ornament is visible in some of the specimens. The suture line has a slightly pouched external lobe, slightly inflated ventrolateral saddle, and an asymmetric adventive lobe with steep ventral flank.

\section{Kazakhstania Librovitch, 1940}

Type species. Gattendorfia (Kazakhstania) karagandensis Librovitch, 1940.

\section{Kazakhstania evoluta (Vöhringer, 1960)}

Figs 39A, B, 40

* 1960 Gattendorfia evoluta Vöhringer: 159, fig. 34a-b, pl. 5: fig. $4 a-b$

2006 Kazakhstania evoluta. - Bockwinkel \& Ebbighausen: 112, figs $29,30 \mathrm{E}-\mathrm{H}$.

Material. Bou Tlidat (bed 2): 2 specimens, Bou Tlidat (bed 12): 2 specimens, Tizi Ibaouâne (bed 2): 3 specimens.

Remarks. The material from Aguelmous consists of small specimens which reach only $7 \mathrm{~mm}$ in conch diameter. A suture line is shown in Fig. 40; it shows a very deep, lanceolate external sinus and a U-shaped adventive lobe that is much shallower. This lateral lobe lies on the umbilical wall.

\section{Kazakhstania nitida Bockwinkel \& Ebbighausen, 2006}

Figs 39C, D, 41

* 2006 Kazakhstania nitida Bockwinkel \& Ebbighausen: 113, figs $30 \mathrm{~A}, \mathrm{~B}, 32$. 


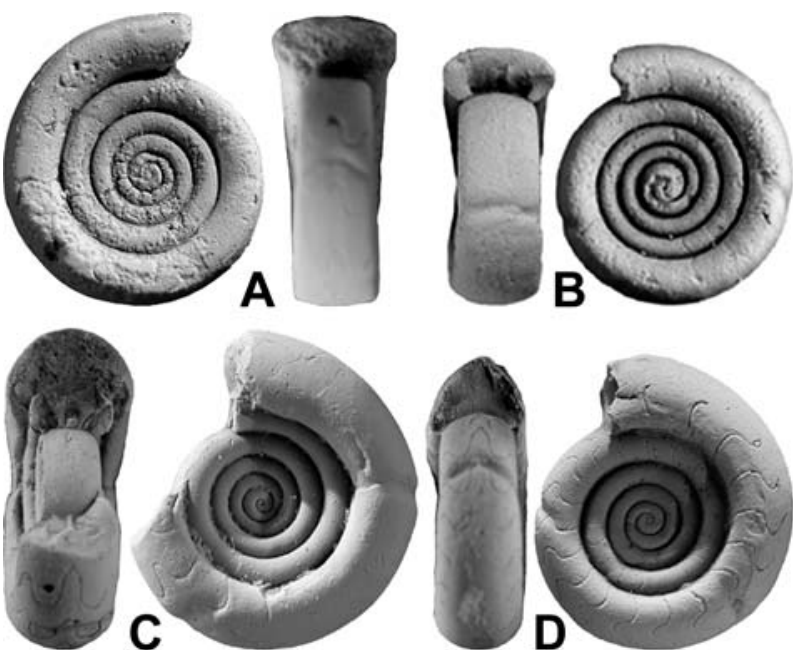

Fig. 39. Kazakhstania from Fezzou, all $\times 5$. A - Kazakhstania evoluta (Vöhringer, 1960), specimen MB.C.10163.1 from Bou Tlidat, bed 2, lateral and dorsal views. B - Kazakhstania evoluta (Vöhringer, 1960), specimen MB.C.10221.1 from Tizi Ibaouâne, bed 2, dorsal and lateral views. C - Kazakhstania nitida Bockwinkel \& Ebbighausen, 2006, specimen MB.C.10213 from Tazoult, dorsal and lateral views. D - Kazakhstania nitida Bockwinkel \& Ebbighausen, 2006, specimen MB.C.10164.1 from Bou Tlidat, bed 2, dorsal and lateral views.

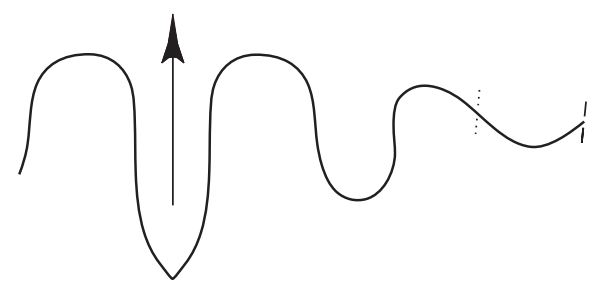

Fig. 40. Kazakhstania evoluta (Vöhringer, 1960) from bed 2 of the Aguelmous. Suture line, specimen MB.C.10163.1, at $5.3 \mathrm{~mm} \mathrm{dm}, 2.2 \mathrm{~mm}$ ww, $1.0 \mathrm{~mm}$ wh; $\times 20$.
Material. Bou Tlidat (bed 2): 11 specimens, Tazoult (bed 2): 2 specimens, Tazoult (loose): 1 specimen.

Remarks. The new material consists of specimens smaller than those of the suite from Mfis (Bockwinkel \& Ebbighausen 2006). They confirm the original description, and information on the juvenile suture can be added: the adventive lobe is rounded at $4.8 \mathrm{~mm}$ conch diameter and only half as deep as the external lobe, which has subparallel flanks.

Suborder Goniatitina Hyatt, 1884

Superfamily Pericycloidea Hyatt, 1900

Family Pericyclidae Hyatt, 1900

\section{Goniocyclus Gordon, 1986}

Type species. Goniatites blairi, Miller \& Gurley, 1896.

\section{Goniocyclus elatrous Korn, Klug, Ebbighausen \& Bockwinkel, 2002}

Figs 42A, B, 43
* 2002 Goniocyclus elatrous Korn, Klug, Ebbighausen \& Bockwinkel: 82, fig. 6A, B, C.

Material. Rich El Mbidia (bed 18): 9 specimens.

R e marks. Only fragmentarily preserved specimens are available, but these contribute additional information about the species. The new material consists of larger specimens than the original suite, but the specimens are very similar in conch form and ornament. In Particular specimens MB.C.10186.1 and MB.C.10186.2 possess sharp rursiradiate ribs and delicate spiral ornament in the rib interspaces. Specimen MB.C.10186.3 was sectioned but only allows the study of the last 2. whorls. The whorl outline is strongly affected by the sharp ribs (Fig. 43).
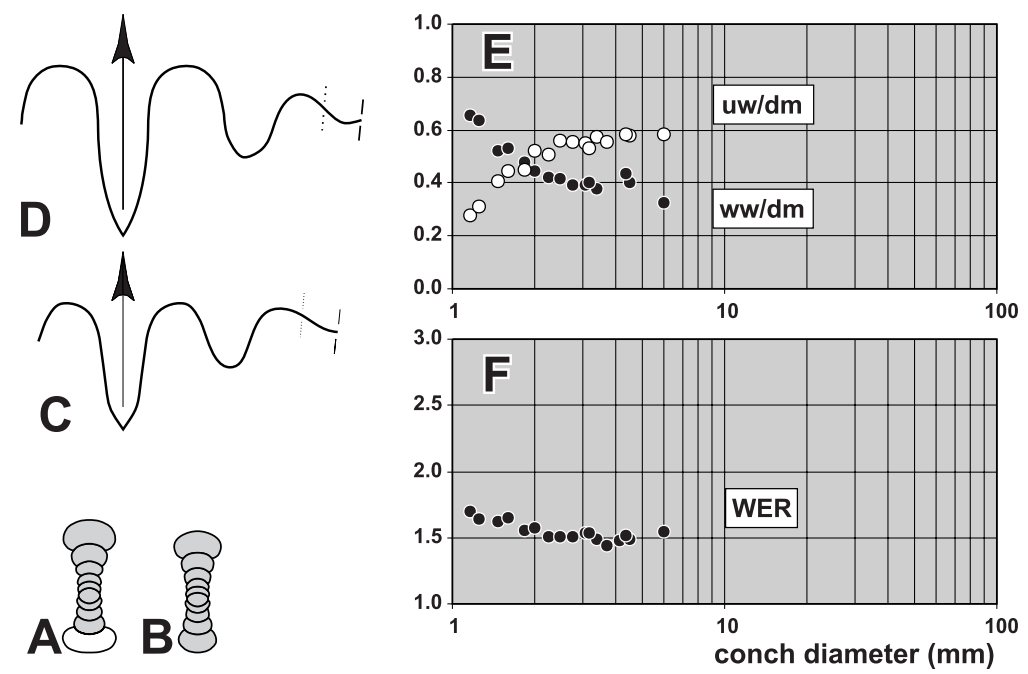

Fig. 41. Kazakhstania nitida Bockwinkel \& Ebbighausen, 2006 from bed 2 of the Aguelmous. A - Cross section, specimen MB.C.10164.2; $\times 3$. B - Cross section, specimen MB.C.10164.3; $\times 3$. C - Suture line, specimen MB.C.10164.3, at ca. $3.9 \mathrm{~mm} \mathrm{dm}$, $1.6 \mathrm{~mm}$ ww, $1.0 \mathrm{~mm}$ wh; $\times 15$. D - Suture line (reversed), specimen MB.C.10164.4, at $4.8 \mathrm{~mm} \mathrm{dm}, 1.6 \mathrm{~mm}$ ww, $1.1 \mathrm{~mm}$ wh; $\times 15$. E Ontogenetic development of the whorl width index $(\mathrm{ww} / \mathrm{dm})$ and umbilical width index (uw/dm). F - Ontogenetic development of the whorl expansion rate (WER). 


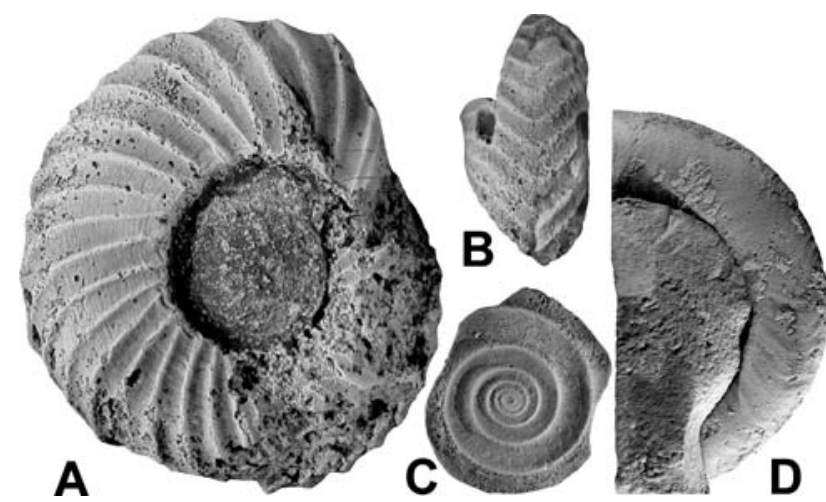

Fig. 42. Goniocyclus and Eocanites from Fezzou, all $\times 1$. A Goniocyclus elatrous Korn et al., 2002, specimen MB.C.10186.1 from Rich el Mbidia, bed 18, lateral view. B - Goniocyclus elatrous Korn et al., 2002, Specimen MB.C.10186.1 from Rich el Mbidia, bed 18, ventral view. C - Eocanites sp., specimen MB.C.10183.1, from Rich el Mbidia, bed 18, lateral view. D Eocanites sp., specimen MB.C.10183.2, from Rich el Mbidia, bed 18 , lateral view.

Order Prolecanitida Miller \& Furnish, 1954

Superfamily Prolecanitoidea Hyatt, 1884

Family Prolecanitidae Hyatt, 1884

Subfamily Prolecanitinae Hyatt, 1884

\section{Eocanites Librovitch, 1957}

Type species. Protocanites supradevonicus (Schindewolf, 1926).

\section{Eocanites simplex Bockwinkel \& Ebbighausen, 2006}

Figs 44A, 45

* 2006 Eocanites simplex Bockwinkel \& Ebbighausen: 120, figs 37, 38I-K.

Material. Bou Tlidat (bed 2): 10 specimens, Tazoult (bed 2): 3 specimens, Tizi Ibaouâne (bed 2): 1 specimen.

Description. The new material permits the description of conch ontogeny, which, however, is rather unspectacular. The conch, beginning pachyconic in the initial stage, becomes rapidly thinner and has a ww/dm ratio of 0.40 at $4 \mathrm{~mm}$ diameter. At
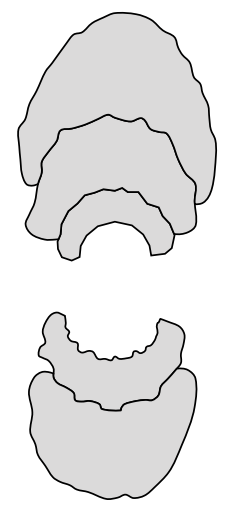

Fig. 43. Goniocyclus elatrous Korn et al., 2002, cross section of specimen MB.C.10286.3 from Rich el Mbidia, bed $18, \times 3$. the same time, the umbilicus is opened to a uw/dm ratio of 0.50 . The whorl expansion rate is stable throughout ontogeny, being 1.75-1.80 (Fig. 45D, E).

Specimen MB.C.10160.1 is the best preserved of the newly collected material (Fig. 44A). It has $13 \mathrm{~mm}$ diameter and is fully chambered with 13 septa on the last volution. The whorl cross section is almost circular, and the rate at which the whorls embrace is low. Faint riblets are visible on outer flanks and venter, they form a shallow ventral sinus. The suture line of the specimen possesses an external lobe that is much deeper than the asymmetric adventive lobe. Both are separated by an inflated ventrolateral saddle.

\section{Eocanites sp.}

Fig. 42C, D
* 2002 Eocanites sp. Korn, Klug, Ebbighausen \& Bockwinkel: fig. $5 \mathrm{E}, \mathrm{F}, \mathrm{K}$.

Material. Rich El Mbidia (bed 18): 2 specimens.

Remarks. The material is too poor for a distinct interpretation. The assignment to Eocanites is based on a close similarity to specimens figured by Korn et al. (2002), which show the characteristic suture line.

\section{Becanites Korn, 1997}

Type species. Protocanites algarbiensis Pruvost, 1914.

\section{Becanites sp. \\ Figs 44B, 46}

Material. Rich El Mbidia (bed 16): 1 specimen.

Re marks. The single specimen MB.C.10174 allows the attribution to a distinct genus, but nothing further. The conch is at $12.5 \mathrm{~mm}$ diameter, discoidal $(\mathrm{ww} / \mathrm{dm}=0.30)$ and widely umbilicate $(\mathrm{uw} / \mathrm{dm}=$ 0.43 ). The whorls embrace only to a very low degree, and the whorl cross section is compressed and oval. In the penultimate whorl, there are some faint ribs visible, which turn back on the flanks. The suture line of the specimen possesses a lanceolate external lobe, a pouched and blunt adventive lobe, and a small lateral lobe that is similar to the adventive lobe.

\section{Kahlacanites Ebbighausen, Bockwinkel, Korn \& Weyer, 2004}

Type species. Kahlacanites mariae Ebbighausen, Bockwinkel, Korn \& Weyer, 2004 

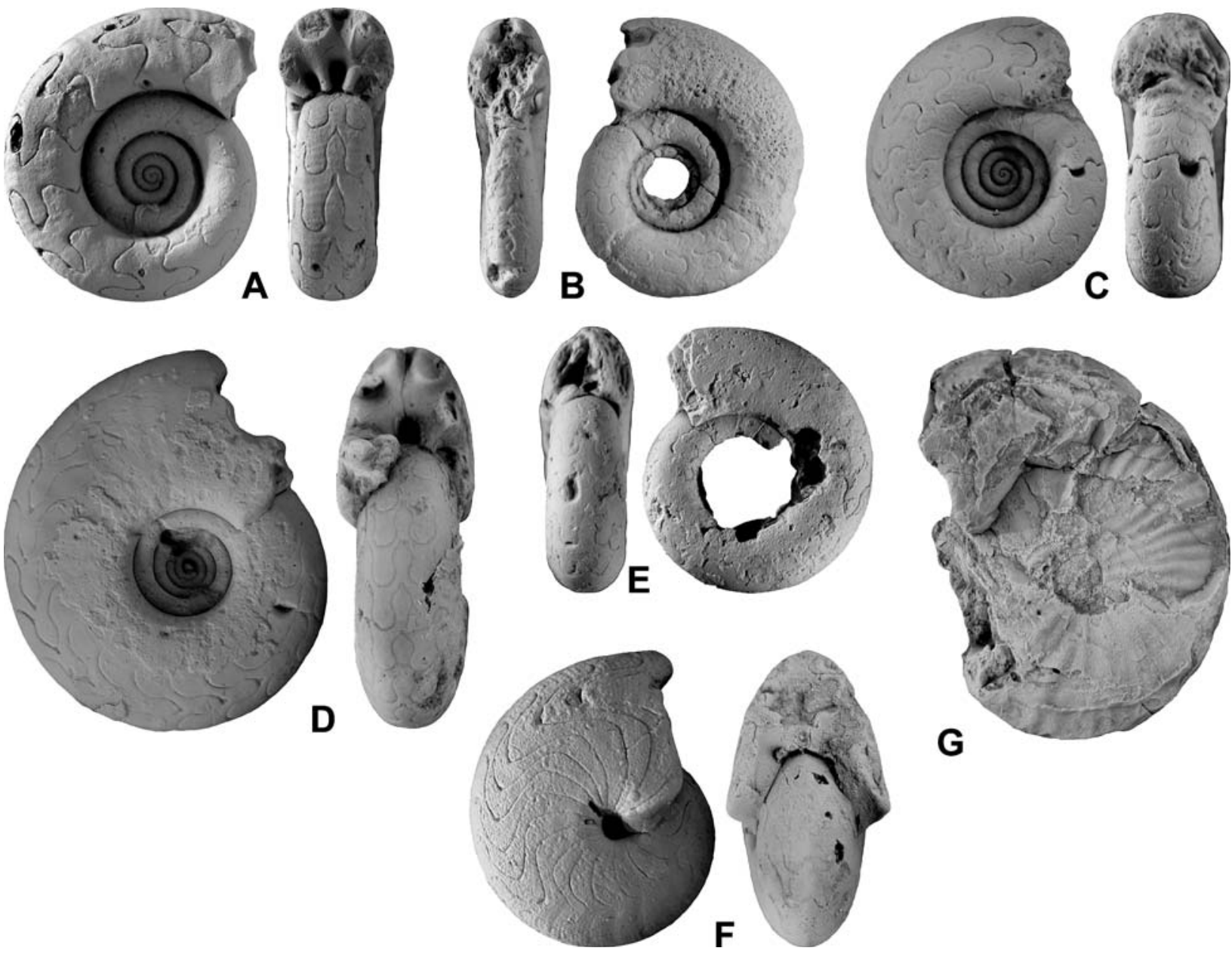

G

Fig. 44. Eocanites, Becanites, Kahlacanites, and gen. indet. from Fezzou. A - Eocanites simplex Bockwinkel \& Ebbighausen, 2006, specimen MB.C.10160.1 from Bou Tlidat, bed 2, lateral and dorsal views, ×3. B - Becanites sp., specimen MB.C.10174 from Rich el Mbidia, bed 16, dorsal and lateral views, $\times 2.5$. C - Kahlacanites mariae Ebbighausen et al. 2004, specimen MB.C.10236.1 from Tizi Ibaouâne, bed 16, lateral and dorsal views, $\times 2.5$. D - Kahlacanites mariae Ebbighausen et al. 2004, specimen MB.C.10181.1 from Tizi Ibaouâne, bed 16, dorsal and lateral views, $\times 2.5$. E - Kahlacanites meyendorffi Ebbighausen et al., 2004, specimen MB.C.10237 from Tizi Ibaouâne, bed 16, dorsal and lateral views, $\times 2.5$. F - gen. indet. 1 sp. indet, specimen MB.C.10226 from Tizi Ibaouâne, bed 12, lateral and dorsal views, $\times 5$. G - gen. indet. 2 sp. indet, specimen MB.C.10178 from Rich el Mbidia, bed 16, $\times 1$.
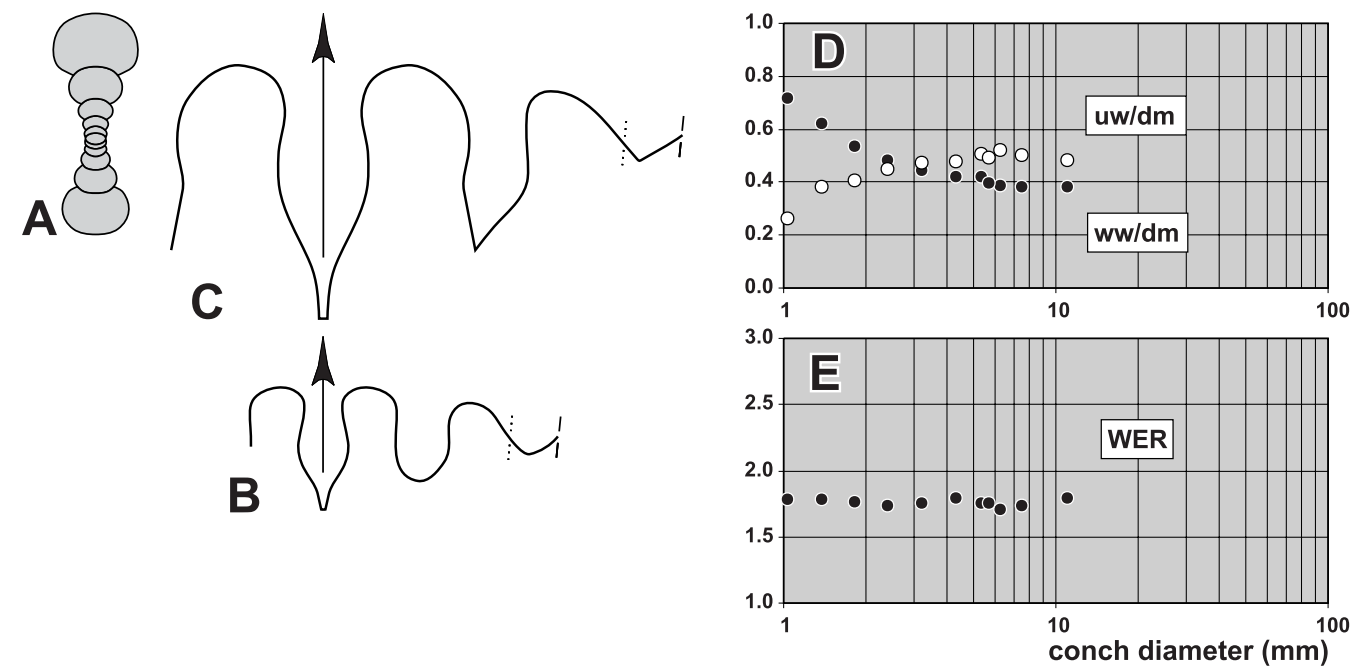

Fig. 45. Eocanites simplex Bockwinkel \& Ebbighausen, 2006 from bed 2 of the Aguelmous. A - Cross section, specimen MB.C.10160.2; $\times 3$. B - Suture line, specimen MB.C.10160.3, at $1.9 \mathrm{~mm}$ ww, $1.2 \mathrm{~mm}$ wh; $\times 14$. C - Suture line, specimen MB.C.10160.1, at $10.9 \mathrm{~mm} \mathrm{dm}, 4.1 \mathrm{~mm} \mathrm{ww}, 3.2 \mathrm{~mm}$ wh; $\times 8$. D - Ontogenetic development of the whorl width index (ww/dm) and umbilical width index (uw/dm). E - Ontogenetic development of the whorl expansion rate (WER). 


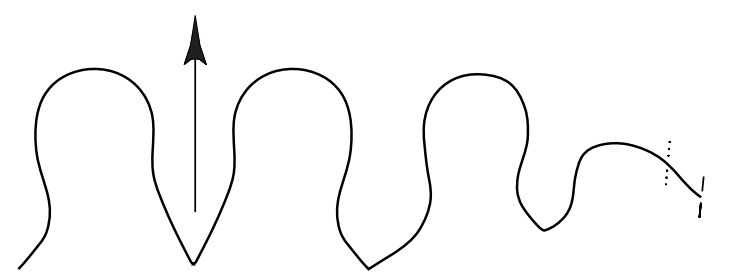

Fig. 46. Becanites sp., suture line, specimen MB.C.10174, at $10.3 \mathrm{~mm}$ dm, $3.4 \mathrm{~mm}$ ww, $3.4 \mathrm{~mm}$ wh; $\times 3$.

\section{Kahlacanites mariae Ebbighausen, Bockwinkel, Korn \& Weyer, 2004}

Figs $44 \mathrm{C}, \mathrm{D}, 47 \mathrm{~A}-\mathrm{F}$

* 2004 Kahlacanites mariae Ebbighausen, Bockwinkel, Korn \& Weyer: 147, figs 15C-E, 17A.

Material. Rich El Mbidia (bed 16): 3 specimens, Tizi Ibaouâne (bed 16): 49 specimens.

Description. The specimens from Aguelmous are much better preserved than the original material from the Gara el Kahla, and thus the description of the species can be updated (Fig. 47A, B). Cross sections MB.C.10236.2 and MB.C.10236.3 show the ontogenetic development of conch geometry, which in turn shows the transformation of ventrally depressed, semilunate innermost whorls to laterally compressed whorls in the adult stage. The ww/dm ratio decreases from 0.60 to 0.30 between 1.5 and $20 \mathrm{~mm}$ conch diameter, but the uw/dm ratio remains rather stable around 0.40. A slight opening of the umbilicus (uw/dm $=0.40-0.50)$ can be seen between 2 and $5 \mathrm{~mm}$ dm (Fig. 47E, F).

The suture lines of specimens MB.C.10218 and MB.C.10181.1 have a pouched external lobe which is widest near its base. On the flank an almost symmetric, inflated ventrolateral saddle, a lanceolate adventive lobe, an inflated dorsolateral saddle, and a lateral lobe follows. A shallow umbilical lobe lies on the umbilical wall (Fig. 47C, D). The two figured suture lines differ in the width of their elements: the ventrolateral saddle is wider in the larger specimen, and the adventive lobe is narrower. By contrast, the lateral lobe is wider in the larger specimen.

Specimen MB.C.10181.1 is the best preserved within the material. It has $20 \mathrm{~mm}$ diameter and is fully septate with 18 chambers on the last volution. The steinkern is smooth except for a barely visible radial folding on the surface. Specimen MB.C.10236.5 $(19 \mathrm{~mm} \mathrm{dm})$ is preserved with attached shell remains. These show rather coarse growth lines, extending with a lateral sinus and a ventrolateral projection across the flanks.

\section{Kahlacanites meyendorffi Ebbighausen, Bockwinkel, Korn \& Weyer, 2004 \\ Figs 44E, 47G}

*2004 Kahlacanites meyendorffi Ebbighausen, Bockwinkel, Korn \& Weyer: 147, fig. 15A, B.

Material. Tizi Ibaouâne (bed 16): 1 specimen.

Remarks. Only one specimen (MB.C.10237; $14 \mathrm{~mm} \mathrm{dm}$ ) is available; it confirms the original Description. The conch is discoidal $(\mathrm{ww} / \mathrm{dm}=0.37)$ with a wide umbilicus $(\mathrm{uw} / \mathrm{dm}=44)$, and the whorl cross section is oval with slightly converging flanks. The suture line is characteristic for the genus with a pouched external lobe, a similarly shaped adventive lobe, a smaller lateral lobe, and a very shallow umbilical lobe on the umbilical wall (Fig. 47G).
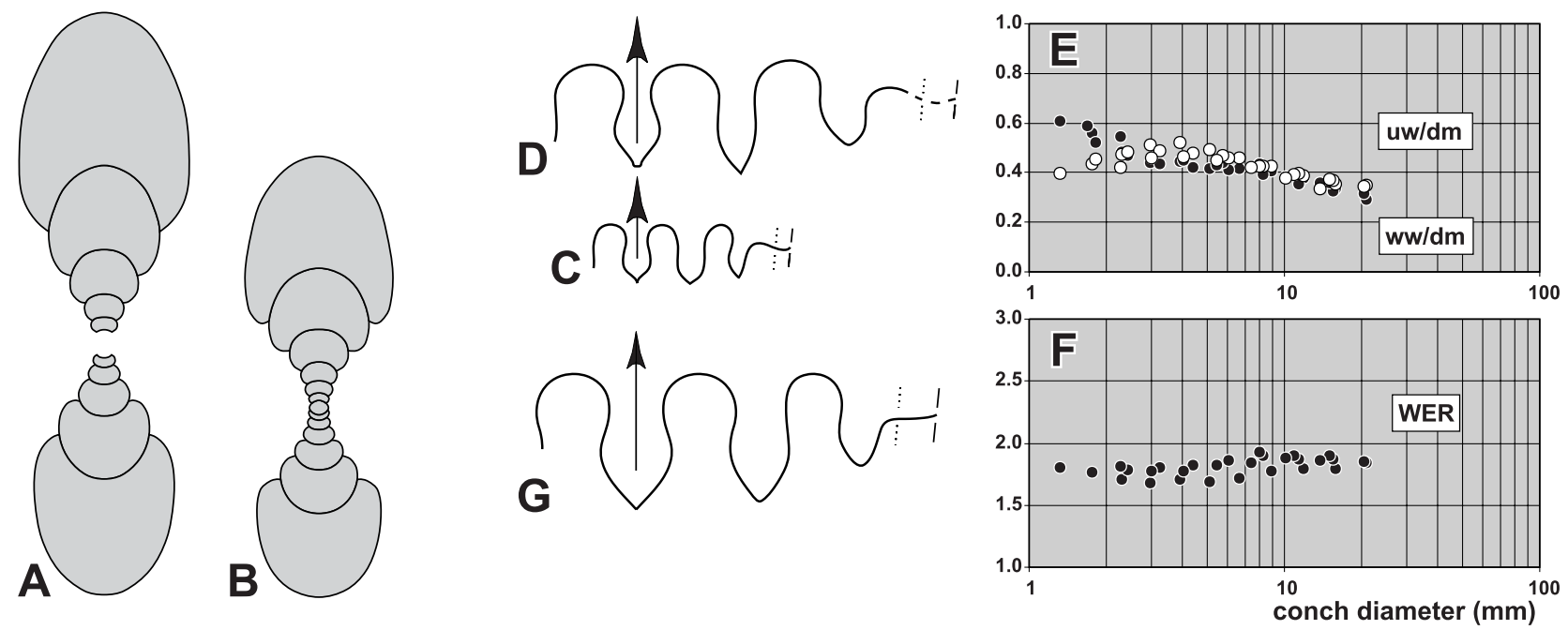

Fig. 47. Kahlacanites mariae Ebbighausen et al., 2004 (A-F) and Kahlacanites meyendorffi Ebbighausen et al., 2004 (G) from bed 16 of the Aguelmous. A - Cross section, specimen MB.C.10236.2; ×3. B - Cross section, specimen MB.C.10236.3; $\times 3$. C Suture line, specimen MB.C.10218, at ca. $10.2 \mathrm{~mm} \mathrm{dm}$, ca. $3.7 \mathrm{~mm} \mathrm{ww}, 3.4 \mathrm{~mm}$ wh; $\times 10$. D - Suture line, specimen MB.C.10181.1, at $19.3 \mathrm{~mm} \mathrm{dm}, 6.8 \mathrm{~mm}$ ww, $8.4 \mathrm{~mm}$ wh; $\times 10 . \mathbf{E}-$ Ontogenetic development of the whorl width index (ww/dm) and umbilical width index $(\mathrm{uw} / \mathrm{dm})$. F - Ontogenetic development of the whorl expansion rate (WER). G - Suture line, specimen MB.C.10237, at $3.6 \mathrm{~mm}$ ww, $3.1 \mathrm{~mm}$ wh; $\times 10$. 


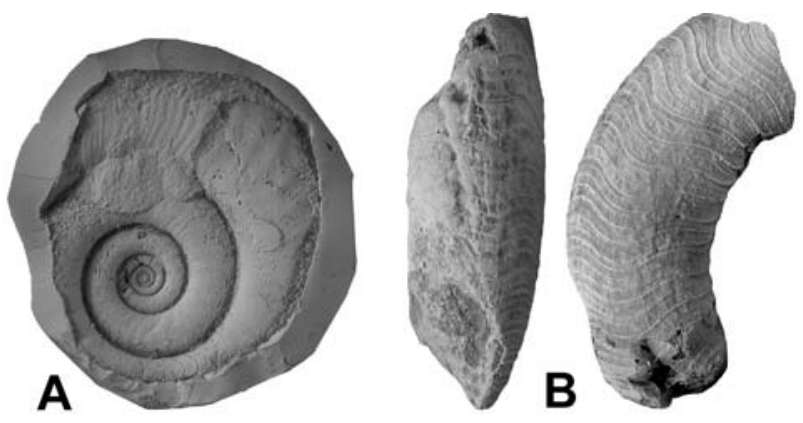

Fig. 48. Protocanites hollardi Korn et al., 2002 from Rich el Mbidia, bed 18. A - Specimen MB.C.10188.2, lateral view, $\times 1$. B - Specimen MB.C.10188.1, dorsal and lateral views, $\times 2$.

Subfamily Protocanitinae Weyer, 1972

\section{Protocanites Schmidt, 1922}

Type species. Goniatites lyoni Meek \& Worthen, 1860.

\section{Protocanites hollardi Korn, Klug, Ebbighausen \& Bockwinkel, 2002}

Figs 48, 49

* 2002 Protocanites hollardi Korn, Klug, Ebbighausen \& Bockwinkel: 82, fig. 5A-C.

Material. Rich El Mbidia (bed 18): 64 specimens.

Remarks. Only poor material is available. The two specimens MB.C.10188.2 and MB.C.10188.3 preserve parts of the suture line (Fig. 49B), which permits an assignment to the genus Protocanites, and MB.C.10188.2 possesses a radial ornament consisting of fine but rhythmically strengthened growth lines. These extend in rectiradiate direction across the flanks.

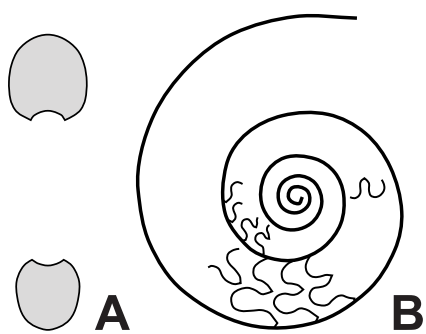

Fig. 49. Protocanites hollardi Korn et al., 2002 from bed 18 of the Aguelmous. A - Cross section, specimen MB.C.10188.3; $\times 1$. B - Side view of a cast with suture lines, specimen MB.C.10188.2; $\times 2$.

gen. indet. 1

gen. indet. 1 sp. indet.

Figs 44F, 50

Material. Tizi Ibaouâne (bed 12): 1 specimen.

Description. The single specimen MB.C.10226 with $8 \mathrm{~mm}$ diameter is fully septate with approximately 16 chambers (Fig. 44F). It is a lenticular

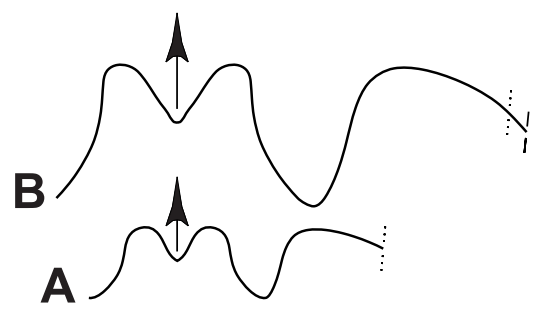

Fig. 50. gen. indet. $1 \mathrm{sp}$. indet., suture lines of specimen MB.C.10226 from Tizi Ibaouâne, bed 12, ×7. A - At $2.6 \mathrm{~mm}$ ww, $2.2 \mathrm{~mm}$ wh. $\mathbf{B}$ - At $7.9 \mathrm{~mm} \mathrm{dm}, 3.9 \mathrm{~mm}$ ww, $4.4 \mathrm{~mm}$ wh.

conch $(\mathrm{ww} / \mathrm{dm}=0.55)$ with an almost closed umbilicus and a keeled narrow venter. The aperture is high $(\mathrm{WER}=2.28)$. Apart from the conch shape, the specimen is particularly peculiar because of its suture line, which is so far notknown from any other ammonoid. It may be a juvenile suture, in which some distinctive characters are not yet developed, but the very small, broadly $\mathrm{V}$-shaped external lobe and the very large, asymmetric and rounded adventive lobe are very striking (Fig. 50).

gen. indet. 2

gen. indet. 2 sp. indet.

Fig. 44G

Material. Rich El Mbidia (bed 16): 1 specimen.

Remarks. The single specimen MB.C.10178 with $54 \mathrm{~mm}$ diameter is fragmentary, and unfortunately, many aspects of conch and septum morphology are unknown. It is obvious that the conch is thinly discoidal, but caused by erosion, it cannot be stated whether the venter is rounded, tabular, or acute. The conch is ornamented with shallow sinuous ribs, some of them intercalated in the midflank area. In its general appearance, the specimen resembles the genus Qiannanites Ruan, 1981, but more material is required for an assignment to this genus.

\section{Acknowledgements}

We thank Dieter Weyer (Berlin) for his support during measurement and interpretation of the section and for making his material available. We are particularly indebted to Dieter Korn (Berlin) for discussions and his patient support in all stages of writing the article. Lhcen Mahraz (Fezzou) contributed much in the field and collected some of the material. Evelin Stenzel (Berlin) did the careful preparation of some specimens. We acknowledge the reviews of Christian Klug (Zürich) and John Malinky (Escondido, CA). The authors express their thanks to Ralf Thomas Becker (Münster) for critically reading the manuscript.

\section{References}

Bartzsch, K. \& Weyer, D. 1987. Das unterkarbonische Ammonoidea-Tribus Pseudarietini. - Abhandlungen und Berichte für Naturkunde und Vorgeschichte 13: 59-68.

Becker, R. T., House, M. R., Bockwinkel, J., Ebbighausen, V. \& Aboussalam, S. 2002. Famennian ammonoid zones of 
the eastern Anti-Atlas (southern Morocco). - Münstersche Forschungen zur Geologie und Paläontologie 93: 159205.

Bockwinkel, J. \& Ebbighausen V. 2006. A new ammonoid fauna from the Gattendorfia-Eocanites Genozone of the Anti-Atlas (Early Carboniferous, Morocco). - Fossil Record 9 (1): 87-129.

Clariond, L. 1935. Etude stratigraphique sur les terrains du sud marocain : La série Primaire du Sarro, du Maïder et du Tafilalet. - Association pour l'étude géologique de la Méditerranée occidentale 5: 3-10.

Destombes, J. \& Hollard, H. 1988. Todrha - Ma'der, échelle 1:200,000. - In Fetah, S. E. M., Bensaïd, M. M. \& Dahmani, M. M. (eds): Carte Géologique du Maroc. - Notes et Mémoires du Service Géologique du Maroc, 243; Rabat.

Ebbighausen, V., Bockwinkel, J., Korn, D. \& Weyer, D. 2004. Early Tournaisian ammonoids from Timimoun (Gourara, Algeria). - Mitteilungen aus dem Museum für Naturkunde in Berlin, Geowissenschaftliche Reihe 7: 133-152.

Ebbighausen, V. \& Korn, D. 2007. Conch geometry and ontogenetic trajectories in the Late Devonian triangularly coiled ammonoid Wocklumeria. - Neues Jahrbuch für Geologie und Paläontologie.

Gordon, M. jr. 1986. Late Kinderhookian (Early Mississippian) Ammonoids of the Western United States. - Journal of Paleontology, Memoir 19: 1-36.

Hall, J. 1860. Notes and observations upon fossils of the Goniatite Limestone in the Marcellus shale of the Hamilton group, in the eastern and central parts of the State of New York, and those of the Goniatite beds of Rockford, Indiana; with some analogous forms from the Hamilton group proper. - Annual Reports of the Regents of the University of the State New York, on the condition of the State Cabinet of Natural History, and the Historical and Antiquarian Collection annexed thereto 13: 59-112.

Hollard, H. 1958. Découverte des Goniatites tournaisiennes dans le Maider (Province du Tafilalet, Maroc). - Comptes Rendus Hebdomadaires des Séances de l'Académie des Sciences 247: 789-792.

Hyatt, A. 1883-1884. Genera of the fossil cephalopods. Proceedings of the Boston Society of Natural History 22: 253-338 (253-272 publ. 1883, 237-238 publ. 1884).

- 1900. Tetrabranchiate Cephalopoda. - In Zittel-Eastman: Text-book of palaeontology, 1st edition: 502-604, London.

Ji Qiang 1985. Study on the Phylogeny, Taxonomy, Zonation and Biofacies of Siphonodella (Conodonta). - Bulletin of the Institute of Geology, Chinese Academy of Geological Sciences 11: 51-75.

Kaiser, S. I. 2005. Mass extinction, climatic and oceanographic changes at the Devonian/Carboniferous boundery. - Dissertation zur Erlangung des akademischen Grades eines Doktors der Naturwissenschaften an der Fakultät für Geowissenschaften der Ruhr-Universität Bochum (Germany), 156 pp; Bochum. (unpublished)

Korn, D. 1984. Die Goniatiten der Stockumer ImitocerasKalklinsen (Ammonoidea; Devon/Karbon-Grenze). Courier Forschungsinstitut Senckenberg 67: 71-89.

- 1992a. Heterochrony in the evolution of Late Devonian Ammonoids. - Acta Palaeontologica Polonica 37 (1): 21-36.

- 1992b. Ammonoideen aus dem Devon/Karbon-Grenzprofil an der Grünen Schneid (Karnische Alpen, Österreich). - Jahrbuch der Geologischen Bundesanstalt 135: 7-19.

- 1994. Oberdevonische und unterkarbonische Prionoceraten aus dem Rheinischen Schiefergebirge. - Geologie und Paläontologie in Westfalen 30: 1-85.

- 1997. The Palaeozoic ammonoids of the South Portuguese Zone. - Memórias do Instituto Geológico e Mineiro de Portugal 33: 1-132.

- 1999. Famennian Ammonoid Stratigraphy of the Ma'der and Tafilalt (Eastern Anti-Atlas, Morocco). - Abhandlungen der Geologischen Bundesanstalt 54: 147-179.
Korn, D., Bockwinkel, J. \& Ebbighausen, V. 2007. Tournaisian and Viséan ammonoid stratigraphy in North Africa. Neues Jahrbuch für Geologie und Paläontologie 242: 127-148

Korn, D., Ebbighausen, V., Bockwinkel, J. \& Klug, C. 2003. The A-mode sutural ontogeny in prolecanitid ammonoids. Palaeontology 46 (6): 1123-1132.

Korn, D. \& Feist, R. (2007): Early Carboniferous ammonoid faunas and stratigraphy of the Montagne Noire (France). Fossil Record 10 (2): 99-124

Korn, D. \& Klug, C. 2002. Ammoneae Devonicae. In: W. Riegraf (Ed.), Fossilium Catalogus, Animalia I, 138: xviii + 375 pp., Backhuys, Leiden.

Korn, D., Klug, C., Ebbighausen, V. \& Bockwinkel, J. 2002. Palaeogeographical meaning of a Middle Tournaisian ammonoid fauna from Morocco. - Geologica et Palaeontologica 36: 79-86.

Korn, D. \& Kullmann, J. 1996. GONIAT-Paleozoic Ammonoid Database System, Version 2.60. - Geologisch-Paläotologisches Institut, Tübingen.

Korn, D. \& Weyer, D. 2003. High resolution stratigraphy of the Devonian-Carboniferous transitional beds in the Rhenish Mountains. - Mitteilungen aus dem Museum für Naturkunde in Berlin, Geowissenschaftliche Reihe 6: 79- 124.

Korn, D. \& Vöhringer, E. 2004. Allometric growth and intraspecific variability in the basal Carboniferous ammonoid Gattendorfia crassa Schmidt, 1924. - Paläontologische Zeitschrift 78 (2): 419-426.

Librovitch, L. S. 1957. O nekotorykh novykh gruppakh goniatitov iz kamennougolnykh otlozheniy SSSR. - Ezhegodnik Vsesoyuznogo Paleontologicheskogo Obshchestva 16: 246-272.

Meek, F. B. \& Worthen A. H. 1860. Descriptions of new Carboniferous fossils from Illinois and other western States. - Proceedings of the Acadademy of Natural Science Philadelphia 1860: 471.

Miller, A. K. \& Furnish, W. M. 1954. The classification of the Paleozoic ammonoids. - Journal of Paleontology 28: 685-692.

Miller, S. A. \& Gurley, W. F. E. 1896. New species of Palaeozoic invertebrates from Illinois and other states. - Bulletin of the Illinois State Museum of Natural History 11: 1-50.

Münster, G. Graf zu 1832. Über die Planuliten und Goniatiten im Uebergangs-Kalk des Fichtelgebirges. - 38 pp, Birner, Bayreuth

Petter, G. 1959. Goniatites Dévoniennes du Sahara. - Publications du Service de la Carte Géologique de l'Algérie, Nouvelle Série, Paléontologie 2: 1-313.

- 1960 Clymènies du Sahara. - Publications du Service de la Carte Géologique de l'Algérie, Nouvelle Série, Paléontologie 6: $1-58$.

Pruvost, P. 1914. Observations sur les terrains Dévoniens et Carbonifères du Portugal et leur faune. - Comunicações da Commissão do Serviço Geológico de Portugal 10 (1): 1-21.

Ruan, Yi-ping 1981. Devonian and earliest Carboniferous ammonoids from Guangxi and Guizhou. - Memoirs of Nanjing Institute of Geology and Palaeontology, Academia Sinica 15: 1-152.

Ruzhencev, V. E. 1950. Verkhnekamennougol'nye ammonity Urala. - Trudy Paleontologicheskogo Instituta Akademiya Nauk SSSR 29: 1-223.

Sandberg, C. A., Ziegler, W., Leuteritz, K. \& Brill, S. M. 1978. Phylogeny, speciation, and zonation of Siphonodella (Conodonta, Upper Devonian and Lower Carboniferous). - Newsletters on Stratigraphy 7 (2): 102-120.

Schindewolf, O. H. 1920. Neue Beiträge zur Kenntnis der Stratigraphie und Paläontologie des deutschen Oberdevons. - Senckenbergiana 2 (3/4): 114-129.

- 1923. Beiträge zur Kenntnis des Paläozoikums in Oberfranken, Ostthüringen und dem Sächsischen Vogtlande. I. Stratigraphie und Ammoneenfauna des Oberdevons von Hof a. S. - Neues Jahrbuch für Mineralogie, Geologie und Paläontologie, Beilageband 49: 250-357, 393-509. 
- 1926. Zur Kenntnis der Devon-Karbon-Grenze in Deutschland. - Zeitschrift der Deutschen Geologischen Gesellschaft 78: $88-133$.

Schmidt, H. 1922. Das Oberdevon-Culm-Gebiet von Warstein i. W. und Belecke. - Jahrbuch der Preußischen Geologischen Landesanstalt 41 (for 1920): 254-339.

- 1925. Die carbonischen Goniatiten Deutschlands. - Jahrbuch der Preußischen Geologischen Landesanstalt 45 (for 1924): 489-609.

Vöhringer, E. 1960. Die Goniatiten der unterkarbonischen Gattendorfia-Stufe im Hönnetal (Sauerland). - Fort- schritte in der Geologie von Rheinland und Westfalen 3 (1): 107-196.

Wedekind, R. 1918. Die Genera der Palaeoammonoidea (Goniatiten). Mit Ausschluß der Mimoceratidae, Glyphioceratidae und Prokecanitidae. - Palaeontographica 62: 85-184.

Weyer, D. 1972. Zum Alter der Ammonoideen-Fauna des Marshall-Sandsteins (Unterkarbon; Michigan, USA). Berichte der deutschen Gesellschaft für geologische Wissenschaften, A, Geologie, Paläontologie 17 (3): 325-350.

\section{Appendix}

Conch dimensions and ratios of ammonoids from the Aguelmous.

\begin{tabular}{|c|c|c|c|c|c|c|c|c|c|c|}
\hline & $\mathrm{dm}$ & ww & wh & uw & ah & $\mathrm{ww} / \mathrm{dm}$ & ww/wh & $\mathrm{uw} / \mathrm{dm}$ & WER & IZR \\
\hline \multicolumn{11}{|c|}{ Globimitoceras rharrhizense n. sp. } \\
\hline \multirow[t]{2}{*}{ MB.C.10185.6 } & 24.57 & 19.38 & 11.66 & 2.98 & 4.00 & 0.79 & 1.66 & 0.12 & 1.43 & 0.66 \\
\hline & 17.44 & 14.89 & 7.99 & 2.17 & 2.78 & 0.85 & 1.86 & 0.12 & 1.42 & 0.65 \\
\hline \multirow[t]{7}{*}{ MB.C.10185.3 } & 23.80 & 16.61 & 11.41 & 2.48 & 4.04 & 0.70 & 1.46 & 0.10 & 1.45 & 0.65 \\
\hline & 16.36 & 12.35 & 7.87 & 1.62 & 3.06 & 0.75 & 1.57 & 0.10 & 1.51 & 0.61 \\
\hline & 10.56 & 9.75 & 5.22 & 1.13 & 2.05 & 0.92 & 1.87 & 0.11 & 1.54 & 0.61 \\
\hline & 6.89 & 7.13 & 3.44 & 0.72 & 1.21 & 1.03 & 2.07 & 0.10 & 1.47 & 0.65 \\
\hline & 4.72 & 5.19 & 2.31 & 0.64 & 0.73 & 1.10 & 2.25 & 0.14 & 1.40 & 0.68 \\
\hline & 3.35 & 3.91 & 1.61 & 0.56 & 0.58 & 1.17 & 2.43 & 0.17 & 1.46 & 0.64 \\
\hline & 2.29 & 3.12 & 1.09 & 0.39 & 0.50 & 1.36 & 2.86 & 0.17 & 1.64 & 0.54 \\
\hline
\end{tabular}

Acutimitoceras hollardi Bockwinkel \& Ebbighausen, 2006

$\begin{array}{lrlllllllll}\text { MB.C.10154.4 } & 13.98 & 8.18 & 7.42 & 1.08 & 4.52 & 0.59 & 1.10 & 0.08 & 2.18 & 0.39 \\ \text { MB.C.10154.1 } & 8.96 & 5.34 & 4.99 & 0.79 & 2.45 & 0.60 & 1.07 & 0.09 & 1.90 & 0.51 \\ & 4.77 & 3.42 & 2.35 & 0.84 & 1.24 & 0.72 & 1.45 & 0.18 & 1.82 & 0.47 \\ \text { MB.C.10192.4 } & 10.22 & 6.01 & 5.84 & 0.47 & 3.07 & 0.59 & 1.03 & 0.05 & 2.04 & 0.47 \\ & 5.16 & 3.50 & 2.62 & 0.66 & 1.32 & 0.68 & 1.34 & 0.13 & 1.80 & 0.50 \\ & 2.86 & 2.14 & 1.27 & 0.69 & 0.68 & 0.75 & 1.69 & 0.24 & 1.72 & 0.46 \\ & 1.68 & 1.22 & 0.65 & 0.54 & 0.39 & 0.73 & 1.87 & 0.32 & 1.71 & 0.40 \\ & 0.94 & 0.90 & 0.50 & 0.06 & 0.25 & 0.96 & 1.79 & 0.07 & 1.84 & 0.51\end{array}$

Acutimitoceras occidentale Bockwinkel \& Ebbighausen, 2006

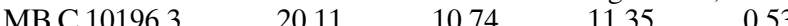

$\begin{array}{rrrrr}\text { MB.C.10196.3 } & 20.11 & 10.74 & 1.35 & 0.53 \\ & 10.84 & 6.45 & 5.88 & 0.68 \\ & 5.99 & 3.78 & 2.90 & 0.96 \\ & 3.53 & 2.40 & 1.53 & 0.93 \\ & 2.16 & 1.44 & 0.85 & 0.69 \\ \text { MB.C.10196.4 } & 1.36 & 1.09 & 0.58 & 0.35 \\ & 14.79 & 7.85 & 8.38 & 0.48 \\ & 7.81 & 4.65 & 4.08 & 0.83 \\ & 4.27 & 2.84 & 1.83 & 1.14 \\ & 2.56 & 1.73 & 1.03 & 0.81 \\ & 1.60 & 1.28 & 0.71 & 0.41 \\ & 0.98 & 0.94 & 0.54 & 0.06\end{array}$

$\begin{array}{llllll}5.49 & 0.53 & 0.95 & 0.03 & 1.89 & 0.52 \\ 2.80 & 0.60 & 1.10 & 0.06 & 1.82 & 0.52 \\ 1.40 & 0.63 & 1.30 & 0.16 & 1.70 & 0.52 \\ 0.77 & 0.68 & 1.57 & 0.26 & 1.63 & 0.50 \\ 0.47 & 0.66 & 1.69 & 0.32 & 1.62 & 0.45 \\ 0.29 & 0.80 & 1.87 & 0.25 & 1.61 & 0.51 \\ 4.00 & 0.53 & 0.94 & 0.03 & 1.88 & 0.52 \\ 2.11 & 0.60 & 1.14 & 0.11 & 1.88 & 0.48 \\ 0.98 & 0.67 & 1.56 & 0.27 & 1.68 & 0.47 \\ 0.54 & 0.68 & 1.67 & 0.32 & 1.60 & 0.48 \\ 0.34 & 0.80 & 1.79 & 0.26 & 1.62 & 0.52 \\ 0.27 & 0.96 & 1.76 & 0.06 & 1.93 & 0.49\end{array}$

Acutimitoceras intermedium (Schindewolf, 1923)

$\begin{array}{lrrrrrrrrrr}\text { MB.C.10206.1 } & 19.18 & 13.26 & 11.21 & 0.34 & 5.26 & 0.69 & 1.18 & 0.02 & 1.90 & 0.53 \\ & 10.42 & 7.97 & 5.89 & 0.50 & 2.68 & 0.76 & 1.35 & 0.05 & 1.81 & 0.55 \\ & 5.91 & 5.03 & 2.88 & 0.97 & 1.31 & 0.85 & 1.75 & 0.16 & 1.65 & 0.55 \\ & 3.59 & 3.08 & 1.48 & 1.10 & 0.75 & 0.86 & 2.08 & 0.31 & 1.60 & 0.49 \\ & 2.22 & 1.92 & 0.83 & 0.79 & 0.48 & 0.86 & 2.32 & 0.36 & 1.62 & 0.42 \\ \text { MB.C.10155.4 } & 1.43 & 1.19 & 0.52 & 0.50 & 0.31 & 0.83 & 2.30 & 0.35 & 1.62 & 0.41 \\ & 0.92 & 0.91 & 0.44 & 0.13 & 0.21 & 0.98 & 2.07 & 0.14 & 1.66 & 0.53 \\ & 15.66 & 10.44 & 8.91 & 0.82 & 4.95 & 0.67 & 1.17 & 0.05 & 2.14 & 0.44 \\ & 7.76 & 5.98 & 3.91 & 1.01 & 1.93 & 0.77 & 1.53 & 0.13 & 1.77 & 0.51 \\ & 4.47 & 3.61 & 1.99 & 1.04 & 1.01 & 0.81 & 1.82 & 0.23 & 1.67 & 0.49 \\ & 2.71 & 2.18 & 0.97 & 0.91 & 0.48 & 0.80 & 2.25 & 0.34 & 1.48 & 0.50 \\ & 1.79 & 1.33 & 0.65 & 0.64 & 0.37 & 0.74 & 2.06 & 0.36 & 1.58 & 0.43 \\ & 1.11 & 1.07 & 0.49 & 0.17 & 0.26 & 0.96 & 2.20 & 0.15 & 1.68 & 0.48\end{array}$




\begin{tabular}{lcccccccccc}
\hline & $\mathrm{dm}$ & ww & wh & uw & ah & ww/dm & ww/wh & uw/dm & WER & IZR \\
\hline MB.C.10216.1 & 13.68 & 9.25 & 7.80 & 0.52 & 3.84 & 0.68 & 1.19 & 0.04 & 1.93 & 0.51 \\
& 7.24 & 5.62 & 3.82 & 0.67 & 1.84 & 0.78 & 1.47 & 0.09 & 1.80 & 0.52 \\
& 4.10 & 3.43 & 1.91 & 0.78 & 0.99 & 0.84 & 1.80 & 0.19 & 1.73 & 0.48 \\
& 2.37 & 1.92 & 0.95 & 0.74 & 0.52 & 0.81 & 2.03 & 0.31 & 1.63 & 0.46 \\
& 1.47 & 1.17 & 0.55 & 0.37 & 0.33 & 0.80 & 2.12 & 0.25 & 1.65 & 0.41
\end{tabular}

Acutimitoceras depressum (Vöhringer, 1960)

$\begin{array}{lrrrrrrrrrr}\text { MB.C.10190.1 } & 12.80 & 10.33 & 7.29 & 0.31 & 3.36 & 0.81 & 1.42 & 0.02 & 1.84 & 0.54 \\ & 7.07 & 6.13 & 3.69 & 0.84 & 1.57 & 0.87 & 1.66 & 0.12 & 1.65 & 0.58 \\ & 4.27 & 3.73 & 2.10 & 0.82 & 1.02 & 0.87 & 1.78 & 0.19 & 1.73 & 0.51 \\ & 2.54 & 2.15 & 1.10 & 0.68 & 0.56 & 0.85 & 1.95 & 0.27 & 1.65 & 0.49 \\ \text { MB.C.10152.3 } & 1.53 & 1.29 & 0.62 & 0.35 & 0.36 & 0.84 & 2.09 & 0.23 & 1.71 & 0.42 \\ & 0.90 & 0.86 & 0.44 & 0.02 & 0.23 & 0.96 & 1.94 & 0.02 & 1.78 & 0.49 \\ & 12.14 & 9.42 & 6.48 & 0.88 & 2.74 & 0.78 & 1.45 & 0.07 & 1.67 & 0.58 \\ & 7.20 & 5.94 & 3.48 & 1.18 & 1.67 & 0.83 & 1.71 & 0.16 & 1.69 & 0.52 \\ & 4.32 & 3.58 & 1.92 & 0.99 & 0.95 & 0.83 & 1.86 & 0.23 & 1.64 & 0.51 \\ & 2.63 & 2.03 & 1.02 & 0.80 & 0.58 & 0.77 & 1.99 & 0.30 & 1.65 & 0.43 \\ & 1.61 & 1.09 & 0.57 & 0.53 & 0.35 & 0.68 & 1.90 & 0.33 & 1.64 & 0.39 \\ & 0.98 & 0.91 & 0.45 & 0.13 & 0.21 & 0.93 & 2.02 & 0.14 & 1.63 & 0.53\end{array}$

Acutimitoceras sarahae

\begin{tabular}{|c|c|c|c|c|c|c|c|c|c|c|}
\hline MB.C.10156.1 & 15.01 & 9.18 & 7.95 & 1.18 & 4.25 & 0.61 & 1.15 & 0.08 & 1.95 & 0.47 \\
\hline MB.C.10207.2 & 25.55 & 15.02 & 15.52 & 0.04 & - & 0.59 & - & 0.00 & - & - \\
\hline MB.C.10156.2 & 13.05 & 7.52 & 6.40 & 1.39 & 3.75 & 0.58 & 1.18 & 0.11 & 1.97 & 0.41 \\
\hline \multirow{6}{*}{ MB.C.10207.1 } & 21.61 & 12.38 & 12.34 & 0.58 & 6.13 & 0.57 & 1.00 & 0.03 & 1.95 & 0.50 \\
\hline & 11.06 & 6.85 & 5.57 & 1.68 & 2.73 & 0.62 & 1.23 & 0.15 & 1.76 & 0.51 \\
\hline & 6.43 & 3.30 & 2.58 & 2.23 & 1.46 & 0.51 & 1.28 & 0.35 & 1.67 & 0.43 \\
\hline & 3.95 & 1.60 & 1.05 & 2.05 & 0.79 & 0.40 & 1.53 & 0.52 & 1.56 & 0.25 \\
\hline & 2.44 & 0.97 & 0.64 & 1.31 & 0.52 & 0.40 & 1.52 & 0.54 & 1.61 & 0.18 \\
\hline & 1.57 & 0.73 & 0.40 & 0.71 & 0.31 & 0.46 & 1.81 & 0.45 & 1.55 & 0.23 \\
\hline \multirow{6}{*}{ MB.C.10156.5 } & 14.19 & 7.92 & 7.90 & 1.08 & 4.19 & 0.56 & 1.00 & 0.08 & 2.02 & 0.47 \\
\hline & 7.27 & 3.91 & 3.29 & 1.74 & 1.82 & 0.54 & 1.19 & 0.24 & 1.78 & 0.45 \\
\hline & 4.19 & 1.87 & 1.37 & 1.86 & 0.86 & 0.45 & 1.36 & 0.45 & 1.59 & 0.37 \\
\hline & 2.66 & 1.05 & 0.65 & 1.45 & 0.50 & 0.40 & 1.60 & 0.55 & 1.52 & 0.23 \\
\hline & 1.75 & 0.88 & 0.54 & 0.75 & 0.38 & 0.50 & 1.62 & 0.43 & 1.63 & 0.31 \\
\hline & 1.08 & 0.76 & 0.43 & 0.27 & 0.24 & 0.70 & 1.77 & 0.25 & 1.67 & 0.43 \\
\hline
\end{tabular}

Acutimitoceras mfisense Bockwinkel \& Ebbighausen, 2006

$\begin{array}{lrrrrrrrrrr}\text { MB.C.10157.2 } & 11.58 & 5.85 & 6.48 & 0.61 & 3.26 & 0.51 & 0.90 & 0.05 & 1.94 & 0.50 \\ \text { MB.C.10157.3 } & 10.16 & 5.14 & 5.69 & 0.52 & 2.88 & 0.51 & 0.90 & 0.05 & 1.95 & 0.49 \\ \text { MB.C.10157.1 } & 13.55 & 6.00 & 7.73 & 0.75 & 4.03 & 0.44 & 0.78 & 0.06 & 2.03 & 0.48 \\ & 6.91 & 3.46 & 3.31 & 1.49 & 1.70 & 0.50 & 1.05 & 0.22 & 1.76 & 0.49 \\ & 4.02 & 1.98 & 1.33 & 1.79 & 0.83 & 0.49 & 1.48 & 0.44 & 1.59 & 0.38 \\ & 2.51 & 1.24 & 0.69 & 1.29 & 0.52 & 0.49 & 1.79 & 0.51 & 1.59 & 0.25 \\ & 1.62 & 0.98 & 0.48 & 0.73 & 0.33 & 0.60 & 2.05 & 0.45 & 1.58 & 0.30\end{array}$

Acutimitoceras endoserpens $\mathrm{n}$. sp.

\begin{tabular}{|c|c|c|c|c|c|c|c|c|c|c|}
\hline MB.C.10153.1 & 12.93 & 6.23 & 6.44 & 1.97 & 3.67 & 0.48 & 0.97 & 0.15 & 1.95 & 0.43 \\
\hline MB.C.10215.1 & 13.78 & 7.62 & 7.51 & 1.18 & 3.71 & 0.55 & 1.01 & 0.09 & 1.87 & 0.51 \\
\hline МВ.C.10153.2 & 9.93 & 4.61 & 4.68 & 2.32 & 2.47 & 0.46 & 0.99 & 0.23 & 1.77 & 0.47 \\
\hline \multirow[t]{6}{*}{ MB.C.10153.3 } & 14.60 & 6.60 & 8.28 & 0.28 & 3.99 & 0.45 & 0.80 & 0.02 & 1.89 & 0.52 \\
\hline & 7.69 & 4.02 & 3.88 & 1.51 & 2.03 & 0.52 & 1.04 & 0.20 & 1.84 & 0.48 \\
\hline & 4.30 & 1.97 & 1.29 & 2.05 & 0.96 & 0.46 & 1.53 & 0.48 & 1.66 & 0.25 \\
\hline & 2.65 & 1.11 & 0.69 & 1.41 & 0.49 & 0.42 & 1.61 & 0.53 & 1.51 & 0.29 \\
\hline & 1.73 & 0.90 & 0.57 & 0.72 & 0.35 & 0.52 & 1.58 & 0.42 & 1.57 & 0.39 \\
\hline & 1.09 & 0.72 & 0.37 & 0.36 & 0.22 & 0.67 & 1.96 & 0.33 & 1.58 & 0.40 \\
\hline \multirow[t]{6}{*}{ MB.C.10191.2 } & 11.05 & 5.45 & 6.08 & 1.06 & 3.06 & 0.49 & 0.90 & 0.10 & 1.91 & 0.50 \\
\hline & 5.94 & 3.06 & 2.34 & 2.13 & 1.38 & 0.52 & 1.31 & 0.36 & 1.69 & 0.41 \\
\hline & 3.56 & 1.59 & 1.01 & 1.80 & 0.72 & 0.45 & 1.58 & 0.50 & 1.57 & 0.28 \\
\hline & 2.27 & 1.06 & 0.64 & 1.15 & 0.44 & 0.47 & 1.66 & 0.51 & 1.53 & 0.32 \\
\hline & 1.49 & 0.81 & 0.47 & 0.59 & 0.29 & 0.54 & 1.70 & 0.39 & 1.53 & 0.40 \\
\hline & 0.91 & 0.66 & 0.36 & 0.21 & 0.22 & 0.72 & 1.84 & 0.23 & 1.75 & 0.38 \\
\hline \multicolumn{11}{|c|}{ Acutimitoceras algeriense Ebbighausen, Bockwinkel \& Korn, 2004} \\
\hline MB.C.10228.1 & 87.22 & 39.75 & 50.06 & 0.49 & 23.39 & 0.46 & 0.79 & 0.01 & 1.87 & 0.53 \\
\hline МВ.C.10228.5 & 31.10 & 17.55 & 19.69 & 0.30 & 8.63 & 0.56 & 0.89 & 0.01 & 1.92 & 0.56 \\
\hline MB.C.10151 & 14.65 & 8.89 & 8.05 & 0.77 & 3.97 & 0.61 & 1.10 & 0.05 & 1.88 & 0.51 \\
\hline \multirow[t]{2}{*}{ MB.C.10228.2 } & 64.48 & 27.36 & 37.49 & 0.44 & 17.58 & 0.42 & 0.73 & 0.01 & 1.89 & 0.53 \\
\hline & 34.36 & 17.11 & 19.65 & 0.68 & 9.97 & 0.50 & 0.87 & 0.02 & 1.98 & 0.49 \\
\hline
\end{tabular}




\begin{tabular}{rrrrrrrrrrr}
\hline & \multicolumn{1}{c}{$\mathrm{dm}$} & \multicolumn{1}{c}{ ww } & \multicolumn{1}{c}{ wh } & uw & ah & ww/dm & ww/wh & uw/dm & WER & IZR \\
\hline MB.C.10228.3 & 19.53 & 9.00 & 11.51 & 0.36 & 6.63 & 0.46 & 0.78 & 0.02 & - & 0.42 \\
& 8.31 & 5.27 & 4.69 & 0.54 & 2.58 & 0.63 & 1.12 & 0.07 & 2.11 & 0.45 \\
& 4.07 & 2.94 & 2.04 & 0.58 & 1.17 & 0.72 & 1.44 & 0.14 & 1.96 & 0.43 \\
& 2.09 & 1.65 & 0.92 & 0.52 & 0.55 & 0.79 & 1.79 & 0.25 & 1.85 & 0.40 \\
& 1.16 & 1.04 & 0.42 & 0.37 & 0.29 & 0.90 & 2.49 & 0.32 & 1.79 & 0.30
\end{tabular}

Acutimitoceras sp. A

\begin{tabular}{|c|c|c|c|c|c|c|c|c|c|c|}
\hline MB.C.10223.3 & 70.57 & 37.60 & 41.31 & 1.09 & 21.68 & 0.53 & 0.91 & 0.02 & 2.08 & 0.48 \\
\hline MB.C.10223.8 & 44.17 & 24.05 & 22.64 & 1.59 & 14.13 & 0.54 & 1.06 & 0.04 & 2.16 & 0.38 \\
\hline MB.C.10223.9 & 35.19 & 20.94 & 19.97 & 1.68 & 11.12 & 0.60 & 1.05 & 0.05 & 2.14 & 0.44 \\
\hline MB.C.10223.2 & 30.20 & 19.65 & 17.68 & 1.24 & 8.77 & 0.65 & 1.11 & 0.04 & 1.99 & 0.50 \\
\hline MB.C.10223.7 & 20.84 & 13.16 & 10.52 & 1.17 & 6.18 & 0.63 & 1.25 & 0.06 & 2.02 & 0.41 \\
\hline MB.C.10223.6 & 18.84 & 11.46 & 10.34 & 1.05 & 5.93 & 0.61 & 1.11 & 0.06 & 2.13 & 0.43 \\
\hline MB.C.10223.4 & 17.47 & 9.55 & 10.11 & 0.28 & 4.83 & 0.55 & 0.94 & 0.02 & 1.91 & 0.52 \\
\hline & 9.10 & 5.74 & 5.28 & 0.32 & 2.52 & 0.63 & 1.09 & 0.04 & 1.91 & 0.52 \\
\hline
\end{tabular}

Acutimitoceras sp. B

$\begin{array}{lrrrrrrrrrr}\text { Acutimitoceras } \text { sp. B B } & & & & & & & & & \\ \text { MB.C.10209.2 } & 28.03 & 22.93 & 15.43 & 1.02 & 6.85 & 0.82 & 1.49 & 0.04 & 1.75 & 0.56 \\ & 16.15 & 12.42 & 8.54 & 1.38 & 3.55 & 0.77 & 1.45 & 0.09 & 1.64 & 0.58 \\ & 9.78 & 6.29 & 4.86 & 1.83 & 2.26 & 0.64 & 1.29 & 0.19 & 1.69 & 0.54 \\ & 5.73 & 3.12 & 2.22 & 2.03 & 1.24 & 0.55 & 1.40 & 0.35 & 1.63 & 0.44 \\ & 3.55 & 1.66 & 1.09 & 1.69 & 0.73 & 0.47 & 1.52 & 0.48 & 1.59 & 0.33 \\ & 2.29 & 1.02 & 0.62 & 1.09 & 0.44 & 0.44 & 1.65 & 0.48 & 1.54 & 0.28 \\ \text { MB.C.10209.1 } & 1.45 & 0.93 & 0.57 & 0.37 & 0.35 & 0.64 & 1.65 & 0.25 & 1.74 & 0.38 \\ & 25.17 & 21.39 & 14.32 & 0.65 & 6.20 & 0.85 & 1.49 & 0.03 & 1.76 & 0.57 \\ & 14.38 & 12.26 & 7.75 & 1.33 & 3.47 & 0.85 & 1.58 & 0.09 & 1.74 & 0.55 \\ & 8.45 & 6.69 & 4.30 & 1.17 & 1.82 & 0.79 & 1.56 & 0.14 & 1.62 & 0.58 \\ & 5.24 & 3.34 & 2.24 & 1.46 & 1.16 & 0.64 & 1.50 & 0.28 & 1.65 & 0.48 \\ & 3.13 & 1.57 & 1.05 & 1.38 & 0.69 & 0.50 & 1.50 & 0.44 & 1.64 & 0.35 \\ & 1.95 & 0.99 & 0.57 & 0.89 & 0.41 & 0.51 & 1.72 & 0.46 & 1.60 & 0.29\end{array}$

Acutimitoceras posterum Bockwinkel \& Ebbighausen, 2006

\begin{tabular}{|c|c|c|c|c|c|c|c|c|c|c|}
\hline MB.C.10229 & 10.73 & 7.20 & 6.00 & 0.55 & 2.91 & 0.67 & 1.20 & 0.05 & 1.88 & 0.51 \\
\hline & 5.90 & 3.98 & 2.92 & 1.14 & 1.50 & 0.67 & 1.36 & 0.19 & 1.80 & 0.49 \\
\hline & 3.30 & 2.07 & 1.19 & 1.27 & 0.74 & 0.63 & 1.74 & 0.39 & 1.66 & 0.38 \\
\hline & 2.04 & 1.36 & 0.70 & 0.74 & 0.44 & 0.66 & 1.94 & 0.36 & 1.63 & 0.37 \\
\hline & 1.25 & 1.01 & 0.46 & 0.33 & 0.29 & 0.81 & 2.20 & 0.26 & 1.69 & 0.37 \\
\hline Acutimitoceras & iconstri & 1. sp. & & & & & & & & \\
\hline MB.C.10218 & 11.53 & 6.23 & 6.17 & 0.40 & 3.20 & 0.54 & 1.01 & 0.03 & 1.91 & 0.48 \\
\hline Costimitoceras & amar $\mathrm{n}$ & & & & & & & & & \\
\hline MB.C.10159.1 & 11.70 & 5.10 & 6.83 & 0.00 & 3.24 & 0.44 & 0,75 & 0.00 & 1.91 & 0.52 \\
\hline MB.C.10159.8 & 10.31 & 5.50 & 5.80 & 0.32 & 3.12 & 0.53 & 0.95 & 0.03 & 2.05 & 0.44 \\
\hline MB.C.10159.7 & 9.04 & 4.94 & 5.29 & 0.38 & 2.55 & 0.55 & 0.93 & 0.04 & 1.94 & 0.52 \\
\hline MB.C.10159.5 & 4.95 & 2.96 & 2.67 & 0.24 & 1.39 & 0.60 & 1.11 & 0.05 & 1.93 & 0.48 \\
\hline MB.C.10159.4 & 2.70 & 1.87 & 1.52 & 0.12 & 0.81 & 0.69 & 1.23 & 0.04 & 2.04 & 0.47 \\
\hline MB.C.10159.3 & 8.90 & 4.62 & 4.96 & 0.25 & 2.31 & 0.52 & 0.93 & 0.03 & 1.83 & 0.53 \\
\hline & 4.74 & 2.81 & 2.61 & 0.23 & 1.26 & 0.59 & 1.08 & 0.05 & 1.85 & 0.52 \\
\hline & 2.56 & 1.80 & 1.42 & 0.19 & 0.67 & 0.70 & 1.26 & 0.07 & 1.84 & 0.53 \\
\hline & 1.42 & 1.14 & 0.64 & 0.36 & 0.31 & 0.81 & 1.80 & 0.26 & 1.65 & 0.51 \\
\hline MB.C.10197.2 & 6.57 & 3.81 & 3.57 & 0.15 & 1.62 & 0.58 & 1.06 & 0.02 & 1.76 & 0.55 \\
\hline & 3.59 & 2.26 & 1.93 & 0.17 & 0.95 & 0.63 & 1.17 & 0.05 & 1.84 & 0.51 \\
\hline & 1.93 & 1.38 & 0.95 & 0.29 & 0.48 & 0.72 & 1.45 & 0.15 & 1.77 & 0.50 \\
\hline & 1.13 & 0.82 & 0.42 & 0.32 & 0.27 & 0.73 & 1.95 & 0.28 & 1.73 & 0.36 \\
\hline Hasselbachia $g$ & $a$ Ebbi & $\mathrm{n}, \mathrm{Bo}$ & kel \& & , 2004 & & & & & & \\
\hline MB.C.10234.2 & 8.77 & 4.17 & 3.10 & 2.9 & 1.46 & 0.48 & 1.35 & 0.33 & 1.44 & 0.53 \\
\hline MB.C.10179 & 15.36 & 7.08 & 6.72 & 3.30 & 2.84 & 0.46 & 1.05 & 0.21 & 1.51 & 0.58 \\
\hline & 10.17 & 5.19 & 4.17 & 2.68 & 1.83 & 0.51 & 1.24 & 0.26 & 1.49 & 0.56 \\
\hline & 6.82 & 4.04 & 2.53 & 2.32 & 1.16 & 0.59 & 1.60 & 0.34 & 1.45 & 0.54 \\
\hline & 4.67 & 3.03 & 1.60 & 1.80 & 0.81 & 0.65 & 1.90 & 0.39 & 1.46 & 0.49 \\
\hline & 3.19 & 2.36 & 1.03 & 1.38 & 0.54 & 0.74 & 2.29 & 0.43 & 1.45 & 0.47 \\
\hline & 2.24 & 1.72 & 0.71 & 0.95 & 0.37 & 0.77 & 2.43 & 0.42 & 1.44 & 0.47 \\
\hline & 1.53 & 1.27 & 0.56 & 0.48 & 0.30 & 0.83 & 2.27 & 0.31 & 1.55 & 0.46 \\
\hline Hasselbachia a & sp. & & & & & & & & & \\
\hline MB.C.10233.1 & 9.18 & 5.70 & 3.24 & 3.41 & 1.46 & 0.62 & 1.76 & 0.37 & 1.41 & 0.55 \\
\hline MB.C.10233.2 & 16.93 & 9.52 & 5.7 & 6.36 & 3.11 & 0.56 & 1.67 & 0.38 & 1.50 & 0.45 \\
\hline MB.C.10233.4 & 10.12 & 5.57 & 3.11 & 4.09 & 1.69 & 0.55 & 1.79 & 0.40 & 1.44 & 0.46 \\
\hline
\end{tabular}




\begin{tabular}{|c|c|c|c|c|c|c|c|c|c|c|}
\hline & $\mathrm{dm}$ & ww & wh & uw & ah & $\mathrm{ww} / \mathrm{dm}$ & ww/wh & $\mathrm{uw} / \mathrm{dm}$ & WER & IZR \\
\hline MB.C.10233.3 & 8.48 & 5.10 & 3.12 & 2.77 & 1.64 & 0.60 & 1.63 & 0.33 & 1.54 & 0.47 \\
\hline \multirow[t]{7}{*}{ MB.C. 10233.5} & 12.65 & 7.27 & 5.08 & 3.71 & 2.20 & 0.58 & 1.43 & 0.29 & 1.46 & 0.57 \\
\hline & 8.63 & 5.70 & 3.08 & 3.10 & 1.54 & 0.66 & 1.85 & 0.36 & 1.48 & 0.50 \\
\hline & 5.80 & 4.13 & 1.84 & 2.43 & 0.99 & 0.71 & 2.25 & 0.42 & 1.46 & 0.46 \\
\hline & 3.93 & 2.98 & 1.23 & 1.70 & 0.71 & 0.76 & 2.43 & 0.43 & 1.49 & 0.42 \\
\hline & 2.64 & 2.14 & 0.86 & 1.07 & 0.49 & 0.81 & 2.48 & 0.41 & 1.50 & 0.44 \\
\hline & 1.74 & 1.48 & 0.62 & 0.60 & 0.36 & 0.85 & 2.39 & 0.34 & 1.58 & 0.43 \\
\hline & 1.09 & 0.93 & 0.42 & 0.27 & 0.27 & 0.85 & 2.21 & 0.25 & 1.77 & 0.36 \\
\hline \multirow[t]{7}{*}{ MB.C.10233.6 } & 10.73 & 6.31 & 3.58 & 4.16 & 1.74 & 0.59 & 1.76 & 0.39 & 1.42 & 0.51 \\
\hline & 7.60 & 5.08 & 2.43 & 3.07 & 1.27 & 0.67 & 2.09 & 0.40 & 1.44 & 0.48 \\
\hline & 5.20 & 3.86 & 1.72 & 2.08 & 0.88 & 0.74 & 2.25 & 0.40 & 1.45 & 0.49 \\
\hline & 3.55 & 2.74 & 1.15 & 1.45 & 0.66 & 0.77 & 2.38 & 0.41 & 1.50 & 0.43 \\
\hline & 2.35 & 1.94 & 0.75 & 0.97 & 0.41 & 0.82 & 2.58 & 0.41 & 1.47 & 0.45 \\
\hline & 1.59 & 1.30 & 0.58 & 0.50 & 0.33 & 0.82 & 2.23 & 0.32 & 1.60 & 0.43 \\
\hline & 0.96 & 0.86 & 0.43 & 0.15 & 0.23 & 0.90 & 2.01 & 0.15 & 1.71 & 0.47 \\
\hline \multicolumn{11}{|l|}{ Hasselbachia sp. } \\
\hline \multirow[t]{5}{*}{ MB.C.10235.3 } & 8.05 & 5.56 & 3.54 & 1.85 & 1.73 & 0.69 & 1.57 & 0.23 & 1.62 & 0.51 \\
\hline & 4.98 & 3.86 & 1.90 & 1.65 & 1.00 & 0.78 & 2.03 & 0.33 & 1.57 & 0.47 \\
\hline & 3.18 & 2.52 & 1.14 & 1.16 & 0.63 & 0.79 & 2.21 & 0.37 & 1.56 & 0.45 \\
\hline & 2.03 & 1.69 & 0.72 & 0.72 & 0.43 & 0.83 & 2.33 & 0.35 & 1.62 & 0.40 \\
\hline & 1.23 & 1.08 & 0.50 & 0.33 & 0.30 & 0.88 & 2.15 & 0.27 & 1.74 & 0.41 \\
\hline \multirow[t]{3}{*}{ MB.C.10235.2 } & 11.88 & 7.06 & 5.63 & 1.98 & 2.41 & 0.59 & 1.25 & 0.17 & 1.58 & 0.57 \\
\hline & 7.56 & 5.08 & 3.24 & 1.86 & 1.55 & 0.67 & 1.57 & 0.25 & 1.58 & 0.52 \\
\hline & 4.74 & 3.56 & 1.90 & 1.51 & 1.01 & 0.75 & 1.88 & 0.32 & 1.62 & 0.47 \\
\hline \multicolumn{11}{|c|}{ Kornia citrus n. sp. } \\
\hline MB.C.10165.4 & 16.31 & 14.70 & 8.02 & 0.62 & 3.63 & 0.90 & 1.83 & 0.04 & 1.65 & 0.55 \\
\hline \multirow[t]{4}{*}{ MB.C.10202.1 } & 8.18 & 9.31 & 4.32 & 0.38 & 1.68 & 1.14 & 2.15 & 0.05 & 1.58 & 0.61 \\
\hline & 5.16 & 6.09 & 2.60 & 0.51 & 0.98 & 1.18 & 2.35 & 0.10 & 1.52 & 0.62 \\
\hline & 3.51 & 3.76 & 1.48 & 0.66 & 0.59 & 1.07 & 2.55 & 0.19 & 1.44 & 0.60 \\
\hline & 2.37 & 2.16 & 0.96 & 0.57 & 0.39 & 0.91 & 2.24 & 0.24 & 1.43 & 0.60 \\
\hline \multirow{5}{*}{ MB.C.10165.2 } & 7.07 & 8.80 & 3.70 & 0.62 & 1.42 & 1.25 & 2.38 & 0.09 & 1.57 & 0.61 \\
\hline & 4.63 & 6.11 & 2.32 & 0.64 & 0.86 & 1.32 & 2.64 & 0.14 & 1.51 & 0.63 \\
\hline & 3.10 & 3.62 & 1.31 & 0.76 & 0.57 & 1.17 & 2.76 & 0.25 & 1.50 & 0.56 \\
\hline & 2.05 & 2.00 & 0.79 & 0.63 & 0.36 & 0.98 & 2.54 & 0.31 & 1.47 & 0.55 \\
\hline & 1.36 & 1.06 & 0.52 & 0.35 & 0.29 & 0.78 & 2.05 & 0.26 & 1.61 & 0.44 \\
\hline \multicolumn{11}{|c|}{ Imitoceras oxydentale Bockwinkel \& Ebbighausen, 2006} \\
\hline MB.C.10162.1 & 16.66 & 7.57 & 9.09 & 0.78 & 5.41 & 0.45 & 0.83 & 0.05 & 2.19 & 0.41 \\
\hline \multirow[t]{6}{*}{ MB.C. 10200.1} & 16.13 & 7.28 & 9.24 & 0.33 & 4.58 & 0.45 & 0.79 & 0.02 & 1.95 & 0.50 \\
\hline & 8.32 & 4.18 & 4.66 & 0.41 & 2.24 & 0.50 & 0.90 & 0.05 & 1.87 & 0.52 \\
\hline & 4.51 & 2.25 & 2.26 & 0.72 & 1.17 & 0.50 & 0.99 & 0.16 & 1.82 & 0.48 \\
\hline & 2.50 & 1.33 & 1.12 & 0.69 & 0.64 & 0.53 & 1.18 & 0.28 & 1.80 & 0.43 \\
\hline & 1.43 & 0.97 & 0.56 & 0.41 & 0.29 & 0.68 & 1.73 & 0.29 & 1.56 & 0.49 \\
\hline & 0.88 & 0.77 & 0.43 & 0.16 & 0.24 & 0.87 & 1.77 & 0.19 & 1.88 & 0.45 \\
\hline MB.C.10162.5 & 13.09 & 5.95 & 7.62 & 0.12 & 3.91 & 0.45 & 0.78 & 0.01 & 2.03 & 0.49 \\
\hline & 6.50 & 3.05 & 3.56 & 0.55 & 1.77 & 0.47 & 0.86 & 0.08 & 1.89 & 0.50 \\
\hline & 3.48 & 1.78 & 1.57 & 0.87 & 0.89 & 0.51 & 1.13 & 0.25 & 1.81 & 0.43 \\
\hline & 1.92 & 1.12 & 0.72 & 0.65 & 0.48 & 0.58 & 1.54 & 0.34 & 1.78 & 0.34 \\
\hline Imitoceras sp. & & & & & & & & & & \\
\hline MB.C.10187.2 & 38.42 & 15.86 & 22.82 & 0.58 & 12.04 & 0.41 & 0.70 & 0.02 & 2.12 & 0.47 \\
\hline & 17.90 & 9.60 & 10.69 & 0.24 & 5.83 & 0.54 & 0.90 & 0.01 & 2.20 & 0.45 \\
\hline & 7.91 & 5.12 & 4.68 & 0.33 & 2.53 & 0.65 & 1.09 & 0.04 & 2.16 & 0.46 \\
\hline & 3.78 & 2.84 & 1.96 & 0.55 & 0.96 & 0.75 & 1.45 & 0.15 & 1.80 & 0.51 \\
\hline & 2.10 & 1.58 & 0.99 & 0.40 & 0.55 & 0.75 & 1.60 & 0.19 & 1.84 & 0.44 \\
\hline & 1.17 & 1.10 & 0.54 & 0.15 & 0.30 & 0.94 & 2.02 & 0.12 & 1.83 & 0.44 \\
\hline MB.C.10187.4 & 21.99 & 11.47 & 12.84 & 0.29 & 6.98 & 0.52 & 0.89 & 0.01 & 2.15 & 0.46 \\
\hline & 10.12 & 6.36 & 5.94 & 0.43 & 3.13 & 0.63 & 1.07 & 0.04 & 2.10 & 0.47 \\
\hline & 4.85 & 3.58 & 2.44 & 0.84 & 1.35 & 0.74 & 1.47 & 0.17 & 1.92 & 0.45 \\
\hline & 2.65 & 2.00 & 1.16 & 0.59 & 0.70 & 0.75 & 1.72 & 0.22 & 1.84 & 0.40 \\
\hline & 1.48 & 1.24 & 0.65 & 0.28 & 0.38 & 0.84 & 1.90 & 0.19 & 1.81 & 0.42 \\
\hline Gattendorfia ja & linae $\mathrm{Eb}$ & hausen, & ckwink & Korn, & & & & & & \\
\hline MB.C.10232.3 & 52.21 & 32.75 & 23.04 & 10.27 & 13.1 & 0.63 & 1.42 & 0.20 & 1.78 & 0.43 \\
\hline MB.C.10232.4 & 53.52 & 31.58 & 24.06 & 13.43 & 12.81 & 0.59 & 1.31 & 0.25 & 1.73 & 0.47 \\
\hline & 33.12 & 23.82 & 12.45 & 11.61 & 6.65 & 0.72 & 1.91 & 0.35 & 1.57 & 0.47 \\
\hline & 21.45 & 15.37 & 6.90 & 9.11 & 4.04 & 0.72 & 2.23 & 0.42 & 1.52 & 0.41 \\
\hline & 14.03 & 9.93 & 3.96 & 7.04 & 2.49 & 0.71 & 2.51 & 0.50 & 1.48 & 0.37 \\
\hline & 9.35 & 5.60 & 2.37 & 5.24 & 1.69 & 0.60 & 2.36 & 0.56 & 1.49 & 0.29 \\
\hline
\end{tabular}




\begin{tabular}{|c|c|c|c|c|c|c|c|c|c|c|}
\hline & $\mathrm{dm}$ & ww & wh & uw & $\mathrm{ah}$ & $\mathrm{ww} / \mathrm{dm}$ & ww/wh & $\mathrm{uw} / \mathrm{dm}$ & WER & IZR \\
\hline \multirow{10}{*}{ MB.C.10177.2 } & 6.37 & 3.16 & 1.40 & 3.85 & 1.12 & 0.50 & 2.26 & 0.60 & 1.47 & 0.20 \\
\hline & 4.38 & 2.13 & 0.93 & 2.68 & 0.73 & 0.49 & 2.30 & 0.61 & 1.44 & 0.21 \\
\hline & 3.04 & 1.56 & 0.74 & 1.59 & 0.54 & 0.51 & 2.12 & 0.52 & 1.48 & 0.27 \\
\hline & 2.01 & 1.19 & 0.63 & 0.86 & 0.42 & 0.59 & 1.89 & 0.43 & 1.60 & 0.33 \\
\hline & 1.27 & 0.99 & 0.50 & 0.30 & 0.30 & 0.78 & 1.99 & 0.23 & 1.71 & 0.40 \\
\hline & 8.57 & 4.76 & 2.19 & 4.46 & 1.43 & 0.55 & 2.17 & 0.52 & 1.44 & 0.35 \\
\hline & 5.70 & 3.38 & 1.53 & 2.98 & 1.11 & 0.59 & 2.20 & 0.52 & 1.54 & 0.28 \\
\hline & 3.70 & 2.05 & 0.93 & 2.01 & 0.71 & 0.56 & 2.20 & 0.54 & 1.53 & 0.24 \\
\hline & 2.43 & 1.46 & 0.64 & 1.24 & 0.47 & 0.60 & 2.27 & 0.51 & 1.54 & 0.27 \\
\hline & 1.59 & 1.12 & 0.49 & 0.52 & 0.34 & 0.71 & 2.28 & 0.33 & 1.62 & 0.31 \\
\hline
\end{tabular}

Gattendorfia debouaaensis (Bockwinkel \& Ebbighausen, 2006)

\begin{tabular}{|c|c|c|c|c|c|c|c|c|c|c|}
\hline MB.C.10230.1 & 64.17 & 46.26 & 21.45 & 16.77 & 11.91 & 0.72 & 2.16 & 0.26 & 1.51 & 0.44 \\
\hline MB.C.10175.4 & 41.19 & 33.91 & 14.92 & 13.25 & 9.90 & 0.82 & 2.27 & 0.32 & 1.73 & 0.34 \\
\hline \multirow[t]{3}{*}{ MB.C.10175.1 } & 43.68 & 34.89 & 17.54 & 12.48 & 9.33 & 0.80 & 1.99 & 0.29 & 1.62 & 0.47 \\
\hline & 26.69 & 21.46 & 10.41 & 8.81 & 5.95 & 0.80 & 2.06 & 0.33 & 1.66 & 0.43 \\
\hline & 16.47 & 12.55 & 5.72 & 6.37 & 3.41 & 0.76 & 2.19 & 0.39 & 1.59 & 0.40 \\
\hline \multirow[t]{3}{*}{ MB.C.10230.3 } & 40.06 & 32.14 & 15.99 & 12.19 & 8.52 & 0.80 & 2.01 & 0.30 & 1.61 & 0.47 \\
\hline & 24.59 & 20.86 & 9.06 & 9.00 & 4.91 & 0.85 & 2.30 & 0.37 & 1.56 & 0.46 \\
\hline & 15.63 & 12.23 & 5.39 & 6.85 & 3.04 & 0.78 & 2.27 & 0.44 & 1.54 & 0.43 \\
\hline \multirow[t]{7}{*}{ MB.C.10230.4 } & 18.28 & 13.73 & 7.16 & 6.29 & 4.32 & 0.75 & 1.92 & 0.34 & 1.71 & 0.40 \\
\hline & 10.93 & 7.52 & 3.43 & 4.90 & 2.27 & 0.69 & 2.19 & 0.45 & 1.59 & 0.34 \\
\hline & 6.96 & 4.38 & 1.97 & 3.43 & 1.44 & 0.63 & 2.22 & 0.49 & 1.59 & 0.27 \\
\hline & 4.39 & 2.44 & 1.13 & 2.37 & 0.84 & 0.56 & 2.15 & 0.54 & 1.52 & 0.26 \\
\hline & 2.91 & 1.56 & 0.73 & 1.57 & 0.54 & 0.53 & 2.14 & 0.54 & 1.50 & 0.26 \\
\hline & 1.91 & 1.11 & 0.51 & 0.91 & 0.34 & 0.58 & 2.16 & 0.48 & 1.47 & 0.35 \\
\hline & 1.23 & 1.03 & 0.48 & 0.23 & 0.32 & 0.83 & 2.15 & 0.18 & 1.80 & 0.34 \\
\hline
\end{tabular}

Gattendorfia lhceni $\mathrm{n} . \mathrm{sp}$.

MB.C.10225.1 $\quad 44.21$

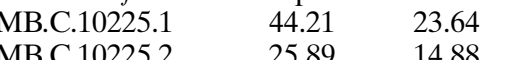

$\begin{array}{llr}\text { MB.C.10225.5 } & 17.58 & 10.45\end{array}$

MB.C.10225.6 $\quad 11.11 \quad 7.05$

$\begin{array}{lll}21.44 & 8.39 & 12.02\end{array}$

$\begin{array}{lll}11.17 & 5.45 & 7.17\end{array}$

$\begin{array}{lll}8.46 & 3.65 & 4.42\end{array}$

$\begin{array}{lll}5.11 & 3.17 & 2.70\end{array}$

$\begin{array}{ll}1.82 & 3.27\end{array}$

$1.05 \quad 2.10$

MB.C.10225.7

$3.95 \quad 1.63$

2.10
4.42

$1.65 \quad 3.66$

$6.53 \quad 3.38$

$4.23 \quad 1.92$

$2.88 \quad 1.32$

$0.89 \quad 2.57$

$0.64-1.68$

$1.94 \quad 1.06$

0.50

0.93

$0.51 \quad 0.27$

1.42

0.82

2.53

1.31

0.73

0.52

0.36

0.22

$0.53 \quad 1.10$

$0.57 \quad 1.33$

$\begin{array}{ll}0.59 & 1.24\end{array}$

$0.63 \quad 1.38$

$\begin{array}{ll}0.49 & 1.74\end{array}$

$0.41 \quad 1.55$

$0.61 \quad 1.73$

$0.52 \quad 2.05$

$0.45 \quad 2.16$

$0.46 \quad 2.07$

$0.55 \quad 2.13$

Gattendorfia gisae n. sp.

$\begin{array}{lrrrr}\text { MB.C.10176.1 } & 61.72 & 47.65 & 27.08 & 16.39 \\ & 30.24 & 25.65 & 12.81 & 8.73 \\ \text { MB.C.10176.2 } & 15.32 & 12.71 & 6.12 & 4.87 \\ & 44.45 & 37.33 & 19.01 & 12.09 \\ & 22.86 & 18.25 & 9.26 & 7.20 \\ \text { MB.C.10231.1 } & 12.43 & 9.15 & 4.50 & 4.62 \\ & 20.21 & 15.93 & 7.97 & 6.38 \\ & 11.00 & 7.98 & 4.04 & 4.02 \\ & 6.37 & 4.38 & 2.25 & 2.34 \\ & 3.84 & 2.58 & 1.46 & 1.28\end{array}$

18.53

8.92

4.03

12.32

6.21

2.89

5.40

2.68

1.42

0.85

2.06

$\begin{array}{lll}0.19 & 1.89 & 0.44\end{array}$

$\begin{array}{lll}0.21 & 1.91 & 0.36\end{array}$

$\begin{array}{lll}0.21 & 1.78 & 0.48\end{array}$

$\begin{array}{lll}0.29 & 1.75 & 0.47\end{array}$

$\begin{array}{lll}0.51 & 1.64 & 0.22\end{array}$

$\begin{array}{lll}0.53 & 1.59 & 0.22\end{array}$

$\begin{array}{lll}0.41 & 1.70 & 0.34\end{array}$

$\begin{array}{lll}0.56 & 1.57 & 0.20\end{array}$

$\begin{array}{lll}0.61 & 1.46 & 0.18\end{array}$

$\begin{array}{lll}0.58 & 1.49 & 0.19\end{array}$

$\begin{array}{lll}0.48 & 1.50 & 0.28\end{array}$

$\begin{array}{lll}0.22 & 1.47 & 0.57\end{array}$

Kazakhstania nitida Bockwinkel \& Ebbighausen, 2006

\begin{tabular}{|c|c|c|c|c|c|c|c|c|c|c|}
\hline MB.C.10164.2 & 4.49 & 1.80 & 1.03 & 2.59 & 0.80 & 0.40 & 1.74 & 0.58 & 1.48 & 0.22 \\
\hline & 3.07 & 1.20 & 0.77 & 1.69 & 0.59 & 0.39 & 1.57 & 0.55 & 1.54 & 0.23 \\
\hline & 2.02 & 0.90 & 0.48 & 1.06 & 0.41 & 0.45 & 1.87 & 0.52 & 1.58 & 0.15 \\
\hline & 1.25 & 0.80 & 0.41 & 0.39 & 0.27 & 0.64 & 1.93 & 0.31 & 1.64 & 0.33 \\
\hline МB.C.10164.3 & 4.11 & 1.59 & 0.92 & 2.42 & 0.73 & 0.39 & 1.73 & 0.59 & 1.48 & 0.20 \\
\hline & 2.77 & 1.09 & 0.66 & 1.54 & 0.51 & 0.39 & 1.65 & 0.56 & 1.51 & 0.22 \\
\hline & 1.84 & 0.88 & 0.54 & 0.83 & 0.36 & 0.48 & 1.63 & 0.45 & 1.55 & 0.33 \\
\hline & 1.16 & 0.76 & 0.41 & 0.32 & 0.27 & 0.66 & 1.86 & 0.28 & 1.70 & 0.34 \\
\hline Eocanites simp & ockwin & Ebbi & en, 20 & & & & & & & \\
\hline MB.C.10160.1 & 11.05 & 4.23 & 3.29 & 5.36 & 2.80 & 0.38 & 1.29 & 0.49 & 1.79 & 0.15 \\
\hline MB.C.10160.2 & 7.48 & 2.87 & 2.10 & 3.77 & 1.80 & 0.38 & 1.37 & 0.50 & 1.73 & 0.14 \\
\hline & 4.29 & 1.81 & 1.26 & 2.06 & 1.09 & 0.42 & 1.43 & 0.48 & 1.80 & 0.14 \\
\hline & 2.41 & 1.17 & 0.71 & 1.09 & 0.58 & 0.48 & 1.64 & 0.45 & 1.74 & 0.18 \\
\hline & 1.38 & 0.86 & 0.47 & 0.53 & 0.35 & 0.62 & 1.81 & 0.38 & 1.78 & 0.27 \\
\hline & 0.77 & 0.76 & 0.38 & 0.08 & 0.23 & 0.98 & 1.99 & 0.10 & 2.04 & 0.39 \\
\hline
\end{tabular}




\begin{tabular}{|c|c|c|c|c|c|c|c|c|c|c|}
\hline & $\mathrm{dm}$ & ww & wh & uw & ah & $\mathrm{ww} / \mathrm{dm}$ & ww/wh & $\mathrm{uw} / \mathrm{dm}$ & WER & IZR \\
\hline \multicolumn{11}{|c|}{ Kahlacanites mariae Ebbighausen, Bockwinkel \& Korn, 2004} \\
\hline MB.C.10181.1 & 20.33 & 6.96 & 8.36 & 5.97 & 5.68 & 0.34 & 0.83 & 0.29 & 1.93 & 0.32 \\
\hline \multirow[t]{4}{*}{ MB.C.10236.2 } & 21.02 & 6.15 & 7.91 & 7.33 & 5.52 & 0.29 & 0.78 & 0.35 & 1.84 & 0.30 \\
\hline & 11.33 & 4.01 & 3.98 & 4.51 & 3.04 & 0.35 & 1.01 & 0.40 & 1.87 & 0.24 \\
\hline & 6.01 & 2.47 & 1.93 & 2.75 & 1.61 & 0.41 & 1.28 & 0.46 & 1.86 & 0.17 \\
\hline & 3.26 & 1.42 & 0.96 & 1.59 & 0.83 & 0.44 & 1.48 & 0.49 & 1.80 & 0.13 \\
\hline \multirow[t]{6}{*}{ MB.C.10236.3 } & 15.92 & 5.34 & 6.04 & 5.63 & 4.04 & 0.34 & 0.89 & 0.35 & 1.80 & 0.33 \\
\hline & 8.86 & 3.62 & 2.99 & 3.78 & 2.21 & 0.41 & 1.21 & 0.43 & 1.78 & 0.26 \\
\hline & 5.08 & 2.12 & 1.51 & 2.50 & 1.17 & 0.42 & 1.40 & 0.49 & 1.69 & 0.22 \\
\hline & 2.99 & 1.31 & 0.80 & 1.54 & 0.68 & 0.44 & 1.64 & 0.51 & 1.68 & 0.15 \\
\hline & 1.77 & 0.99 & 0.56 & 0.77 & 0.44 & 0.56 & 1.76 & 0.44 & 1.77 & 0.22 \\
\hline & 0.99 & 0.73 & 0.36 & 0.26 & 0.27 & 0.73 & 1.99 & 0.26 & 1.89 & 0.26 \\
\hline
\end{tabular}

Kahlacanites meyendorffi Ebbighausen, Bockwinkel \& Korn, 2004

$\begin{array}{lllllllllll}\text { MB.C.10174 } & 14.78 & 4.45 & 4.83 & 6.43 & 4.56 & 0.30 & 0.92 & 0.44 & 2.09 & 0.06 \\ \text { MB.C.10237 } & 14.02 & 5.19 & 4.71 & 6.10 & 3.90 & 0.37 & 1.10 & 0.44 & 1.92 & 0.17\end{array}$

